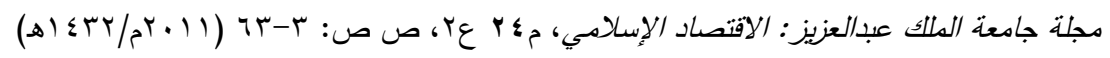
DOI: 10.4197 / Islec. 24-2.1

\title{
التمويل الإسلامي في بريطانيا: الفرص والتحديات(")
}

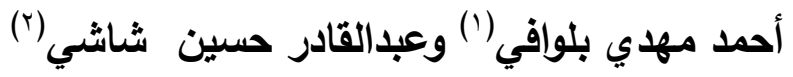

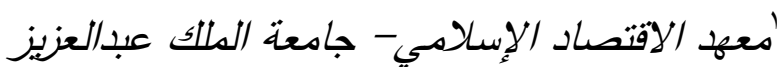

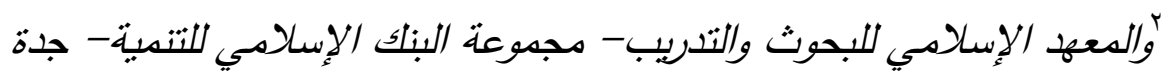 \\ المدلكة العربية السعودية \\ ambelouafi@kau.edu.sa achachi@isdb.org
}

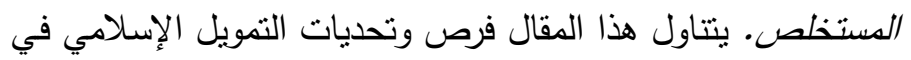

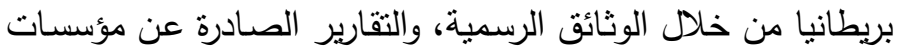

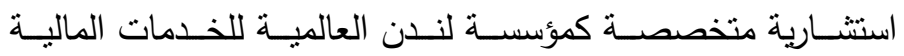

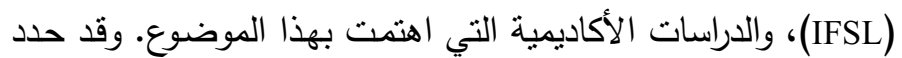

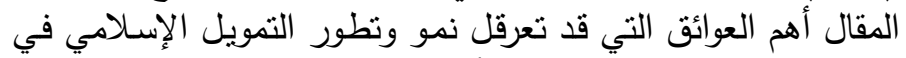

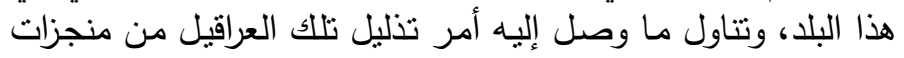

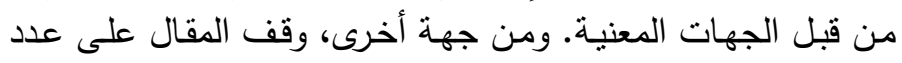
من الفرص التي قد تتيحها السوق البريطانية للتمويل الإسلامي. وني.

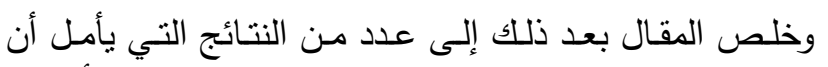

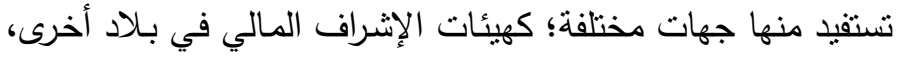

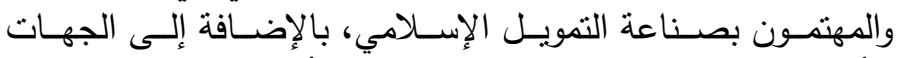

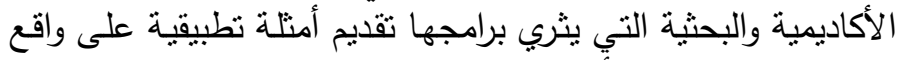
التمويل الإسلامي في أُماكن مختلفة.

الكلمات المفتاحية: التمويل الإسلامي، الإشراف المالي، بريطانيا.

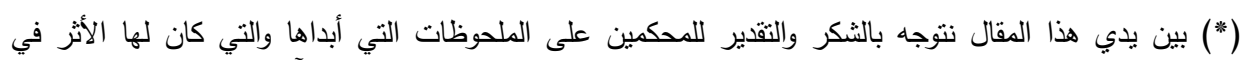

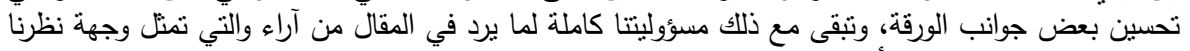
وليس وجهة نظر المحكمين أو غيرهم. 


\section{-}

اتسع نطاق عمل المؤسسات التمويلية الإسـامية بشكل لافت في السنين الأخيرة، مما

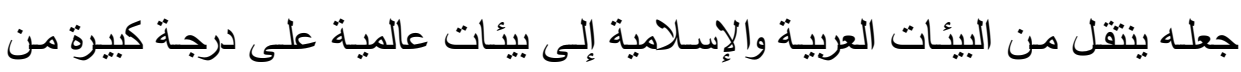
المنافسة والنظور • ومن الدول التي لها حضور بارز في هذا المجال المملكة المتحدة؛ فهي الدولة الوحيدة من بين الدول الغربية التي منحت ترخيصًا لإنشـاء خمسة مصـارف إسلامية حتى الآن، كما أنها سمحت لعدد من المصارف التقليدية بتقديم خدمات مالية "متوافقة مع أحكام الثريعة الإسلامية"، وحكومتها تسعى لأن تكون مركزًا عالميًا للتمويل الإسلامي خارج البلاد العربية والإسلامية.

هذا الواقـع الذي عليـه الحال في بريطانيا فرض عددًا من التسـاؤلات التي يحاول هذا المقال معالجتها بالدراسة والتحليل؛ تساؤلات من قبيل: ما حقيقة تطور

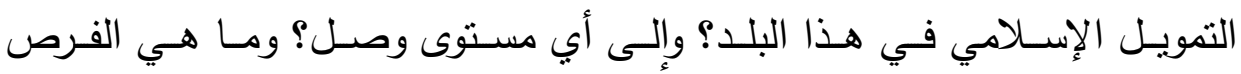
والتحديات التي يفرضـها تواجد هذا النوع من التمويل في بيئة مالية عالميـة على لي مستوى عال من التطور والتعقيد؟

إن المقال يُسـلط الضـوء على التسـاؤلات السـابقة بغرض الوقوف على أهم

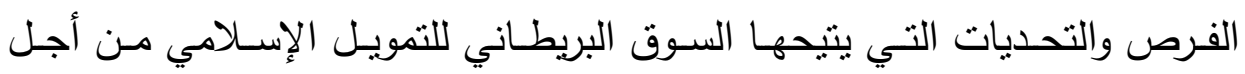
التوصل لبعض النتائج ذات الأهمية العلمية والعملية. وقد انتظم المقال في الأقسام التالية: الدراسات السابقة، والمنهجية، وتطور التمويل الإسـامي في بريطانيا، ثم الفرص والتحديات، وأخيرًا الخلاصـة والنتائج. وبين يدي هذا المقال نـود التتبيه على النقاط التالية: - ملية

1- نعت المصارف أو المنتجات بالإسـلامية في السوق البريطانية لا يعني إصدار حكم شرعي عليها من طرفنا بقدر ما هو نقل للواقع كما يوصف بـه من قبل أصحابه أو المهتمين به. 
r- من المصـادر التي اعتمد عليها البحث بثنكل رئيس الوثائق الصـادرة عن الحكومة البربطانية باعتبارها المحرك الأساسي لهذا الملف؛ وقد اتضـح ذلك من خـلال الفعاليات التي قامت بها أو شـاركت فيها الحكومـة منذ عام ... بـم وإلى حد الآن. إن الاعتمـاد على هذه الوثائق لا يعني بحـال اتفاقنا الكامل مـع الإجراءات التي تقوم بها الحكومـة البربطانيـة، كمـا لا يعني أن مـا قامت بـه هو لهو الطريقة المنلى للتعامل مع مسألة إدراج التمويل الإسلامي في القوانين التقليدية. r- استخدام بعض المصطلحات مثل المرابحة، والإجارة، والوكالة، أو غيرهـا لوصف بعض المنتجات أو المعاملات كما ورد في الدراسـات والوثائق أو النشـرات التعريفيـة الصـادرة عـن المؤسسـات المقدمـة للخدمات التمويليـة المتوافقـة مـع أحكـام الثريعة لا يعني بالضرورة أن هذه المضامين متفقة مع ما هو سائد في كتب الفقه. ع- اختيار التجربـة البربطانية وخصـها بالدراسـة والتمحيص جاء بنـاء على عدد من الاعتبارات من أهمها التطور الحاصل في نمو التمويل الإسلامي في هذا البلد مع قلة، إن لم يكن انعدام، الدراسات العلمية باللغة العربية التي تقوم بدراسـة وتحليل هذا التطور بكل موضوعية، تتقل الواقع كما هو بكل سلبياته وإيجابياته، ومـن ثم تضـع الاستتناجات والتطورات بنـاء على ذلك وليس بنـاء على مواقف "تهويلية" أو "تهوبنية" مسبقة. ومن جهة أخرى فإن التطور الحاصل في السوق البريطاني - كما سيتضح من خلال المعطيات- لا يماثله التطور الحاصل في أي بلد متقدم آخر وخاصـة البلدان الأوربية. كما أن عدم تتاولنا لتجارب أخرى مثل الفرنسية لعلمنا بوجود دراسات مشابهة يقوم بها زملاء لنا، ولعله بعد استكمال هذه الدراسـات يستحسن المقارنـة بينها لاستخلاص بعض التوجهات الإستراتيجية التي قد تفيد عملية انتشار التمويل الإسلامي في البيئات غير العربية والإسلامية بطريقة مخطط لها وليس بطريقة عفوية أو ارتجالية. 


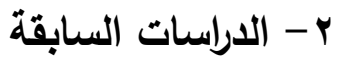

فيما يلي استعراض للاراسـات ذات الصـلة المباشـرة بالموضوع الذي يتطرق إلبه هذا المقال: - n

ا- دراسـة رودنـي ولسـن عـام 999 ام (Wilson, 1999) ")، والتي جـاءت تحت عنوان "تحديات وفرص المصـرفية والتموبـل الإسـلامي في الغرب: تجربـة

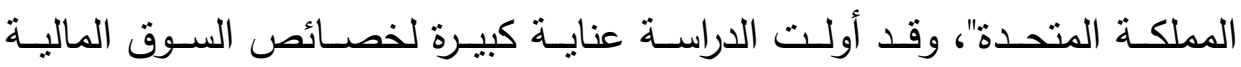
البربطانية، وتطور التمويل الإسـامي فيها منذ بداية الثمانينيات وحتى التسعينيات من القرن الماضي، أما جانب الفرص والتحديات فقد ذُكر بشكل مقتضب في ثتايا

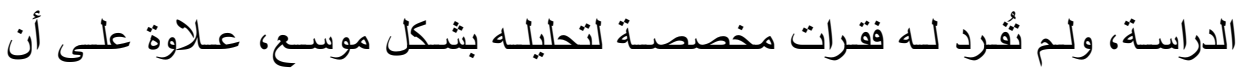
معطيات الدراسة توقفت عند حدود تسعينيات القرن الماضي. r- دراسة هومايون دار عام r +. (Dar, 2002) (r) عن شراء المنازل في بربطانيا بواسطة عقود التمويـل الإسـلامي، والدراسـة كمـا هو واضـح من عنوانها ومن مضدونها كذللك، أنها تتتاول جزئية واحدة تتعلق بتمويل المنازل بالنسبة لأفراد الجالية المسلمة؛ حجم هذه السوق والعوائق التي تحول دون الإقبال عليها بشكل كبير من قبل أفراد الجاليـة، وخلصـت الدراسـة إلى أن من أهم العوائق في ذلك "فثل" القائمين على الصناعة في التسويق بتقديم المعلومات الكافية عن المنتجات التي يعرضـونها، وإذا مـا حدث تحسن في هذا الأمـر، فـإن الدراسـة تخلص إلى إمكانيـة تطور سوق "الرهن العقاري الإسـامي" في بربطانيا بشكل كبير • وهكذا، يلاحظ أن البحث ركز على جزئية واحدة وعلى ما ارتبط بها من عوائق.

Wilson, R. (1999) "Challenges and Opportunities for Islamic Banking and Finance ( I) in the West: The United Kingdom Experience".

Dar, H.A. (2002) "Islamic Housing Financing in the United Kingdom: Problems, (Y) Challenges and Prospects". 


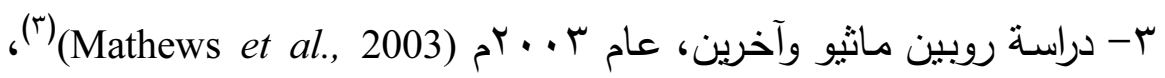
عن التطورات الأخيرة في سـوق العقار المـول مـن خـلال المنتجـات الإسـلامية. والدراسة شبيهة في موضوعها بالتي سبقتها حيث إنها تركز على التموبل العقاري المقدم من قبل المؤسسات التمويلية الإسـامية مع رصد آخر التطورات في ذللك. وقد تتاولت الدراسة منتجات المرابحة والإجارة، وقامت بعرض تجربـة التمويل الإسـامي مـن خـلال التمويـل الخُلقي أو الأخلاقيـاتي (Ethical finance)(ع) الذي بـات يحتل اهتمامًا منزايدًا في أوساط بريطانيا وغيرها من الدول الأوروبية، وانتهت الدراسـة إلى الى بعض النتائج تتعلق بدور التمويل الإسـلامي بشكل خاص، والخُلقي بشكل عام في

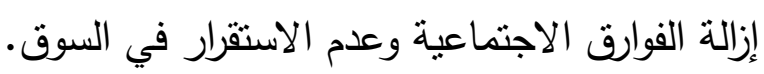

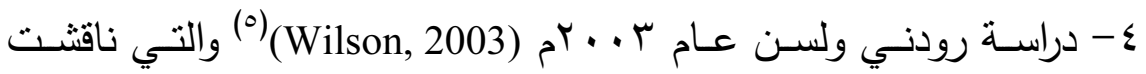

قضايا تتعلق بأسواق المال والمنتجات والخدمات المالية الإسـالية بشكل عام، ولم تذكر التحديات فيما يتعلق بالسوق البربطانية إلا عرضًا. ومن ثم فقد لامس نطاق اهتمام الدراسة موضوع البحث بطريق عام وغير مباشر ، ولم يكن تتبعًا للتحديات الخاصة بالبيئة البريطانية مع التذقيق والتفصيل في ذلك.

Mathews, R., Tlemsani, I., and Siddiqui, A. (2003) "Recent Developments in the (r) Market for Islamic Mortgages: Theory and Practice".

(ع) لفت نظرنا أحد المحكمين، مشكورًا، إلى ضرورة الإشارة إلى أن الأدبيات الغربية تفرق بين لفظتي (ethical) و (moral)؛ وقد اقترح الإشارة إلى الأول بالخُلقي وكان زميلنا الدكتور بلعباس قد تتاول هذه المسألة بالنسبة للتمويل الإسلامي واستخدم لفظة القائم على الإلى الأخلاقيات أو الأخلاقياتي، أما الثاني (moral) فإنه لا إشكال في ترجمته إلى الأخلاق. ومرد هذه التفرقة إلى عدد من العوامل منها؛ البعد الديني، والمصدر ، والنسبية والإطلاق. وبناء عليه فإننا عبرنا في هذا المقال عن لفظة (ethical) بالخُلقي ليس من باب الترجيح

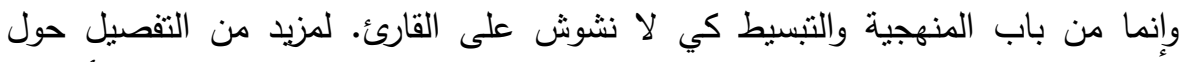
الموضوع يراجع: عبدالرزاق سعيد بلعباس ( • • rrم) التموبل الإسالامي بين الأخلاق

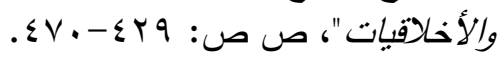

Wilson, R.J.A. (2003) "Regulatory Challenges posed by Islamic Capital Market (0) Products and Services". 


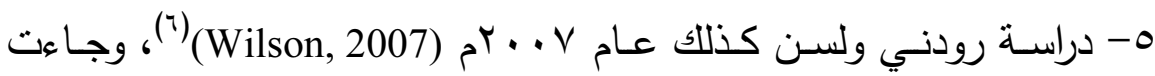

بعنوان "التمويل الإسلامي في أوروبا"، وهي دراسـة يغلب عليها الجانب العمومي،

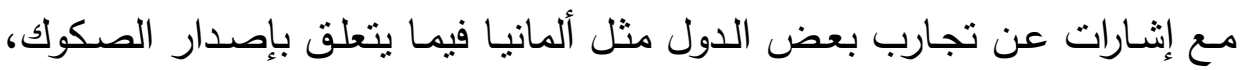
وبربطانيا فيما يتعلق بالترخيص للمصارف الإسلامية والتقليدية لتقديم خدمات مالية "متوافقة مـع أحكام الشـريعة الإسـلامية"، وكذا دراسـة الحكومـة البريطانيـة لمسألة إصـدار صـكوك سيادية (Sovereign Sukuk) إسـلامية، مـع الإشـارة إلى العوامـل التي جعلت بربطانيا تتقدم على نظيراتها الأوروبية في هذا المجال، كما أن الدراسـة أشارت إلى حساسية الموضوع بالنسبة للأوروبيين؛ حيث يعتبره البعض (اليمين)

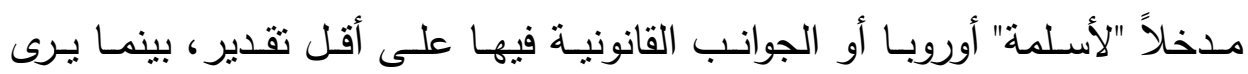
البعض الآخر ومنهم الأسـتاذ ولسـن (Wilson) على أن تقديم خدمات إسـلامية متوافقة مـع أحكام الشريعة يجب أن ينظر إليه على أنه وسيلة لتوسيع الخيارات التهات

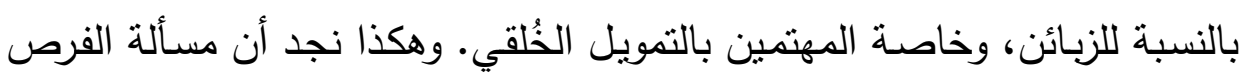

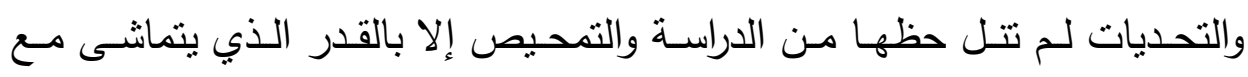
الطبيعة العامة للارراسة.

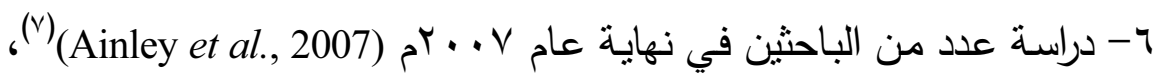
وجاءت بعنوان "التمويل الإسـامي في المملكة المتحدة: التقنين والتحديات" والتي نشرتها سلطة الخدمات المالية (Financial Services Authority)، ومن خـلا

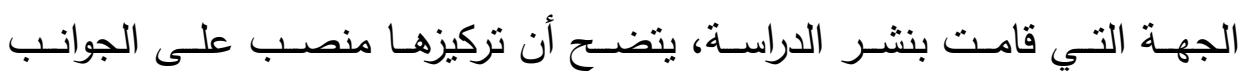
النشـريعية والقانونيـة التي تعترض سبيل إقامـة مؤسسـات ماليـة إسـلامية مـع ذكر سـبل التغلـب عليهـا مـن خـلال تجربـة السـلطة في التـرخيص للبنـك الإسـلامي ولي

Wilson, R. J.A. (2007) "Islamic Finance in Europe".

Ainley M.L; Mashayekhi A.; Hicks R.; Rahman A. and Ravalia A. (2007)

"Islamic Finance in the UK: Regulation and Challenges". 
البربطـاني. وقد تعرضـت الدراسـة بشـكل مختصـر لتطور التمويـل الإسـلامي في بريطانيا، مـع تعـداد بعض العواملـ التي تقف خلف ذلك، ولا شـك في أن هذه الدراسـة تمثل أحـد المصـادر الهامـة في موضـوع البحـث فيمـا بتعلق بالتحديات القانونية والتشريعية.

V- دراســة وسـيم لانجـا (Langah, 2008)، وهـي رســالة ماجسـتير بعنـوان "المصرفية الإسـامية في بريطانيا: الفرص والتحديات" والتي نوفتث في أكتوبر عام

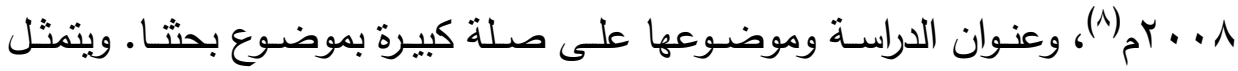
الجانـب الإيجـابي فيها في إجـراء تسـع مقابلات شخصية مـع أطـراف ذات علاقـة بالتمويل الإسلامي في بربطانيا، إلا أن عليها بعض الملاحظات؛ من ذلك على سبيل المثال عدم الدقة في بعض المـواطن، كالقول: بـأن خدمات التموبـل الإسـالامي لـم

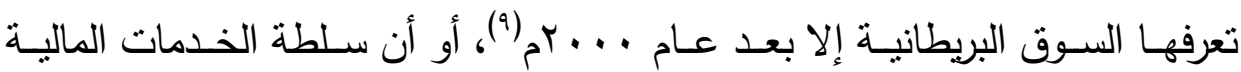
البريطانيـة (FSA) أوصـت (Recommended) بالتمويـل الإسـلامي (·) ') أو الحديث عن تحقق الثرعية بالنسبة لمعاملات المؤسسات التمويلية الإسلامية بوجود هيئة رقابة بعدد معين (')'، أو وصف التمويل الثخصي القائم على التورق بالنظرية ( Personal (loan based on the theory of Tawarruq في تتاول الفرص والتحديات مع الوقوف على آخر ما جرى من نطورات خاصة بعد

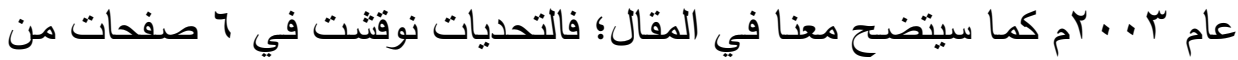
البحث، أمـا الفرص فلم تذكر إلا عرضًا، ومنها كذلك أن مراجعة الأدبيات كانت

Langah, W. A. (2008) "Islamic Banking in the United Kingdom: Opportunities and ( $)$ Challenges", MSc Dissertation, Kingston Business School, Kingston University, October 2008. 
عودة لمصـادر عامـة في التمويـل الإسـلامي ولم تكن مصـادر ذات صـلة مباشـرة بالموضوع كالتي أوردناها في مسـنا الأدبي هذا، ولهذا السبب خلت الرسـالة من

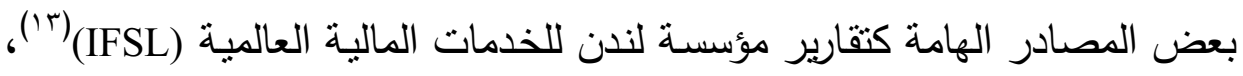
والتي حلت محلها مؤسسة (TheCityUK) للقيام بذات الأغراض وذلك منذ يونيو

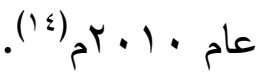

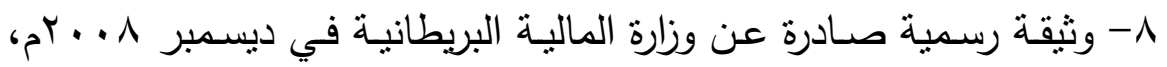
وحملت عنوان "تطور التمويل الإسلامي في المملكة المتحدة: وجهة نظر الحكومة البريطانيـة" (HM Treasury, 2008)(10)، وهي دراسـة كمـا هو واضـح من عنوانها ومحتواها تركز الطرح فيها على الدور الذي يقوم بـه أحد الأطراف الأساسيين في هذا الملف؛ ألا وهو الحكومـة البريطانيـة. وقد رصدت الوثيقة عددًا من العوائق التي قد تحول دون تطور التموبـل الإسـلامي في سـوق المـال البربطانبـة، والدور الذي قامت وتقوم بـه الحكومة في هذا الثـأن، كما أن الوثيقة تضمنت الأهداف التي تسعى الحكومة البربطانية إلى تحقيقها من خلال فسح المجال لهذا النمط من التمويل والمؤسسات القائمة على أساسـه، ولا شك في أن ما تضمنته الوثيقة يمثل أحد المصادر الهامة التي اعتمدت عليها دراستتا.

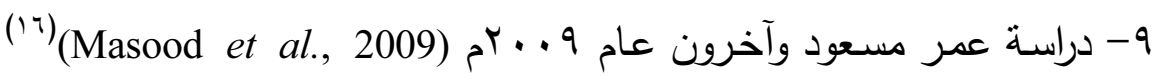

عن دور التمويل الإسـلامي في قطاع السكن في المملكة المتحدة، تتـاول الدراسـة هذا الموضـوع بغرض الوقوف على عدد مـن الحقائق منهـا دور هيئات الرقابـة الشرعية، والحوكمة في عمل المصـارف الإسـلامية التي تزاول عملها في المملكة International Financial Services London (IFSL).

TheCityUK (2011) "Islamic Finance May 2011", p. 2.

HM Treasury (2008) "Development of Islamic Finance in the UK: Government's (10) Perspective".

Masood, Omar, Chichti Jamel E., Mansour Walid, Amin Qazi Awais (2009) (1 7 )

"Role of Islamic mortgage in UK". 
المتحدة، ومنهـا كذللك معرفـة هـل عمل المصـارف الإســلامبة قائم على مبـادئ الاقتصاد الإسـامي، أم أنه مجرد تقليد ومحاكاة للتمويل التقليدي؟ وهكذا، نلاحظ أن هذه الدراسـة تركز على عنصـر مـن عناصـر التمويـل الإســلامي، وهـو ذالك

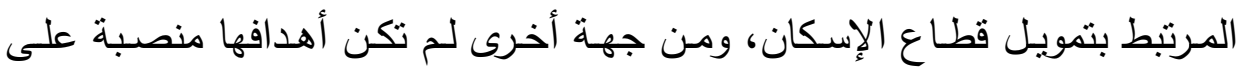
تحديد الفرص والتحديات بقدر ما كان متوجهًا لأبعاد أخرى لها أهميتها الكبرى فيما هيط الإنا يتعلق بتطور التمويل في بريطانيا.

مـن خـلال مـا سـبق استعراضـهـ مـن أدبيـات يمكن الخلوص إلى أن المقال يحاول الإضـافة عن الدراسـات السـابقة بتتاول آخر التطورات التي عرفها التموبل الإسـامي في السـنوات الأخيرة والتي تشـمل سـوات الأزمـة الماليـة الخانقة التي عانى منها الاقتصاد العالمي ولا يزال، وكذا تتاول جوانب لم تتطرق إلبها الدراسات السابقة أو التوسع والإضـافة في جوانب تطرقت إليها تلك الدراسات بشكل لا يفي بغرض إعطاء صورة كافية عن حقيقة التحدي أو الفرصة وماذا أنجز بشأنه. ومن جهة أخرى فإنه (في حدود علمنا) يعد المقال أول دراسـة علمية من نوعها تصدر باللغة العربية في الموضوع.

\section{ب- المنهمبة}

استخدمنا في هذا المقال المنهج الاستقرائي والوصف التحليلي، وذلك بتتاول

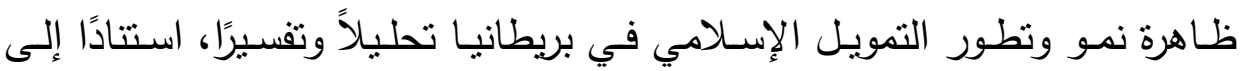
الخطابات والتقارير والمحاضر الرسمية الواردة عن سلطة الخدمات المالية (FSA)؛ ووزارة الماليـة (Treasury)، ومؤسسـة لنـدن العالميـة للخـدمات الماليـة (IFSL)؛ المكلفة بتعزيز تتافية حي المال في لندن، كما تمت الاستفادة من تقارير وأوراق

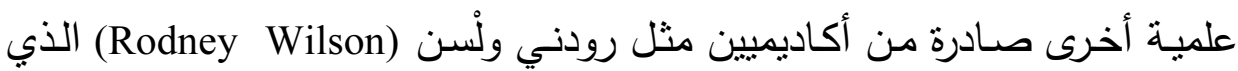
يعتبر من أكثر الثخصيات إنتاجـا واهتمامًا بموضوع التموبل الإسـلامي، وكذلك بعض الرسائل العلمية التي تتاولت هذا الموضوع، وذلك بغرض الوقوف على واقع 
التمويل الإسلامي ببريطانيا في الفترة الراهنة، والفرص المتاحة والتحديات القائمة،

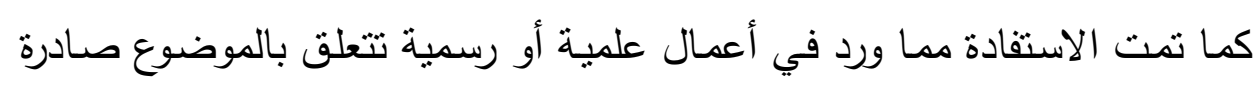

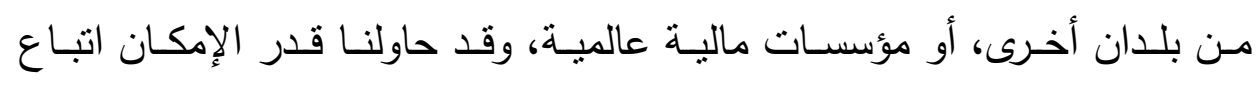
الخطوات الثالية عند مناقثة التحديات:

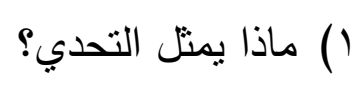

r) ماذا أنجز بشأنه من قبل الأطراف ذات الصلة خاصة الحكومة؟

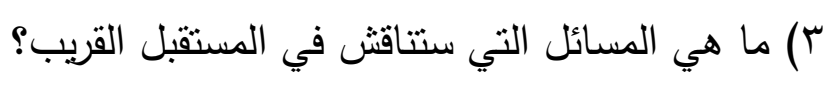

\section{؛ - تطور التمويل الإسلامي في بريطانيا}

تعـود تجربـة التمويـل الإســلاهي في السـوق الماليـة البريطانيـة إلـى أواخـر

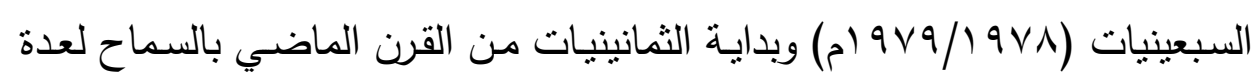

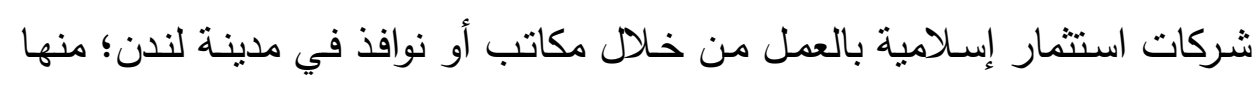

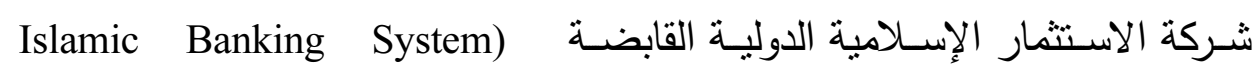
(International Holding )، وبيت التمويل الإنسلامي (Islamic Finance House)

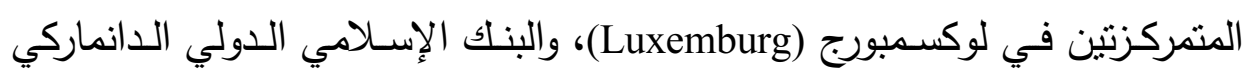
وكذلك شركة تكافل لوكسمبرج (Islamic Bank International of Denmark)

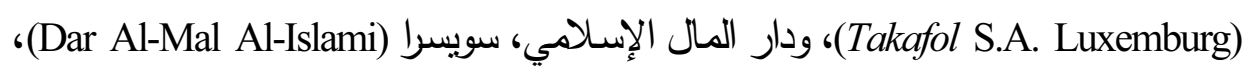

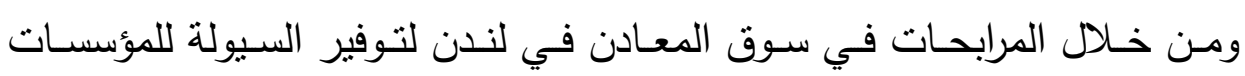

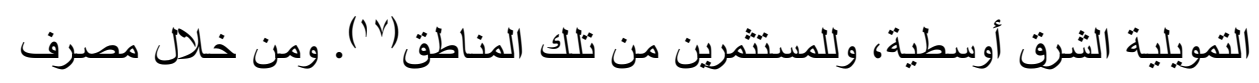

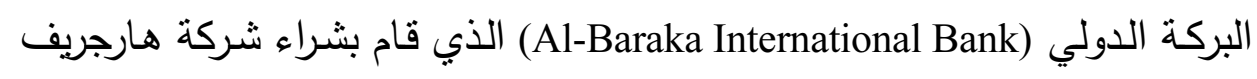

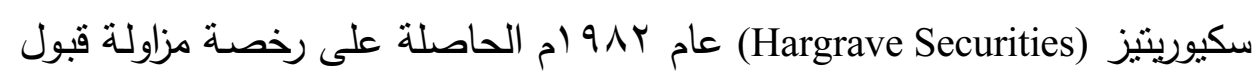

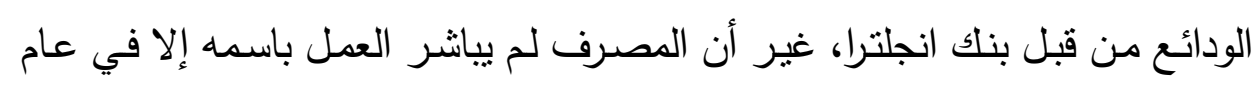
Ainley, M., et al., (2007) "Islamic Finance in the UK: Regulation and Challenges", p. 6. ( I V) 


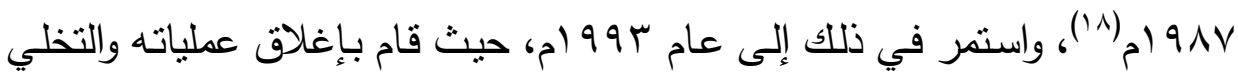
عن الرخصة التي منحت له من مصرف انجلترا-البنك المركزي البربطاني - بناء على قانون المصارف لعام 9 \ ام (Banking Act 1987)، وذلك بعد أن شدد بنك انجلترا عملياته الرقابيـة على المصـارف الأجنبيـة إثر انهيـار مصـرف الاعتمـاد والتجـارة الدولي (BCCI) عام المو (م.

وقد استمرت مجموعة البركة في العمل كثركة استثمارية بعد إعادة ترتيب

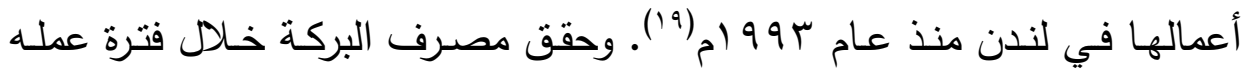
تطورات هائلة، حيث إنها استطاع توسيع قاعدة المتعـاملين معسه من زبـائن زوار قدموا من الخليج بشكل رئيس إلى زبائن محليين من أفراد الجالية المسلمة، وقد تمثل ذلك في عدد الفروع مـن ا إلى ب في لندن، وفي فتح فرع في مدينـة برمنجهام؛ المدينـة الثانيـة بعد لندن مـن حيـث عدد السكان، وبهذا تطور حجم

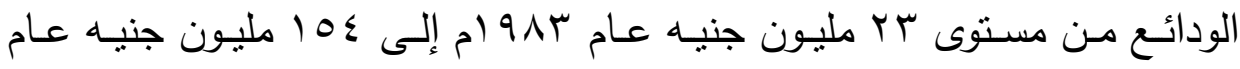
199 (م، كما أن المصرف حقق نتائج مالية جيدة خلال فترة عمله، وبعد انتهاء العمل قام بإعادة أموال المودعين بدون إثكالات أو عراقيل تذكر (·r). وإلى جانب مصرف البركة الدولي، الذي كان يعمل كمصرف تجزئة إسلامي (Retail Islamic Bank) منكامل كانت هناك مصارف ومؤسسات تمويلية عالمية تقدم خدمات مالية إسلامية عبر نوافذ مخصصة لذلك منذ عام سر9 ام. ومع حلول عام 9 ام عرف السوق البريطاني نطورًا من نوع آخر نمنل في قيام المصرف المتحد الأهلي الكويتي (UAB) بإنشاء وحدة تابعة له عرفت بالمنزل لتقديم تمويلات للجالية المسلمة لشراء المنازل (Manzil)

Wilson, R. (1999) "Challenges and Opportunities for Islamic Banking and ( $1 \mathrm{\Lambda}$ ) Finance in the West: The United Kingdom Experience", p. 426. 
خلال برنامجي المرابحة (Murabaha Plan)، والإجارة (Ijara Plan)، ثم تبعه في ذلك مصرف اتش اس بي سي (HSBC) عام r. . بام، ومؤسسة البراق التابعة لمصرف إي بي سي العالمي (ABC International)('⿳) ثم السماح في عام ع . . rم بإنشاء أول مصرف تجزئة إسلامي، وهو المصرف الإسلامي البريطاني (Islamic Bank of Britain) وهي: بنك الاستثمار الإسلاهي الأوروبي (The European Islamic Investment Bank)، وبنك لندن والثرق الأوسط (Bank of London and Middle East)، وبنك غيت هاوس (Gatehouse Bank)، وبيت التمويل الأوروبي (European Finance House)، وشركة السلام للتأمين الحلال (Salaam Halal Insurance). ولمعرفة حجم التطورات الأخيرة التي وصل إليها التمويل الإسـامي في هذا البلد بمكن ذكر المؤشرات التالية:

- - عـد المؤسسـات والنوافــ التمويليـة الإسـلامية: بلـنغ عدد المؤسسـات التمويليـة الإســلامية المصـرح لهـا بتقـديم خـدمات متوافقـة مـع أحكـام الثـربعة الإسـامية ستة مؤسسات (خمسـة مصسارف(rr) وشركة تكافل (تأمين) واحدة) (rr). أما المؤسسات التقليدية التي تقدم خدمات تمويلية متوافقة مع الثربعة فيقدر عددها

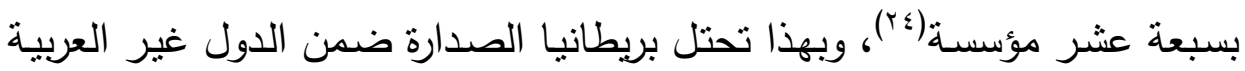
والإسلامية في هذا المجال، الثكل (1) التالي يوضح ذلك.

Leach, K. (2009) "Islamic Banking Developments in the Domestic UK Market", p.13. ( $\left.Y^{\prime}\right)$ (Yr) لمزيد معلومات حول هذه المصارف؛ كتاريخ النشأة أو غيره يراجع الملحق (1) في ذللك. (Y) Raza, M.F. (2008) "The European Opportunity", p. 44. ( $(r)$

IFSL (2010) "Islamic Finance 2010", p.3. ( $\Upsilon$ 纟) 


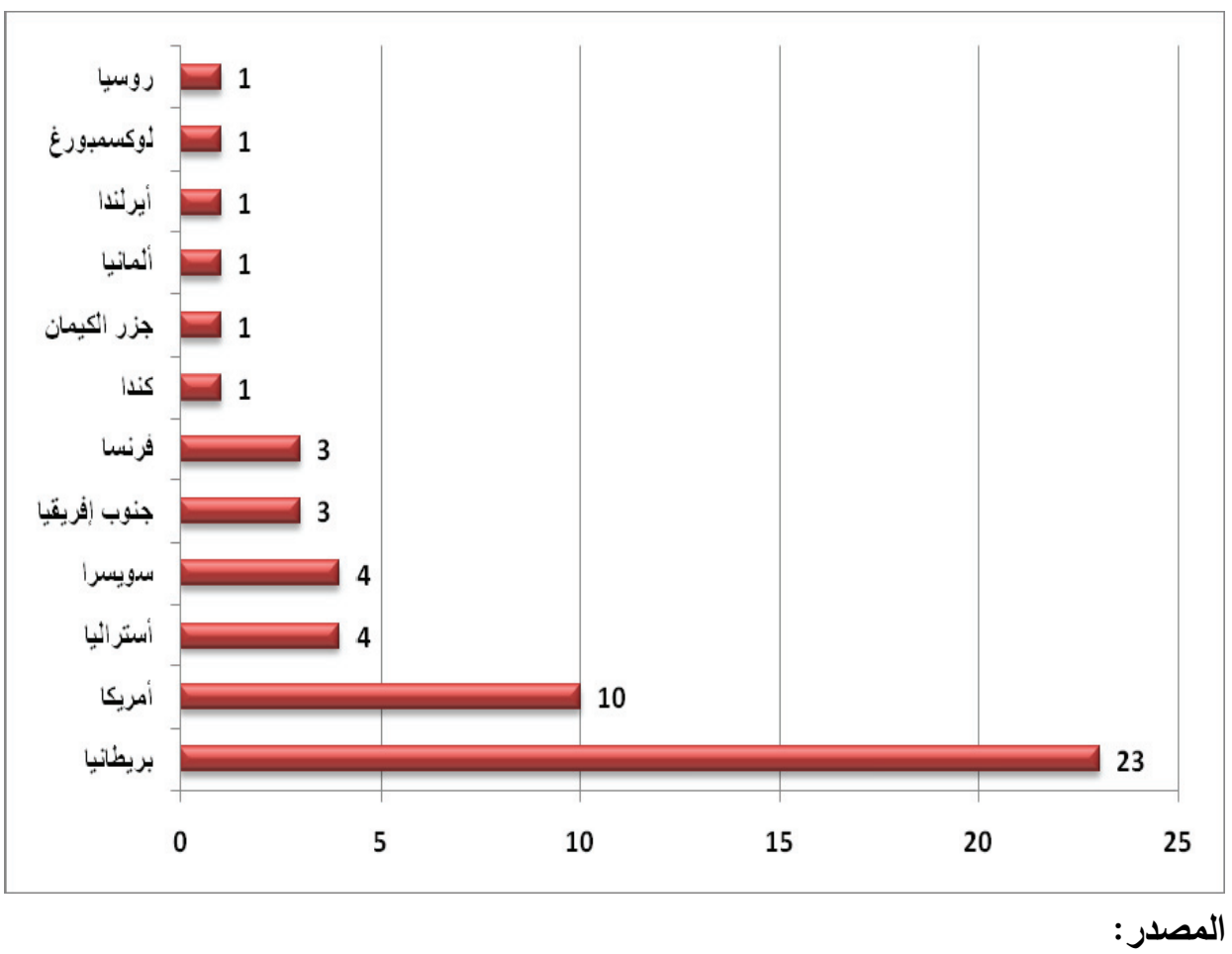

IFSL, Islamic Finance, 2010, p.3 Raza, M.F., "The European Opportunity", p. 44. City \& UK, Islamic Finance, May 2011, p.5.

شكل (1) عدد المؤسسات والنوافذ التمويلية الإسلامية في بعض الدول الغربية وغيرها.

ץ - حجم الأصول المتوافقة مع أحكام الشريعة الإسلامية، المتواجدة في هذا البلد آخذة في الزبـادة والنمـو • وبوضـح ذلك الثـكل رقم (r) خـلال السـنوات بين

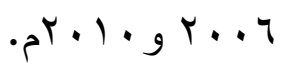




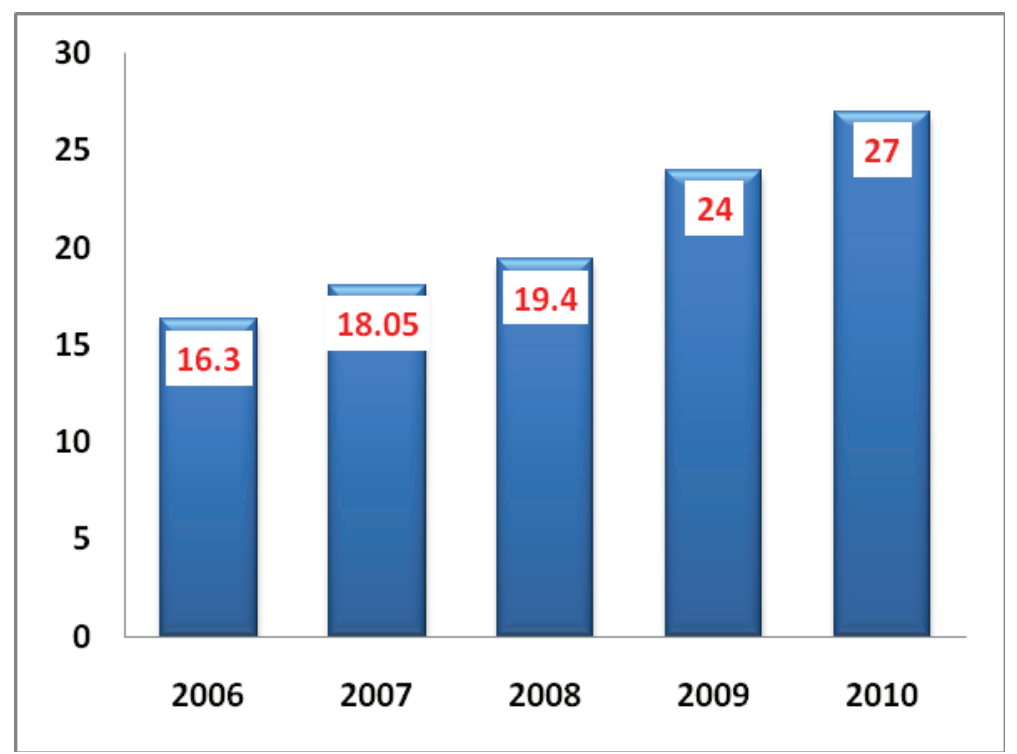

المصدر : . IFSL, Islamic Finance 2010, p.3 \& BMB Islamic, 2011, “GIFR 2011”, p. 35

شـكل (ץ) تطور حجـم الأصـول "المتوافقةة" مـع الشـريعة الإسـلامية فـي السـوق البريطانيـة بمليارات الدولارات.

يلاحظ من الثكل أعلاه أن حجم تلك الأصول نما بشكل منواصل وبمعدلات

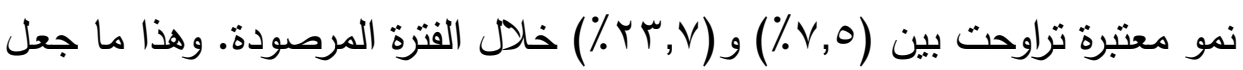
مرتبـة بربطانيـا تقفـز مـن المركـز العاثــر ضــمن تصــنيفات مجلــة ذي بـانكر (The Banker) لأكبر الدول المستقبة لهذا النوع من التمويل في جهازها المالي. ومن جهة أخرى فقد نمـا حجم الودائع التي اسـتقبها البنك الإسـلامي البربطـاني خـلال السـنوات الثناث الأولى من نشأته بشكل كبير ، يوضح ذلك الثكل (r). 


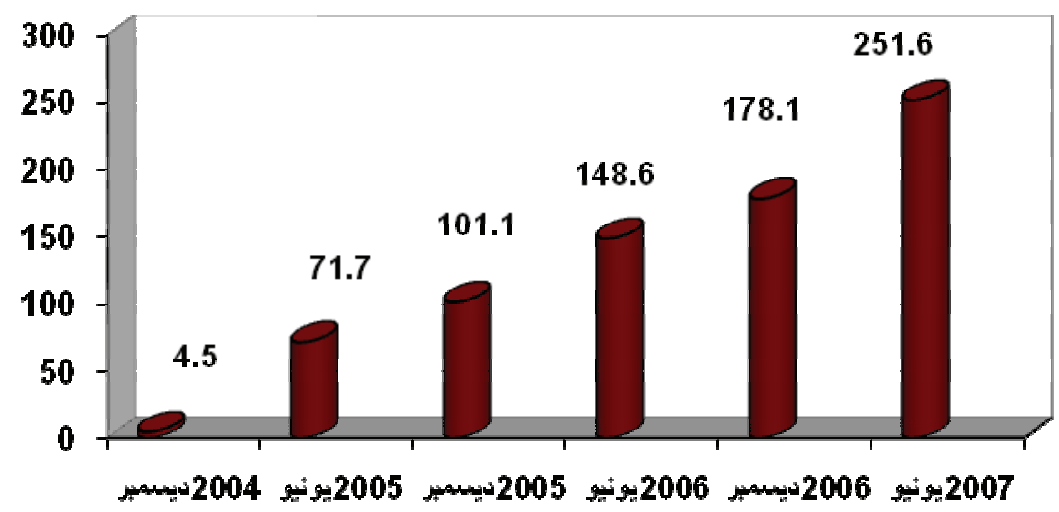

المصدر: UK Trade \& Investment Services, 2007, "The City- UK Excellence in Islamic Finance", p. 10.

شـكل (ب) تطور حجم ودائـع المصـرف الإسـلامي البريطـاني بملايسين الجنيهـات بـين عـامي $\cdot r \cdot v_{g} r \cdot \varepsilon$

والجدير بالذكر أن المؤسسات التمويلية الإسلامية الصرفة (full-fledged) ثقدم خدماتها جنبًا إلى جنب مع المؤسسات التقليدية التي تقدر بـ أمؤسسـة يأني على

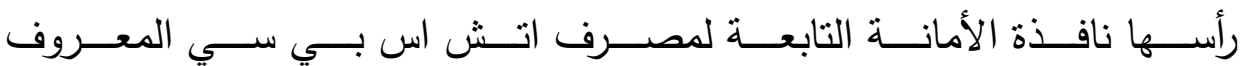
وهو الذي يمتلك (0^\%) (HSBC Amanah) مع الثربعة المشار إليها في الفقرة (r) أعلاه حسب إحصائيات 9 . . rم (ro). وهذا بعني أن حجم المؤسسات التموبلية الإسـلامية التي أنشئت خصيصًا لهذا الغرض لا يزال ضئيلاً، وأن الذي يدير معظم الأصسول نوافذ المؤسسات المالبة التقلبديـة. وهذه المؤسسـات مـع غيرهـا تقدم عـددًا مـن المنتجـات لتلبيـة احتياجـات السـوق

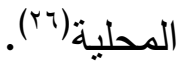

IFSL Resarch (2010) "Islamic Finance 2010", p. 3.

(YT) انظر الملحق (YT) حول معلومات تقصيلية عن بعض هذه المنتجات. 
r- عـدد المؤسســات التعليميــة والتلدريبيــة والخدميــة الأخــرى: حسـب المعطيات المتاحة تظهر بريطانيا أنها رائدة في هذا المجال، متقدمة في ذلك على المراكز العربية والإسلامية الرئيسة للتمويل الإسلامي كما يوضح الثكل (ع)، ومن جهة أخرى، فإنه نظرًا للجوء العديد من المؤسسات التموبلية الإسلامية إلى التحكيم

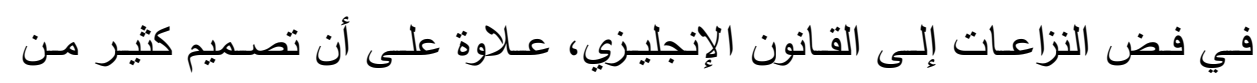

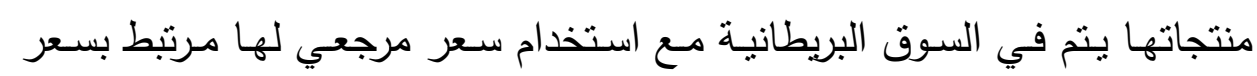

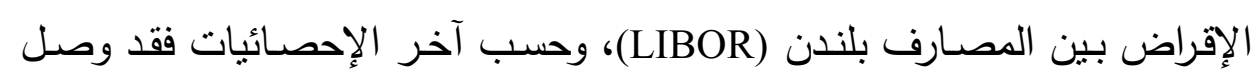
عدد الشركات التي تقدم استشارات قانونية إلى ثلاث وعشرين شركة(TV)

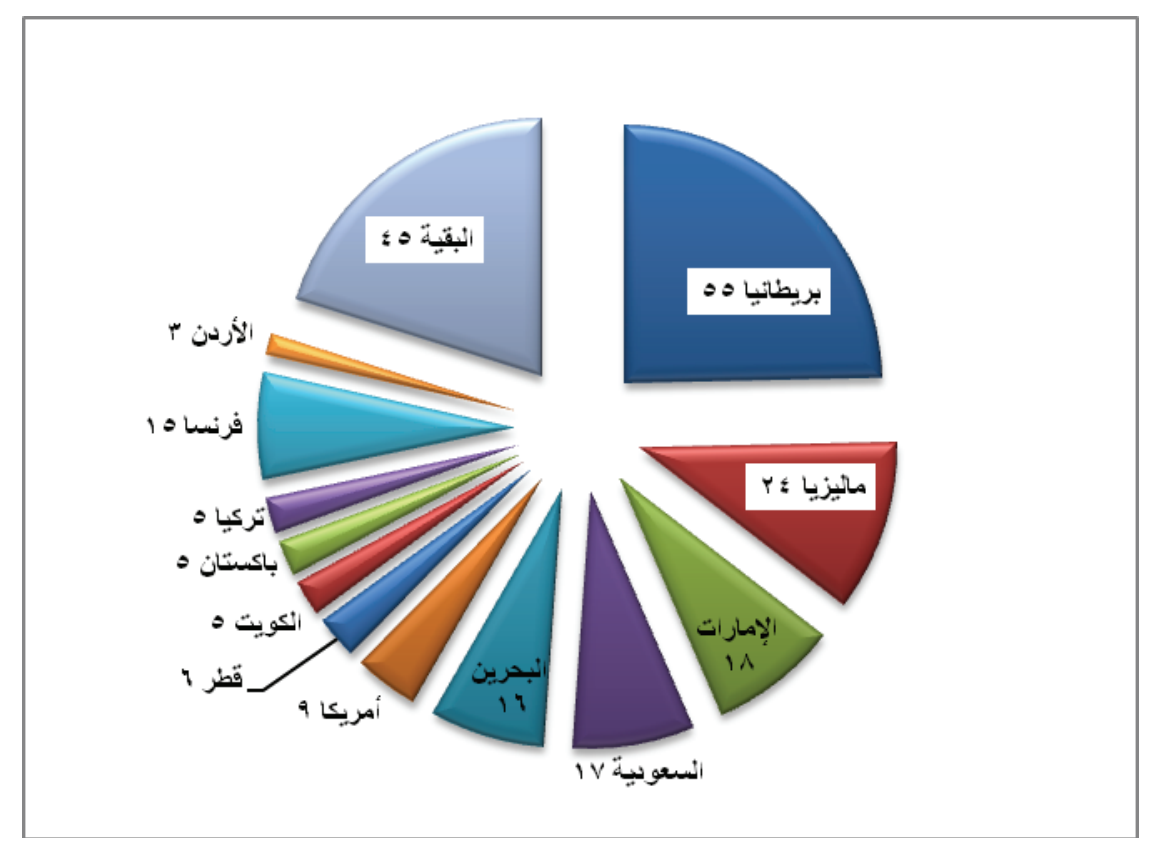

المصدر: IFSL, Islamic Finance 2009, p. 6

شكل (؛ ) عدد المؤسسات التعليمية والتدريبية التي تقلم برامج عن التمويل الإسلامي. 
وعلى المستوى الأكاديمي نجد أن عددًا من الجامعات البريطانية تمنح درجات علمية عالية (الماجستير والدكتوراه) في التمويل الإسـلامي، وبعضـها يقدم برامج

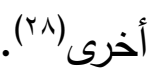

ع - تطور عدد الدراسـات العلميـة وغيرهـا التي تمت منذ السبعينيات وإلى عـام ^ ^ . rم من قبل غير المسلمين، حيث يلاحظ غلبة الموضوعات المتعلقة بقضـايا التمويل على غيرها من الجوانب الأخرى من فروع الاقتصـاد الإسـلامي.

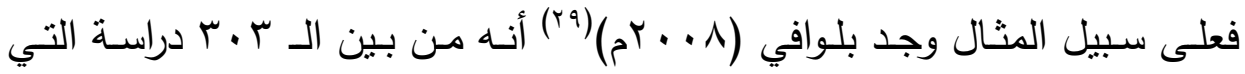

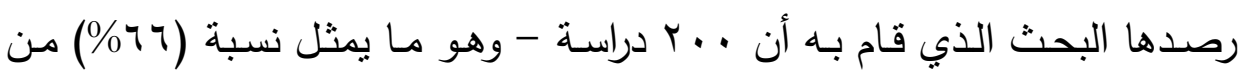
مجموع تلك الدراسـات- تتاولت جانب التموبـل والمصـرفية الإسـلامية مـن زوايـا مختلفة. كما ورصد الباحث أن وتيرة الدراسـات آخذة في الزيادة مع مرور الأيام. ويوضتح ذلك الثكل (0).

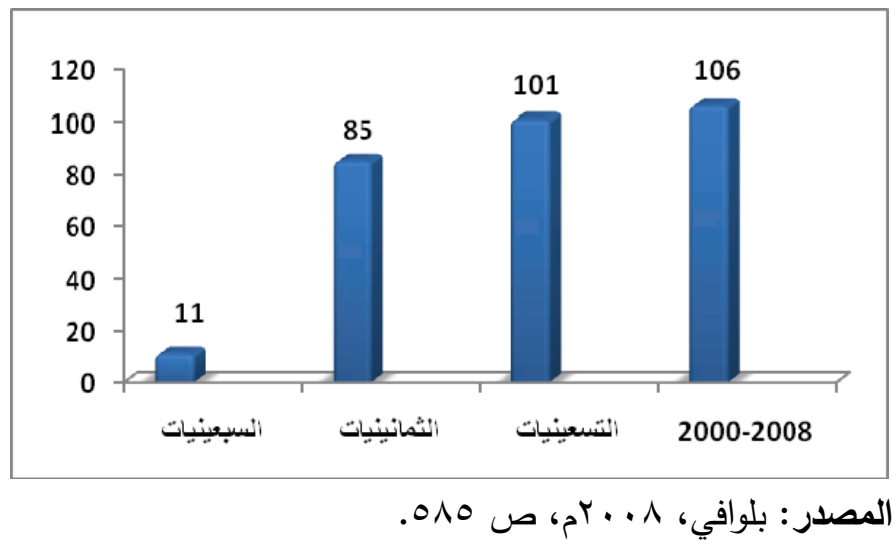

شكل (0) تطور عدد الدراسات عن الاقتصاد الإسلامي في بريطانيا منذ السبعينيات وإلى عام $\cdot{ }^{r} \cdot \lambda$

(Y^) انظر الملحق (Y) حول معلومـات تفصـيلية عن الجامعـات البريطانيـة وبعض المؤسسـات

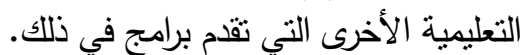

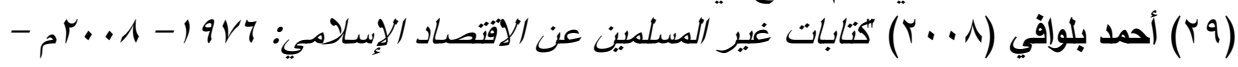

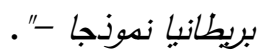


ومما يزبد الأمر وضوحًا أنه في نفس الدراسة المشنار إليها آنفا أنه تم رصد أربعين أطروحة علمية من قبل مسلمين وغيرهم نوقثت في الجامعات البريطانية

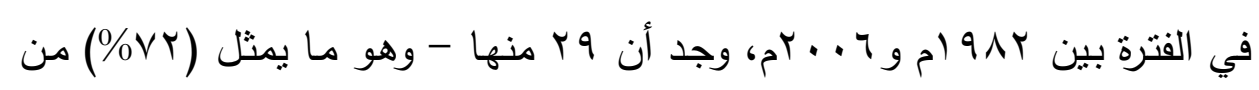
إجمالي تلك الأطروحات- تتاولت موضوعات تتعلق بالتمويل الإسـلامي (·r). ومن جهة أخرى، فإن الجامعات البريطانية والمعاهد المتخصصـة ومدارس تعليم اللغة تجنذب أعدادًا هائلـة من الدارسين المسلمين، وخاصـة من الدول الآسيوية ودول

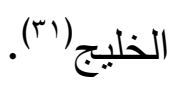

إن التطورات السابقة لم تكن لتحصل لولا توفر عدد من العوامل التي مهدت السبيل لتهيئة البيئة المناسبة لذلك. وهن العوامل التي يمكن ذكرها في هذا الصدد ما يلي (rr)

( ) الطريقة البراغماتية، وطبيعة النموذج الرأسمالي الذي اتبعته بريطانيا والذي يتيح مرونة معتبرة في التعامل مع رؤوس الأموال والاستثمارات الأجنبية

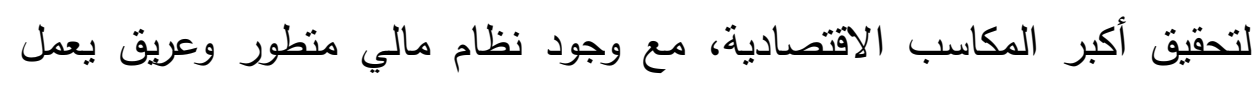
ضمن أطر قانونية وتتظيمية شهدت تطورات ومراجعات للتكيف مع التغيرات التي شهدتها الساحة العالمية بعد سقوط جدار برلين، والتي أصبح السجال التجاري والاقتصادي بين أقطاب النظام الرأسمالي من أهم معالمها.

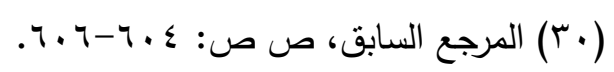

(T) على سبيل المثال يقدر عدد الطلبة السعوديين الذي يدرسون في بريطانيا بخمسة عثر ألف (10) على سبل ألف) طالب:

Ramkumer, K.S. (2010) "London remains centre for education, Finance: Lord Mayor".

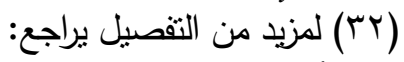

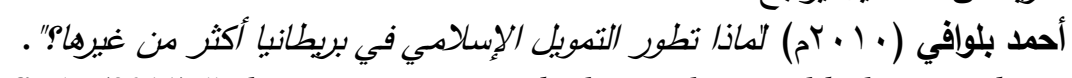
Belouafi, A. (2011) "Islamic Finance outside the Muslim World: the United Kingdom Experiment", pp. 7-9. 
r) دور الحكومة الفاعل في هذا المجال، وقد تمثل ذللك في الاهتمام بالموضوع والتعامل معه وفق مبادئ محددة؛ كالالنزام (commitment) من قبل الحكومة بترقية هذا النوع من التمويل في سوق المال البريطاني، والتعاون (Fairness) مع الأطراف المعنية، والانسجام مع القواعد المنبعة (collaboration) لتفادي المعاملة التفضيلية أو تلك التي تعوق أي نوع من التمويل، ويتم ذلك كله ضمن أهداف محددة تتمثل في: أولاً: تعزيز قدرة بريطانيا التتافسية كمركز مالي عالمي، وذللك بالعمل على أن يكون حي المال في لندن مركزًا عالميًا للتمويل الإسلامي. ثانيًا: العمل على عدم استبعاد أي مواطن بربطاني، بغض النظر عن بن معتقداته الدينية، من عدم الاستفادة من الخدمات التي يقدمها الجهاز المالي. r) وجود جالية مسلمة واعية ونشيطة وحريصة على العيش في كنف مبادئ الشربعة في مجالات الحياة المختلفة ومنها المعاملات المالية. وقد تجلى ذلك من خلال الأدوار التي تقوم بها بعض مؤسساتها في هذا المجال؛ ومن أمتلة ذلك فريق العمل الخاص (IFEG) الذي أنثأه المجلس الإسلامي البريطاني لمتابعة تطور التمويل الإسلامي بالتتسيق والتشاور (Muslim Council of Britain) مع الجهات الحكومية المسئولة عن هذا الملف، ومجلس التمويل الإسلامي الذي يتخذ من اسكتلندا مقرًا له لترقية التمويل الإسلامي، والتعريف به (IFCUK) داخل بربطانيا وخارجها. أما المؤسسة الإسلامية (The Islamic Foundation) التي أنشئت عام س 9 ام فتعنبر من المؤسسات العربقة والرائدة في مبدان الاقتصاد والتمويل الإسلامي، ليس على مستوى بريطانيا فحسب، بل على المستوى

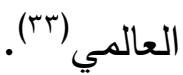

(Tr) وتقديرًا لهذه الجهود فقد حصلت المؤسسـة على جائزة البنك الإسـلامي للتنميـة السنوية لعام

$$
\text { ( }) \text { ( }
$$


ومن جهة أخرى لاشك أن بريطانيا تواجه منافسة من قبل دول أخرى أوربية

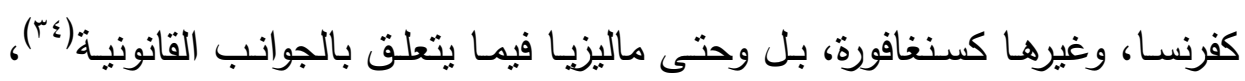

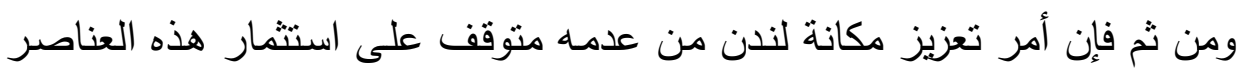

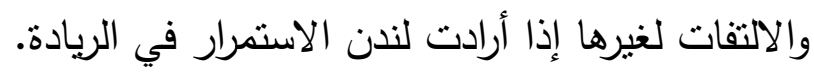

\section{ه- الفرص المتاحة للتمويل الإسلامي في بريطانيا}

من الفرص التي قد تتيحها السوق البريطانية للتمويل الإسلامي ما يلي (ro):

\section{ه- 1 توسيع قاعدة الزيائن وزيادة حصة السوق}

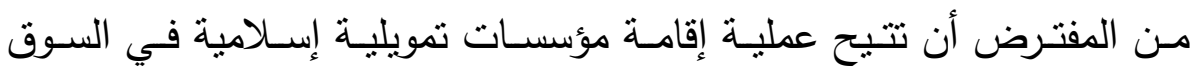

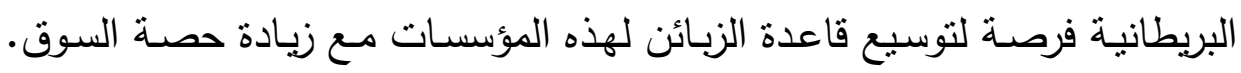

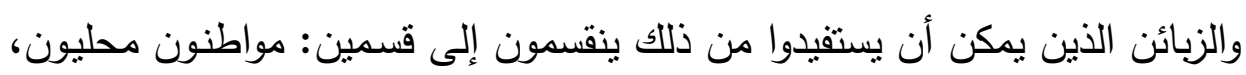

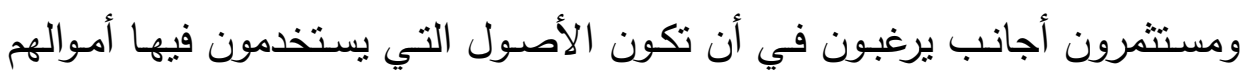

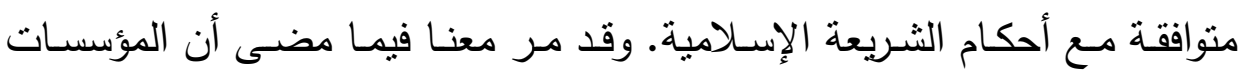

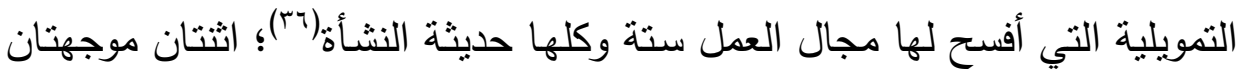

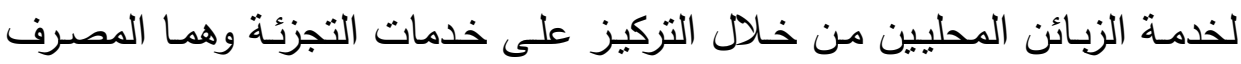

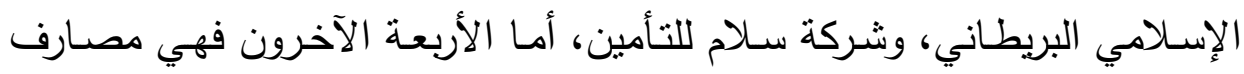

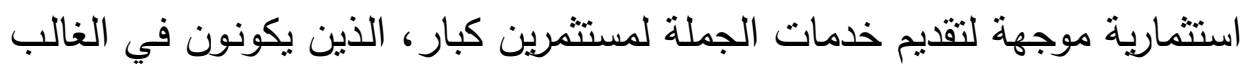
أجانب. علاوة على ذلك هناك بطبيعة الحال نوافذ المؤسسات التمويلية التقليدية والتي تعتبر نافذة مصرف اتش اس بي سي (HSBC Amanah) من أكبرها كما لفال مر معنا.

Belouafi A. and Belabes, A. (2011) "Islamic Finance and the Regulatory ( $\Gamma \varepsilon$ ) Challenge: The European Case", 16-18.

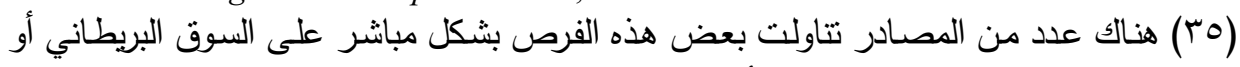

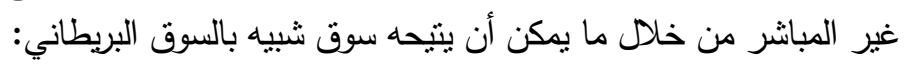

Arab Banker (2007) "Islamic Finance Opportunities and Prospects in Europe", pp. 51-52. Wilson, R. (2007) "Regulatory Challenges Facing the Islamic Finance Industry".

The Australian Trade Commission (Austrade) (2010) "Islamic Finance". ( (Tr) لم يمض على أقدمها نثأة أكثر من ست سنوات، وهو الكصرف الإسلامي البريطاني. 
وإذا قارنـا مستوى الحجم الذي وصل إليه التمويل الإسـلامي بجميع أثكاله،

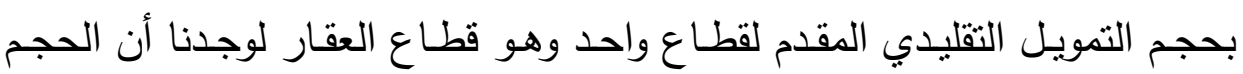

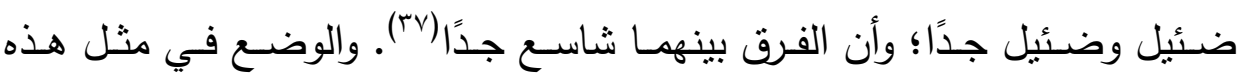
المرحلة التي تمثل بداية الانطلاقة بالنسبة للتمويل للإسلامي، والنضـج والبلوغ فيما يخص التمويل التقليدي لما لفارق العمر والرسوخ بين الاثتين من هوة كبيرة ليس بمستغرب، ييقى السؤال بعد ذلك هل نمو التمويل الإسلامي يسير بوتيرة نشير إلى

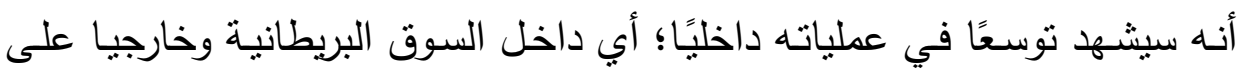

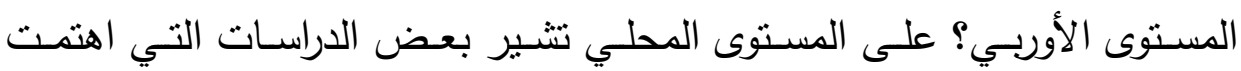
بتحليل جانب الطلب على المنتجات المالية الإسلامية المقدمة لتمويل المساكن إلى أن الإقبال عليها لا يزال ضعيفًا (^^)، وذلك نظرًا لقلة وعي أفراد الجاليـة المسلمة

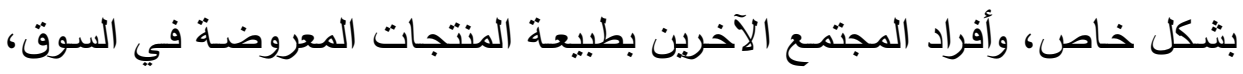

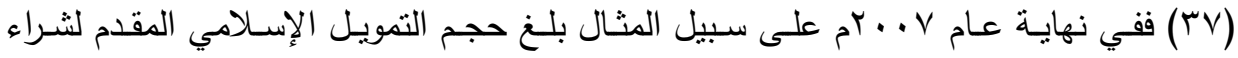

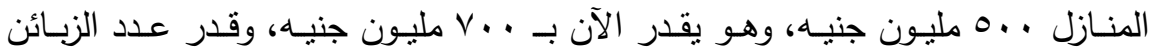

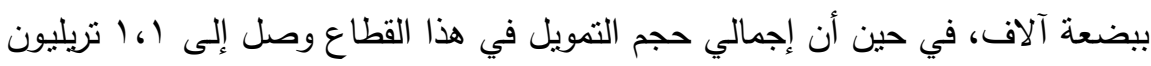

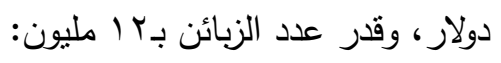

The Financial Services Authority (2007)"Speech by Clive Briault, Managing director, Retail Markets, FSA", \& Wilson, R.J.A. (2009) "Islamic Finance in Europe".

UK Trade \& Investment Services (2010) "Supportive Legislation Boosts UK's World-Leading Islamic Finance Industry".

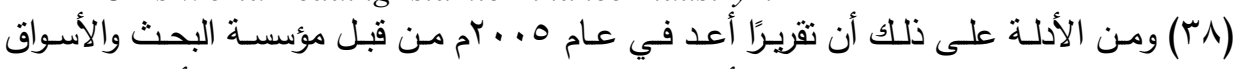

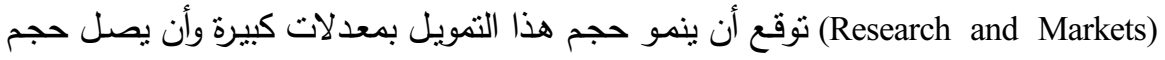

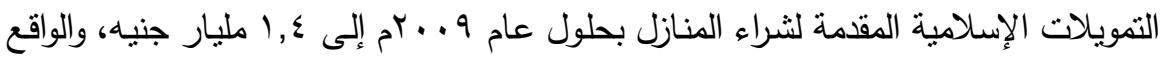

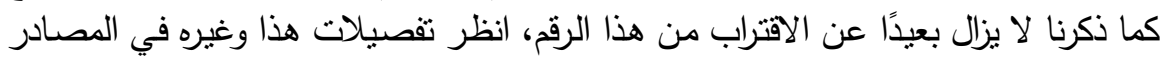

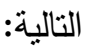

"UK Islamic Mortgages Worth Billions", www.islamicmortgages.co.uk.

Januja, N. (2010) " Is the Islamic Mortgage market dying a slow death?".

Mathews, R., Tlemsani, I. and Siddiqui, A. (2003) "Recent Developments in the Market for Islamic Mortgages: Theory and Practice".

Dar, H. A. (2002) "Islamic Housing Financing in the United Kingdom: Problems, Challenges and Prospects".

Wilson, R. (2009a) "Islamic Finance in Europe". 
ولمحدودية دخول أفراد الجالية كذلك(")، وهذا ما يفرض على الصناعة والمهتمين

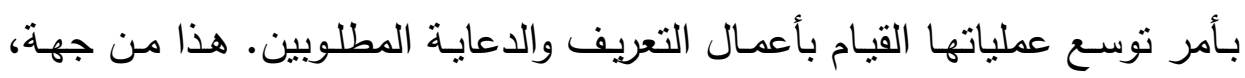
ومن جهة أخرى هناك عامل "التقة" وهو الأهم، ويتمنل في مدى قناعة الأفراد بأن

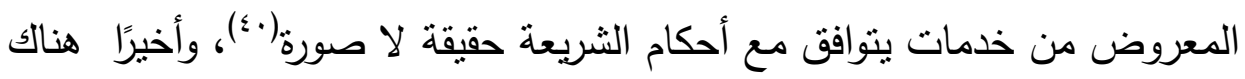

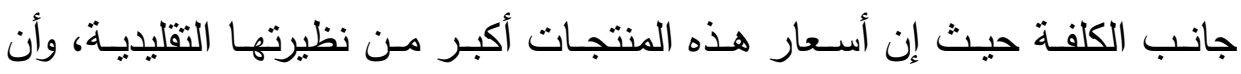
المنتجات التي تقدم من خـلال نوافذ المؤسسـات التقليدية أقل كلفة من تلك التي تقدمها المؤسسات الإسلامبة الصرفة.

وفي ما يتعلق بالجانب الخارجي فهنالك إمكانية التوسع على المستوى الأوروبي

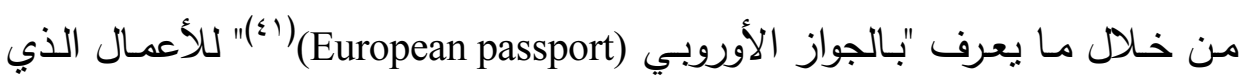
يؤهل الأفراد والمؤسسـات التجاربـة أو الخدميـة المسجلة في إحدى الدول الأوروبيـة المنضمة لمنطقة الاقتصساد الأوروبية (European Economic Area) بمزاولة العمل دون الحاجـة إلى إصـدار ترخيص خـاص ومـا يترتب عليـه مـن إجـراءات إداريـة وقانونية قد تواجه بـالرفض، وهنا ستتسع قاعدة الزبائن لتشمل المسلمين المقيمين

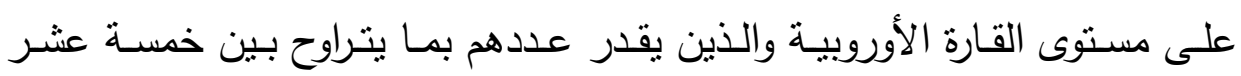

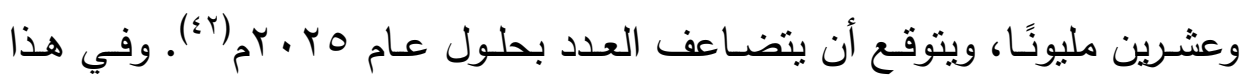
الصدد قام مصرف جيت هاوس (Gate House) بتقديم طلب لساحة باريس أورو

Wilson, R. (2009a) "Islamic Finance in Europe".

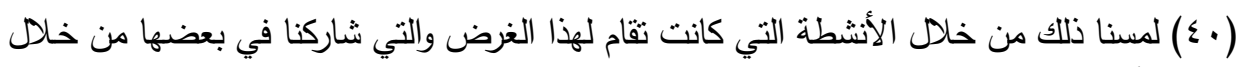

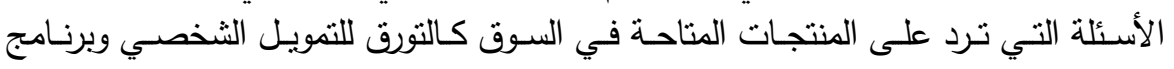

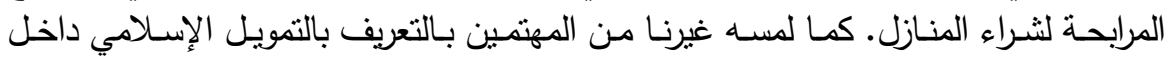

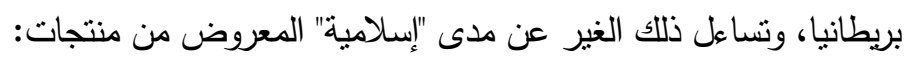

Shaikh, O. (2010) "Development of Islamic Finance in the UK \& Europe", p. 9.

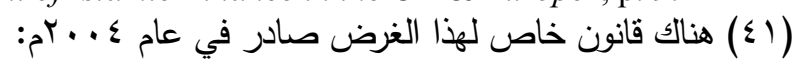

"Subsidiary legislation 371.11: European passports rights for Credit institutions", docs.justice.gov.mt.

Open Society Institute (2009) "Muslims in Europe: A Report on 11 EU Cities", p. 22. ( $\leqslant$ Y) 


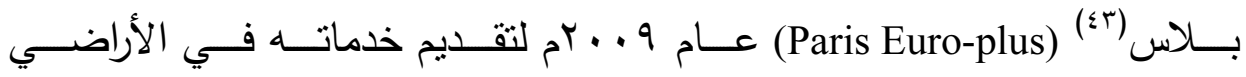

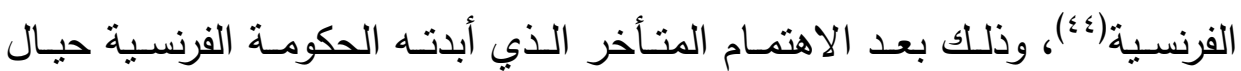

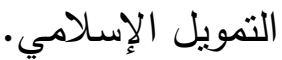

مدـا سبق ذكره يتضـح أنـه في الوقت الذي يشـير فيـه الواقع النظـري إلى إمكانية استفادة التمويل الإسلامي من اقتصاديات النطاق (Economies of scope) باقتحام أسواق جديدة، فإن الواقع العملي على مستوى السوق البربطاني يشير إلى

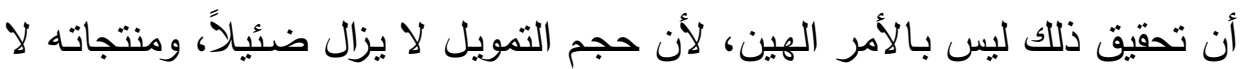
تزال مرتفعة التكاليف، علاوة على ما تلقى المؤسسات التمويلية الإسـلامية الصرفة مـن منافسـة مـن قبـل النوافــ الإسـلامية للمؤسسـات التقليديـة، بالإضـافة إلى عامـل الثقة الذي يمثل عنصـرًا هامًا في المعـاملات المبنيـة على أساس الدِّين.

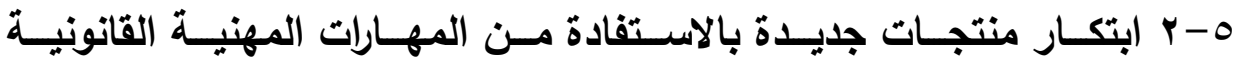 والمحاسبية.}

نظرًا لما للندن وسوقها المالي من عراقة وتطور ، ولما لها من صلات تجارية

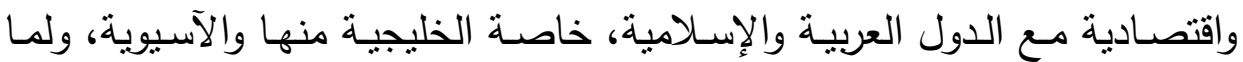
لثركاتها الاستشارية والقانونية من مهارات فنية وخبرة على المستوى العالمي(0؛)، ولمـا لقانونها العـام من مكانـة مرجعيـة في تصـيم العديد من المنتجات والعقود،

( ) هكذا نتطق بالفرنسية أما بالإنجليزية فنتطق يورو.

Parker, M. (2009) "UK Islamic Finance gets foothold in France".

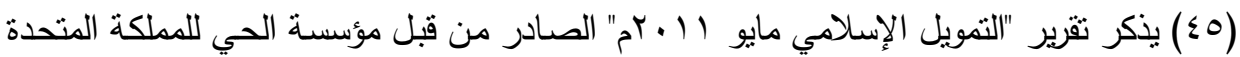

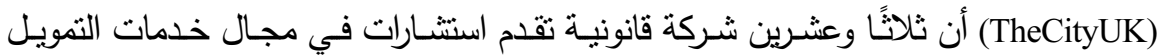

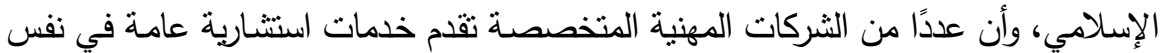

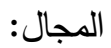

TheCityUK (2011) "Islamic Finance May 2011", p.10. 
وكذا فض النزاعات حيث يعتبر القانون الإنجليزي المرجع الرئيس في ذلك(َ؛)، فإن

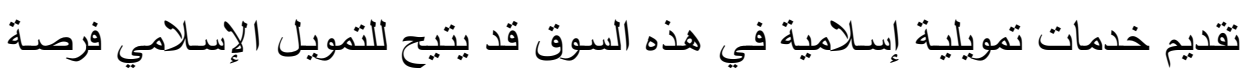

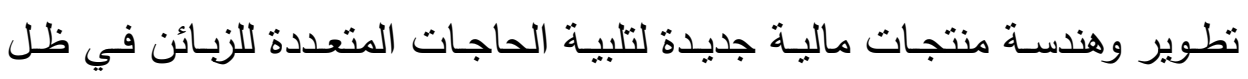
وضع سوقي شديد التتافس.

وهنـا يمكن الإثـارة إلى بعض المجـالات التي تحتاج إلى تطوير منتجات لتلبية طلبات الزبائن عليها؛ منتجات ومحافظ متخصصـة لجذب رؤوس الأموال

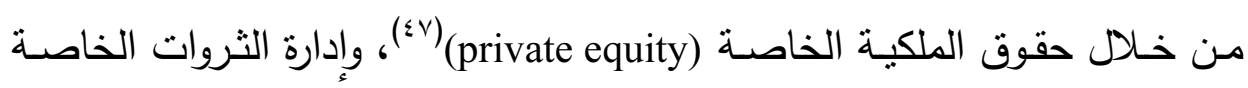

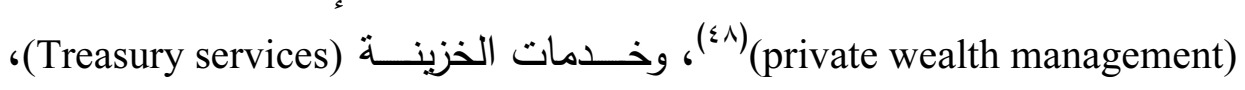

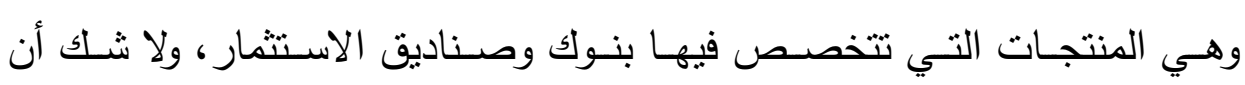

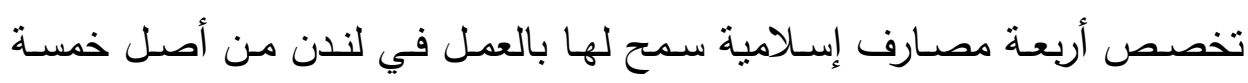
يهذف إلى الاستفادة من هذا.

ومع إقرار أهمية ما سبق، فإن الأمر لا يخلو من مخاطر ترافق أمر تتفيذه

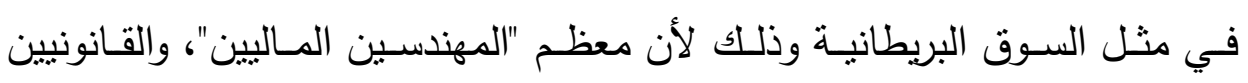
والمحامين اعتادوا على مسلكيات البيئة التقليديـة التي يغلب عليها أدوات الدَّين القائم على الفائدة (الربا)، ومن أهم تلك المخاطر السـامة الثرعية للمنتج، ودرجة التعقبـد، وانعـدام الثـفافية، وهـي أهـور تشـاهم في التأثثر على السـمعة وتضـر بالصناعة في حاضرها ومستقبلها.

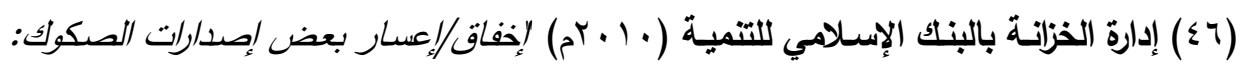

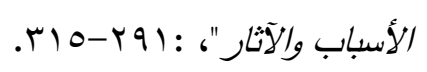

(§V) ويقصد بهذا الاستثمار في شركات غير مدرجة في أسواق المال، وعادة ما يتطلب المشاركة

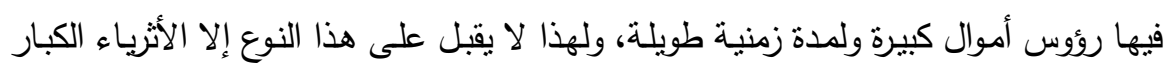
والثركات لأن مخاطر خسارة رأس المال عالية. IFSL Research (2010) "Islamic Finance 2010", p. 3. 
ه-r تطوير سوق ثانوية للأوراق المالية الإسلامية(؟) وإن كان الوضـع الحالي يشير إلى ضـآلة ومحدوديـة هذا الأمـر خاصـة بعد عزوف بريطانيا عن إصدار صكوك سيادية، وتردد الدول الأخرى في ذلك لكن إذا تطـور سـوق الصـكوك في السـوات القادمـة بالثـكل الـذي تتحدثث عنـه بعض التقارير ، فإن إمكانية تطوير ذلك واردة. ه- ـ تعزيـز مكانـة وأهميـة الأخـلاق والقيم فـي المعـاملات الماليـة والصـفقات التجاربة

لقد بـات الحديث عن الأخـلاق بـالمفهوم الذي أوضــناه سـابقًا والقيم بلقى اهتماءًا كبيرًا في الأدبيات الماليـة والتجاريـة، وازداد أمر الاهتمـام بشكل أكبر في ضوء الأزمـة المالية العالمية، بعد أن اتضـح أن غياب هذه الجوانب في منظومـة النة المال والأعمال تزيد من مخاطر عدم الاستقرار ، ليس فقط على مستوى المتعاملين

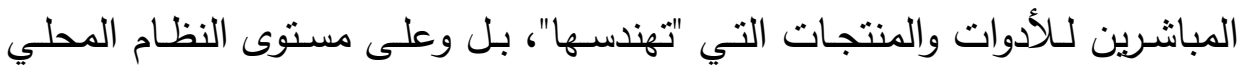
والعالمي أيضًا. وارتباط التمويل الإسـامي بالدِّين وارتكاز مبادئه وأسسه على ذلك يزبـد من هذا الأمـر ، بـل يفتح آفاقًا من شـأنها أن تعزز ذلك، خاصــة أن معظم مبادئ التموبـل الإسـلامي كتحريم الربـا والقمـار ، أمـر مشترك بينه وبين الديانات السـماوية الأخـرى، بـل ويتقـاطع في ذلك مـع الـديانات الأخـرى، كمـا أن أدواتهـ ومنتجاته ليست مقتصرة على المسلمين، وقد أشـارت التقارير الرسمية البريطانية لهذه الحقيقة للتأكيد على أن التمويـل الإسـلامي يوسـع قاعدة خيـارات المنتجـات والخدمات المالية لزبائن النظام بشكل عام وليس للمسلمين فحسب(.0).

Wilson, R. (2007) "Regulatory Challenges Facing the Islamic Finance Industry", p.4. ( ( १)

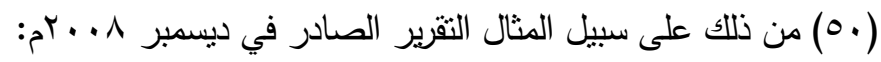
HM Treasury (2008) "Development of Islamic Finance in the UK: Government's Perspective", p. 7. 
فقي ظل الأزمـة كتب اقتصـاديان بريطانيان (10) عن أهميـة مبـادئ التمويل الإسـامي في تحقيق العدالة في المعاملات المالية، وأهمية الاستفادة من الالتزام بمتطلبات مبدأ بيسع الإنسان مـا لا يملك، ومن أمثلته الواضـحة التي برزت في الأزمـة الأخيرة مـا بـات ينعت بالمشـتقات العاريـة (Naked Derivatives) الحد الذي ذكر فيه بوبتر (Buiter, 2009a) ضـرورة فتح نقاش جاد للتوصل إلى الى حرمـة هـا النوع مـن المنتجـات. كمـا أثـارت تلك المقالات إلى أهميـة مبـادئ التموبل الإسـامي في إعادة الفاعلية للسياسـة النقديـة، وإحداث نوع من الاستقرار في النظـام المـالي في ظل فشـل سياسـات التوسـع النقدي التي انتهجب لاحتواء الأزمة والتغلب على آنارها. منل هذه الكتابات من أكاديميين وتطبيقيين (ro) وغيرهم مـع تواجد تموبـل إسـلامي في بعض البيئات من شـأنه أن يعزز موقف المهتمين بالتمويـل الخُلقي، والمنـادين بضـرورة إعادة القيم لمجـال المـال والأعمـال، وتقديم التمويل الإسلامي المثال في التطبيقات سيكون له أبلغ الأثر .

\section{V- - الاستثمار في المشاريع المتوسطة والصغيرة والبنى التحتية والطاقة المتجددة}

إن انتقال التموبل الإسـلامي لبيئات جديدة من شأنه أن بفتح فرصـة التفكير في المشـاركة في تمويل مشروعات تلقى اهتمامًا كبيرًا في وسط هذه البيئات لما

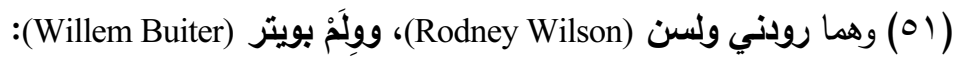
Wilson, R. (2009b) "Why Islamic Banking Is successful?".

Buiter, W. (2009a) "Should you be able to sell what you do not own?".

Buiter, W. (2009b) "Islamic finance principles to restore policy effectiveness".

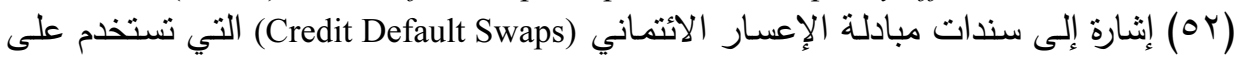

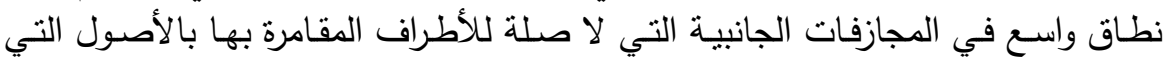

$$
\text { تنتند إليها هذه الأدوات. }
$$

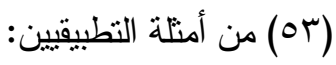

Thomas, R. (2010) "Islamic finance may "return to roots"'".

Birch, T. (2010) "Islamic Finance Offshore: Present and Past".

Gavin, J. (2010) "Islamic Insurers Eye global Market". 
يتوقع منها من آثار اقتصادية على البلد، ولما قد تدره من عائد أفضل من ذالك

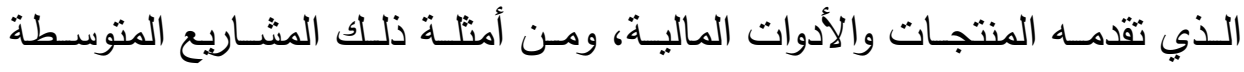
والصـيرة، ومشـاريع البنى التحتية، والطاقة المتجددة. ومن الممكن في مثل هذه الحالات أن يكون هناك تعاون بين التمويل الإسلامي مع نظيره التقليدي إذا كانت الاستثمارات واعدة والأمر مجد للطرفين بطبيعة الحال، وهذا ما قد يعزز حقيقة أن التمويل الإسلامي ليس "انعزاليًا"، ولا هو مختص بفئة لوحدها، بل إنه مناح للجميع بغض النظر عن العرق والدِّين.

\section{צ- التحديات والعقبات التي تواجه تطور التمويل الإسلامي في بريطانيا}

يلاحظ من خلال الدراسات التي تم استعراضها أن هذا الأمر تولى له عناية أكثر من غيره(ه)، وذلك راجـع في تقديرينا إلى الاختلاف الجوهري مـن حيث المبادئ بين الفلسفة التي يقوم عليها التمويل الإسلامي وتلك التي يقوم عليها نظيره

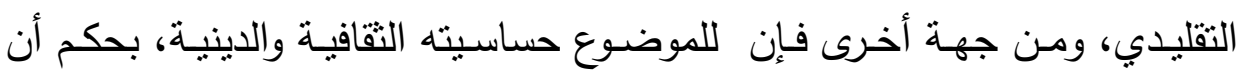
السماح للتموبـل الإسـالامي بمزاولـة العمل في البيئات الغربيـة ولدت معـه نقاشـات حول انعكاسـات ذلك على الواقع القانوني والثقافي لتلك الدول؛ نقاشـات نركزت حول سؤالين مهمين وهما: هل يعني ذلك إدخال قوانين إسـالاية ضمن القوانين

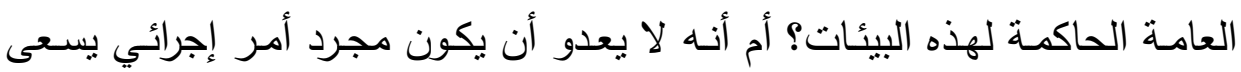
لتوفير الأرضية المناسبة لإدراج هذا النوع من التموبل ضمن المنظومة التشربعية والإشرافية القائمة؟(00)

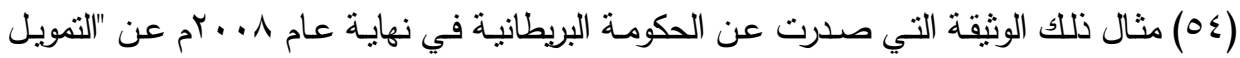

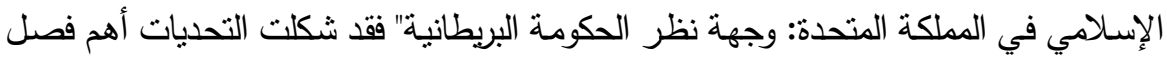
فيها، حيث احتل سا صفحة من أصل TV TV صفحة التي حوت المباحث الرئيسة للوثيقة.

Wilson, R. (2007) "Islamic Finance in Europe", p.1. and Wilson, R. (2007) (00) "Islamic banking - Opportunity or Threat?". 
وفيمـا يلي استعراض لأهم التحديات والتي استخدمنا في بعضـها المنهجيـة

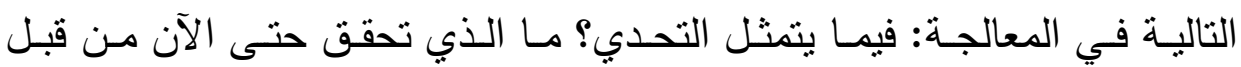

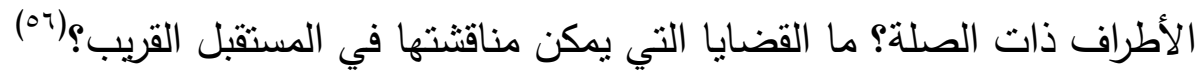
7 - أحدان الهوية ومخاطر السمعة (Identity loss \& Reputation risk)

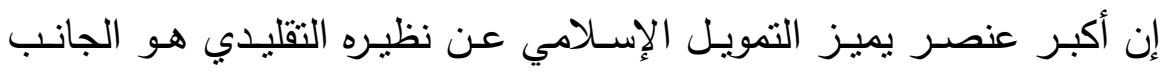

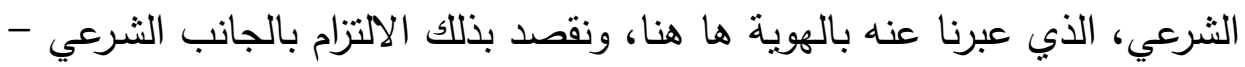

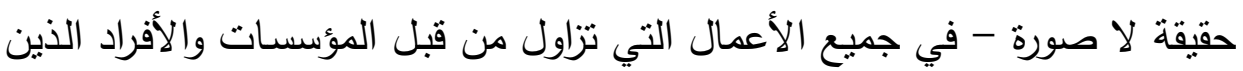

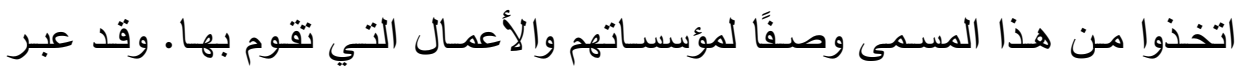

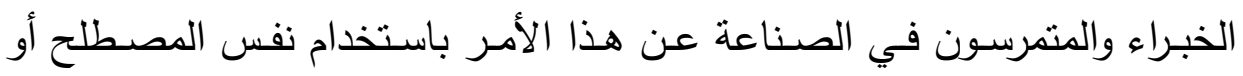

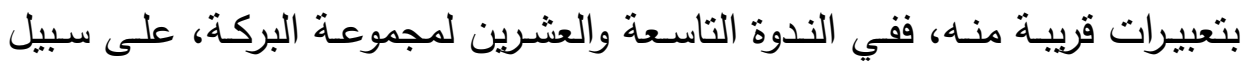

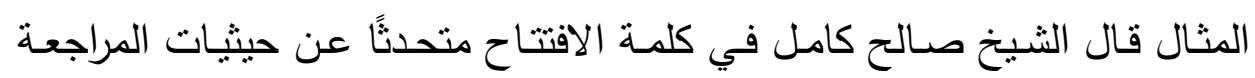

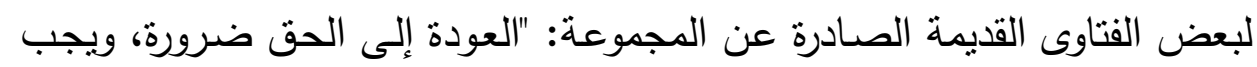

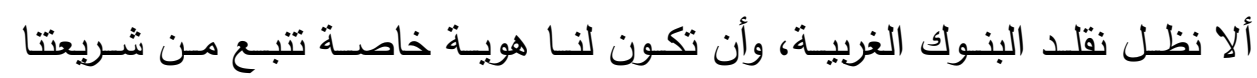

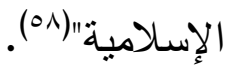

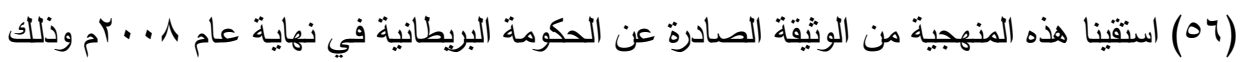

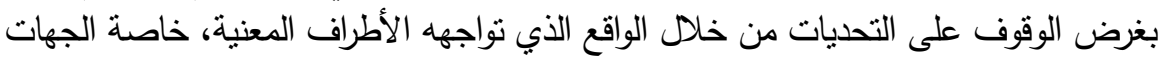

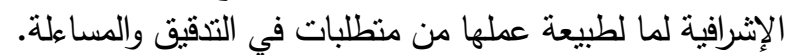

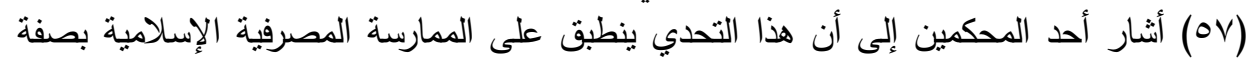

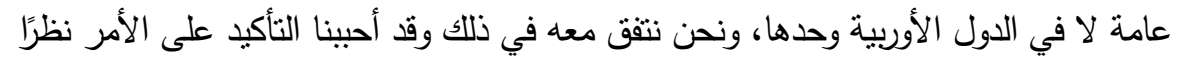

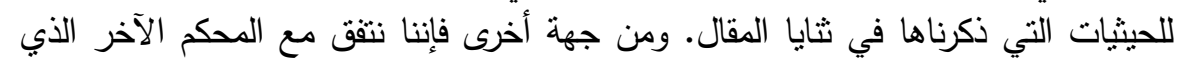

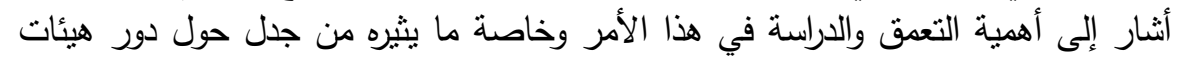

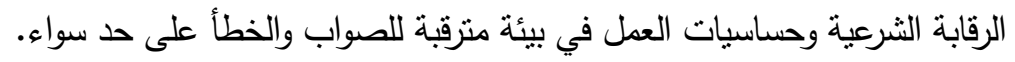

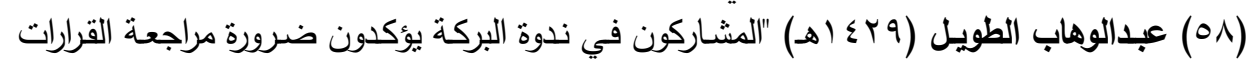

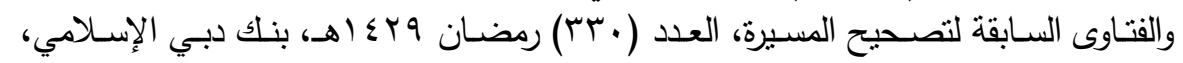

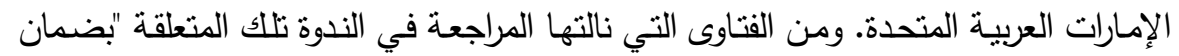

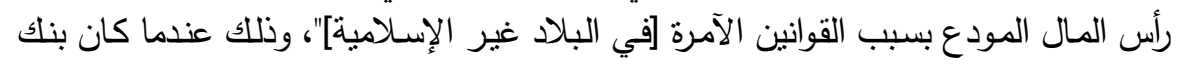

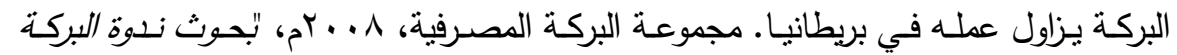

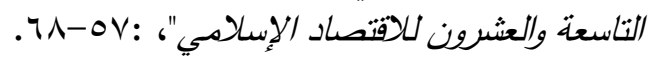


فهل وجود هذا النوع من التمويل في بيئة تقلبدية عريقة كالسوق البريطانية

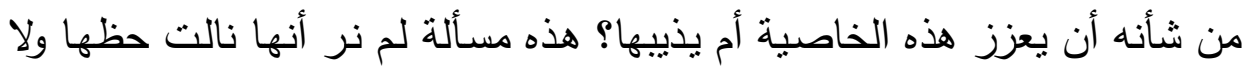

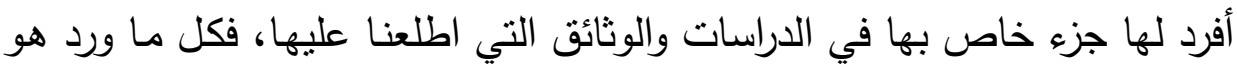

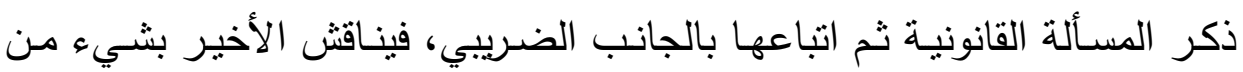

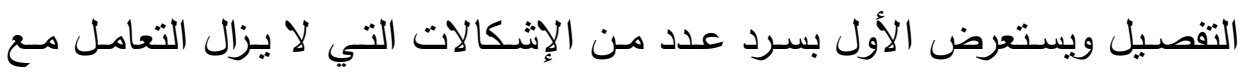

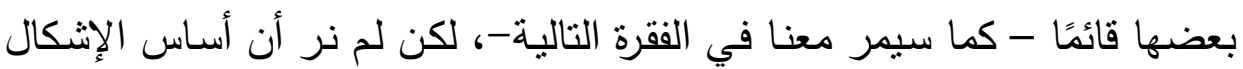

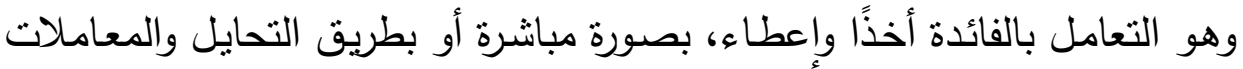

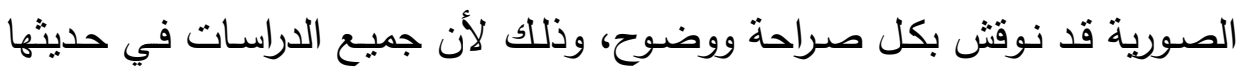

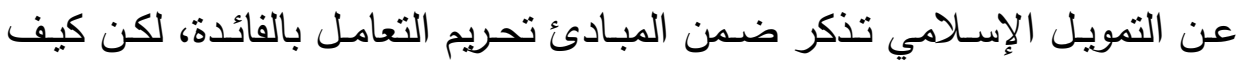

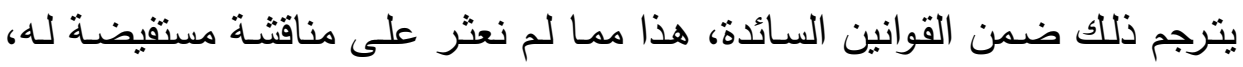
ناهيك عن الحصول على جواب واف في الدراسات التي تمكنا من الاطلاع عليها.

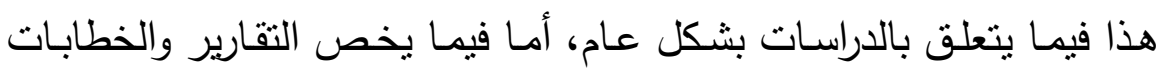

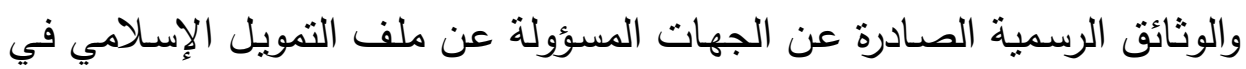

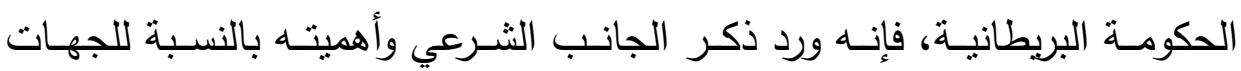

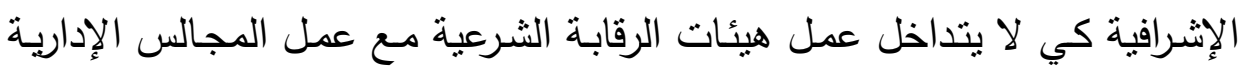

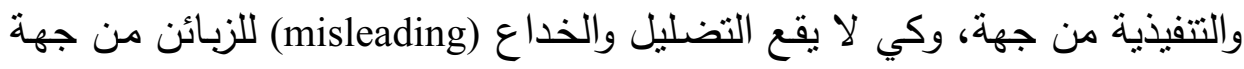

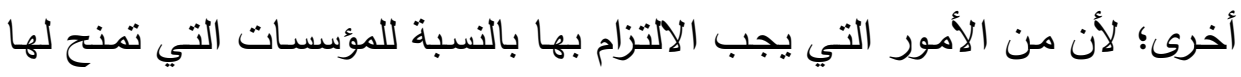

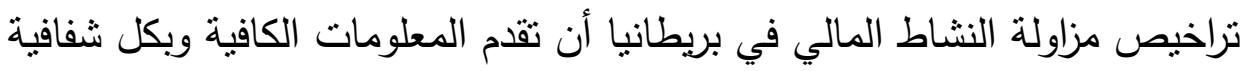

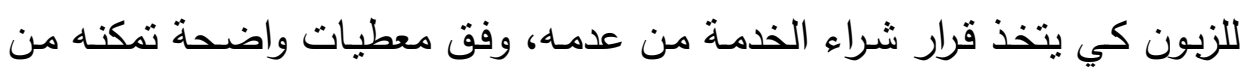

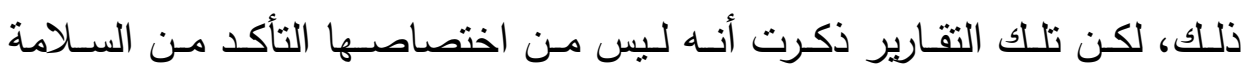

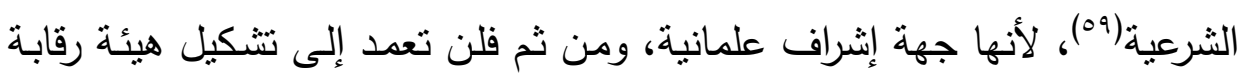

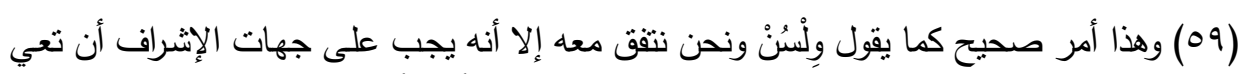

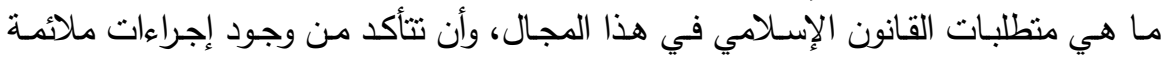

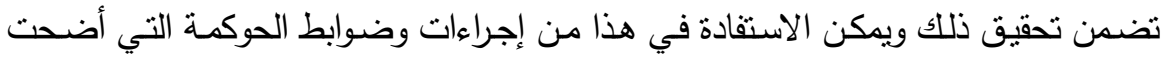

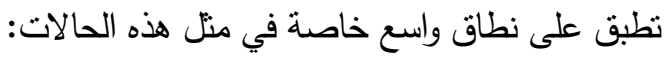

Wilson, R.J.A. (2003) "Regulatory challenges posed by Islamic capital market products and services", p.1. 
شرعية مركزية ضمن جهاز الإشراف على القطاع المالي، وألقت بهذه المهمة على

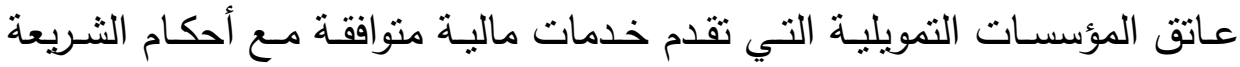

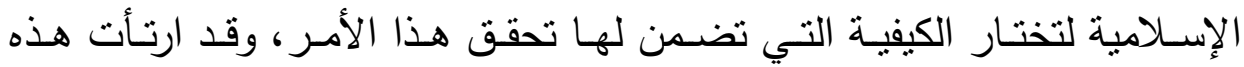

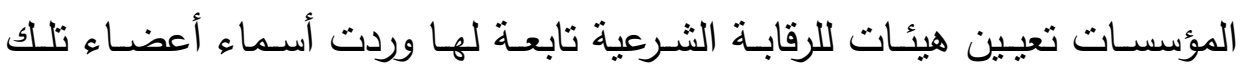

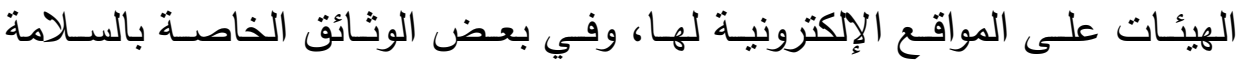
الثرعية للمنتجات.

ومن ثم يمكن القول إن تحقيق الهوية أو الانضباط الثرعي ارتبط حتى الآن بهيئات الرقابة الثرعية التي تتبع لهذه المؤسسات، وقد كثر الأخذ والرد حول الدور

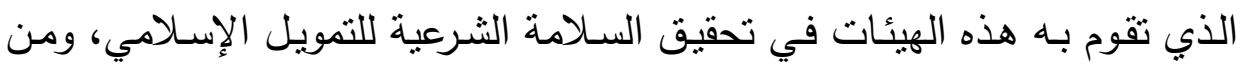

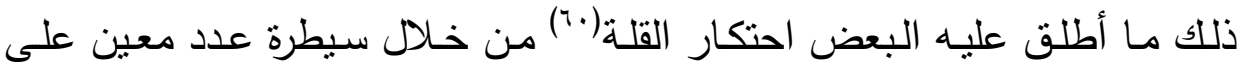

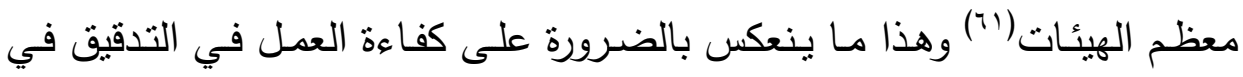

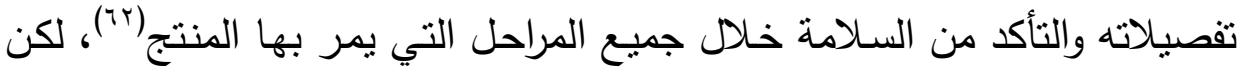

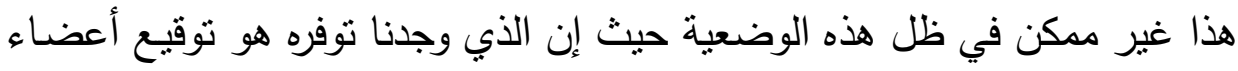

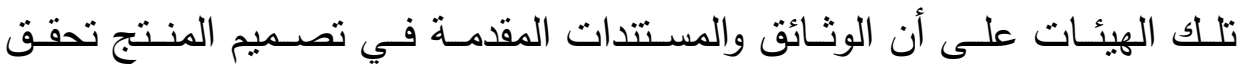
الضوابط الشرعية، أما بعد ذلك فلم نعثر على ما يؤكد على المتابعة من خـلال

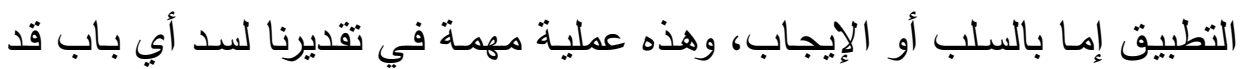

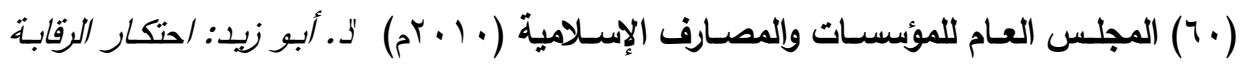

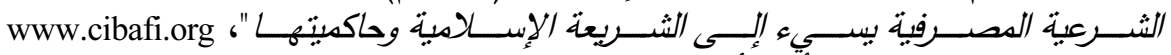

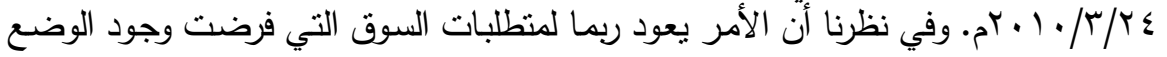

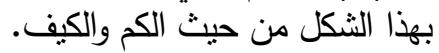

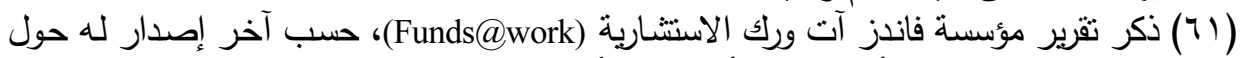

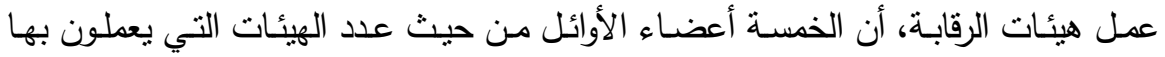

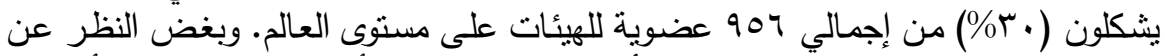

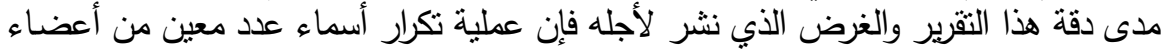

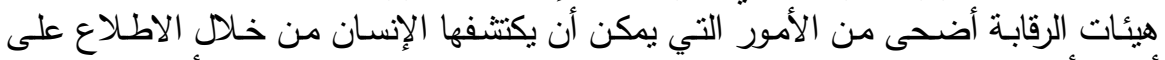

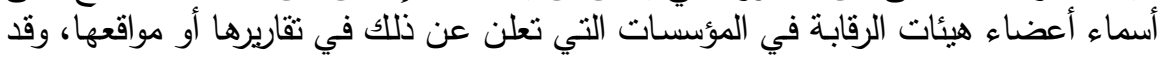
وقفنا على ذلك في التجربة البريطانية: Ünal, M. (2010) "Shariah Scholars - A Network Analytical Perspective". Ainley, M., et al, (2007) "Islamic Finance in the UK: Regulation and Challenges", p. 17. (7r) 
يستخل في سبيل إثارة الثكوك حول عمل هذه الهيئات. والأمر الآخر الذي بدأ الحديث عنه بتعلق بما بمكن وصفه بمسألة تضارب المصالح وتحقيق الاستقلالية لهذه الهيئات التي تتلقى مكافآتها من الجهات التي تقوم بمراجعة عمهاتهآج). ولهذا فقد أثنارت السلطات البربطانية إلى بعض هذه المسائل، حيث إن المطلوب منها بهات

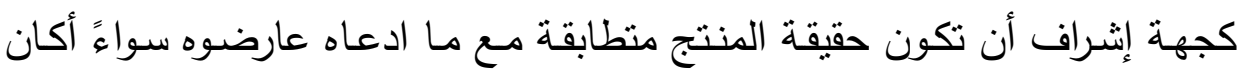

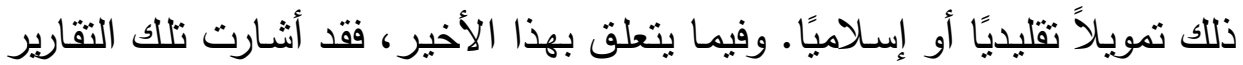

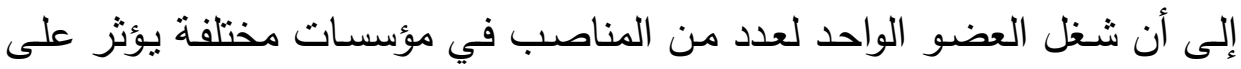

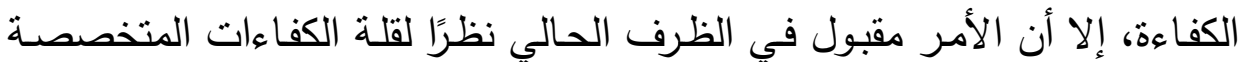
في هذا المجال(عَ7)، كما تذكر تلأك التقارير .

إن مـن الانعكاسـات التـي قد تتـتج عـن هـا التحدي فيمـا يتعلـق بالبيئات التقليدية عمومًا والغربية منها على وجه الخصوص هو أن تسود التطبيقات غير

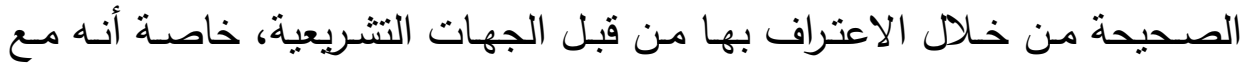
التطور الحاصل في الهندسة المالية يمكن هيكلة أيـة معاملة للتحايل على الربا(70) من خلال التركيز على الجوانب الثكلية التي قد تحقق المبنى ولا تفي بالمقصد

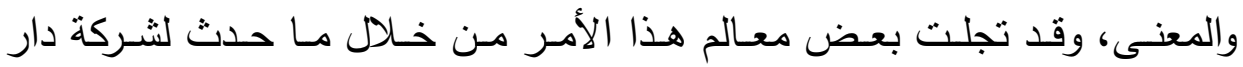

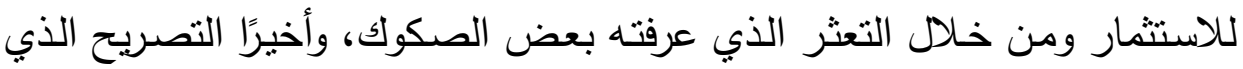
ذكره أحد النافذين في هذه الصناعة(ب7) من أن معظم المنتجات المتداولة تحت

HM Treasury (2008) "The Development of Islamic Finance in the UK: the (TT) Government's Perspective", p. 26.

Ibid, p. 25. ( $7 \varepsilon)$

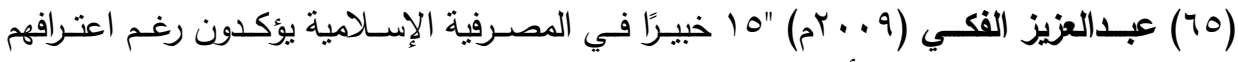

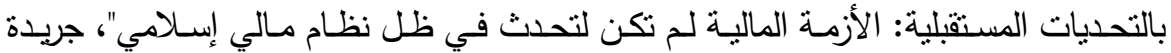

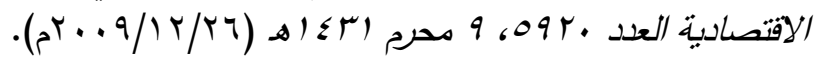

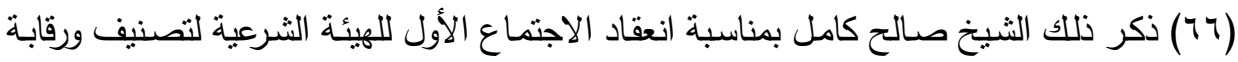

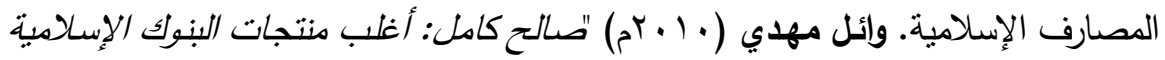

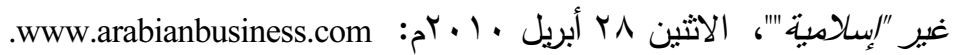


مسمى الإسلامية ليست كذللك، مما تطلب العمل على إيجاد هيئة شرعية للمراقبة والتصنيف. ولهذا فإن مسؤولية القائمين على الصناعة من تطبيقين وهيئات للرقابة كبيرة في العمل على إزالة الكثير من الغموض الذي يكتتف هذا المجال بتوضيح حقيقة المنتجـات، والعقبـات التي تعترض سبيل التطبيـق السـليم والخطـوات التي لتي

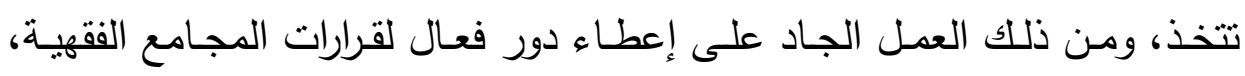
وللمعـايير التي صـدرت عن الهيئات المختصـة كهيئة المحاسبة والمراجعـة في البحرين، أو مجلس الخدمات في ماليزيـا فيمـا يتعلق بمعايير كفايـة رأس المسال، والحوكمة وادارة المخاطر، لأن منطلق وأساس العمل لهذه المؤسسات مرتبط بهذا؛

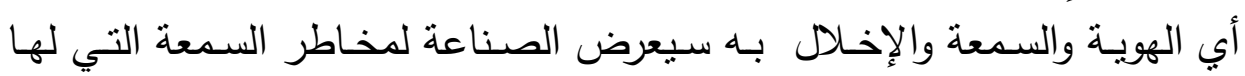
آثارها وأبعادها على الحاضر والمستقبل. ومن جهة أخرى فإن الابتعاد عن المبادئ

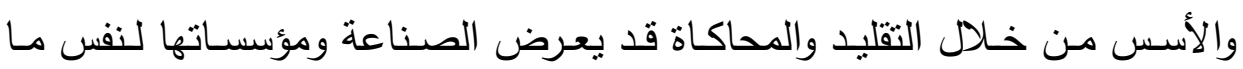

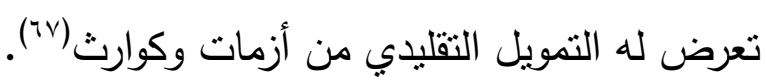

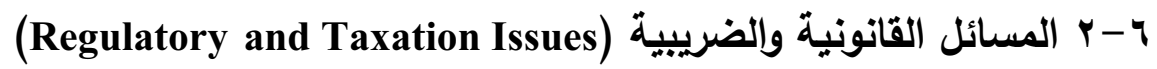
تعتبـر القضـايا القانونيـة والضـريبية مـن أهـم التحـديات التي تواجـهـ إقامـة مؤسسات تمويلية إسـلامية في البيئات التقليديـة، وذلك لعدم تعامل السلطات مـع هذا النوع من التموبل الذي يقوم على مبادئ وأسس - تختلف كما ذكرنـا سـابقًا-

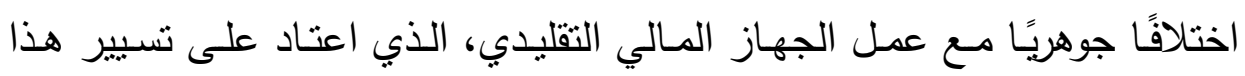

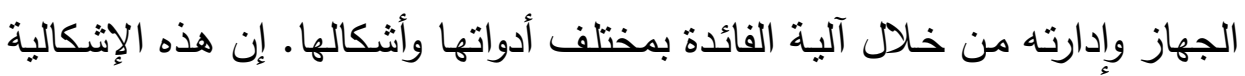

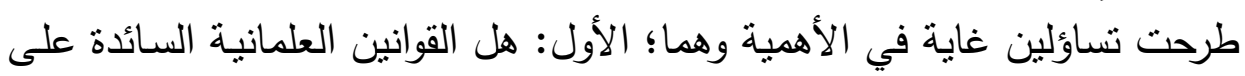
استعداد لاحتضان تمويل قائم على أساس ديني؟ والثاني: هل تخضـع المؤسسات التمويلية الإسلامية لنفس القواعد الاحترازية التي تخضع لها نظيرتها التقليدية؟ أم المئ

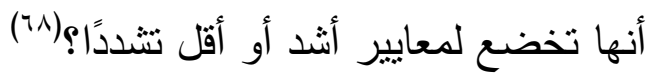

Thomas, R. (2010) "Islamic finance may "return to roots"'. (TV) Hesse, et al., (2008) "Trends and Challenges in Islamic Finance", p. 179. ( 
ونظرًا لمـا بطرحه التسـاؤلان السـابقان من مسائل ذات أبعاد قانونية، وتشـريعية، وثقافية بالنسبة لجهات الإشراف التقليدية لهذا يلاحظ أن اهتمام السلطات البريطانية بالتموبل الإسـلامي قديم(797) إلا أن الثروع في التعامل مـع بعض مسائله القانونية والضريبية لم يشرع فيه إلا مؤخرًا من خلال مجلس الخبراء الذي تشكل لهذا الغرض ومـن خـلال الجهـات الحكوميـة المسـؤولة؛ وزارة الماليـة (Treasury)، ومصــلحة الضـرائب (Inland Revenue)، والجمـارك (Customs \& Duties)، وقـد أبـدت هـذه الجهـات اسـتعدادها للسـماح بتطـور التمويـل الإســامي عبـر السـنوات الثمانيـة الماضية من خلال التغيير في بعض التشربعات المتعلقة بالضرائب. والهدف من هذه التغييرات هو مسـاعدة التمويـل الإسـلامي على التطور والنمـو، وذلك بازالـة حالـة عـدم اليقين (Uncertainty) مسن نوايـا هـذه الجهـات، بالموازنـة وفـق مبـدأ

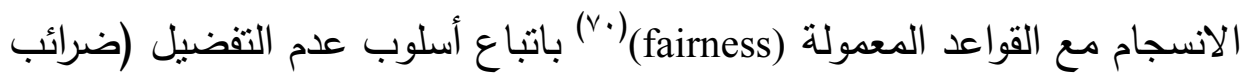

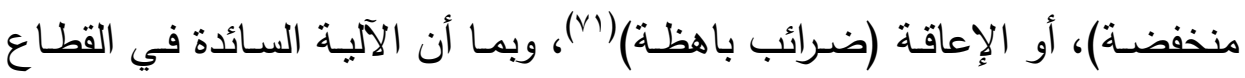
التقليدي لجذب واستخدام الأموال هي الفائدة فإن صيخ التمويل الإسلامي ومنتجاته عوملت كما لو كانت قائمسة على أساس الفائدة as if it were interest based) instruments) المنتجات التمويلية الإسلامية بالمبادئ التالية(Vr):

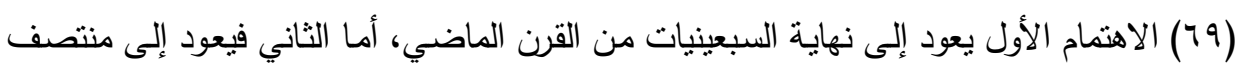

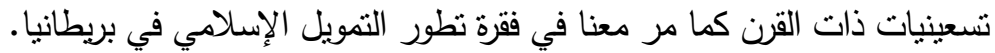

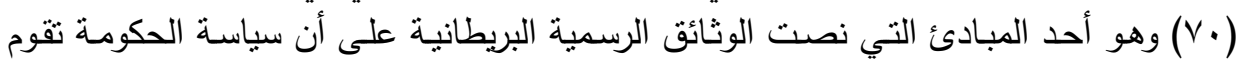

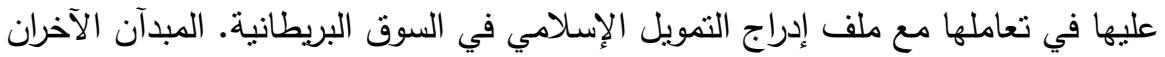

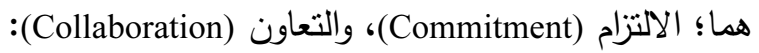
HM Treasury (2008) "The Development of Islamic Finance in the UK: the Government's Perspective", p. 5.

HM Treasury (2008) "The Development of Islamic Finance in the UK: the (VT) Government's Perspective", p. 15. 
• بناء المعالجة على الغرض أو الجوهر الاقتصادي (Economic substance) للعملية بدل التركيز على النواحي الإجرائية أو الثكلية التي تولى لهائل لها الأهمية

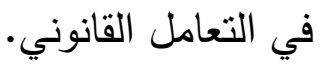
• المعالجة يجب أن تتم على نفس الأساس الذي عوملت بـه الأدوات التقليدية الممائلة القائمة على الفائدة (interest).

• تطبيق القواعد الضريبية السائدة منى ما كان ذلك ممكنًا.

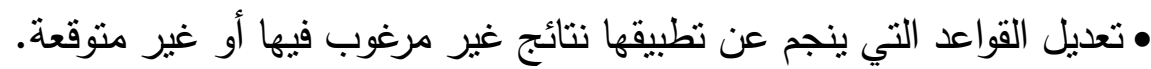
ما الذي تحقق حتى الآن؟

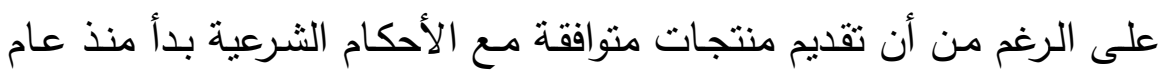

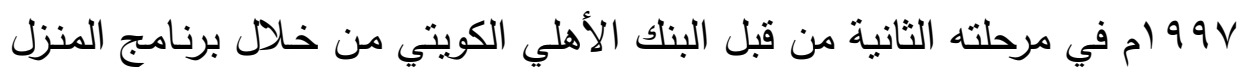

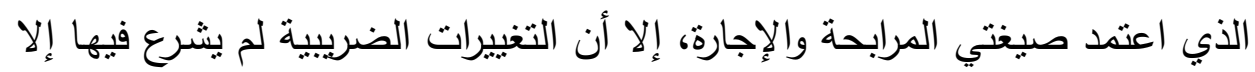

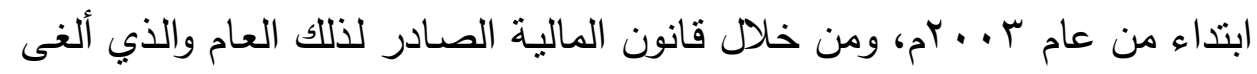

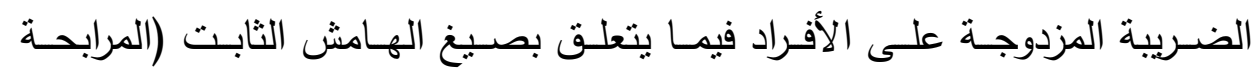

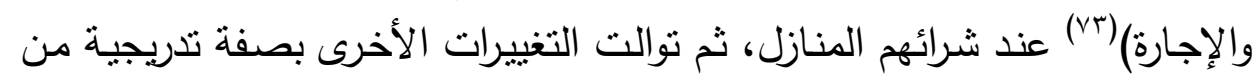

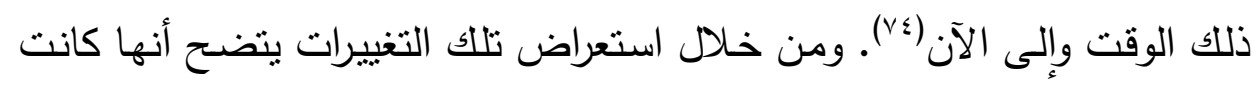
ضريبية أكثر منها قانونية.

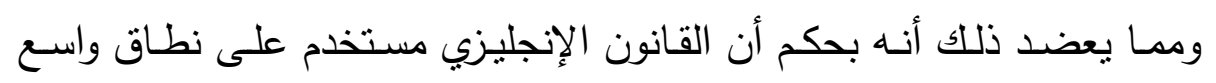

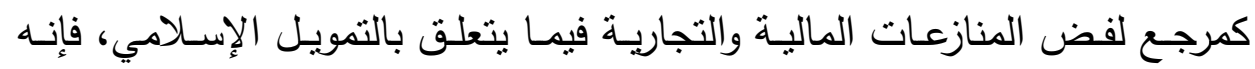

(VT)

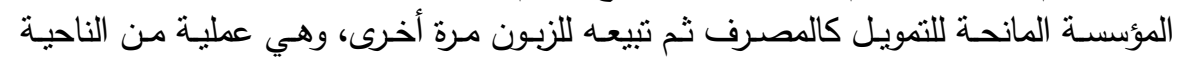

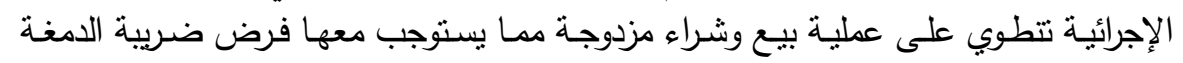

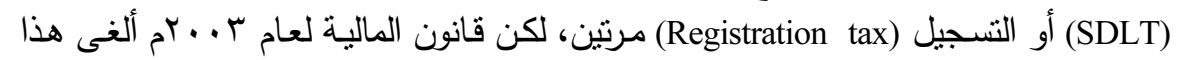

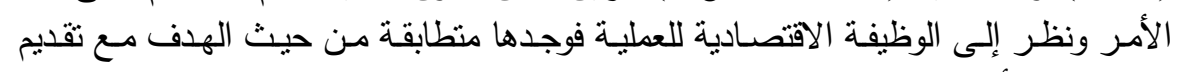

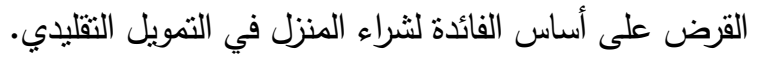

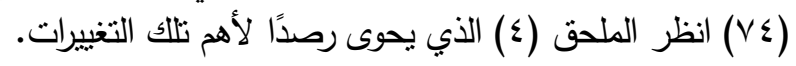


لوحظ مـن خـلال القضـايا التي عرضـت أن القضـاء يرجع للقانون الإنجليزي وإن تضمن العقد الرجوع للشـربعة، أو بما لا يتعـارض معها. ومن أمنلـة ذلك أنـه إذا

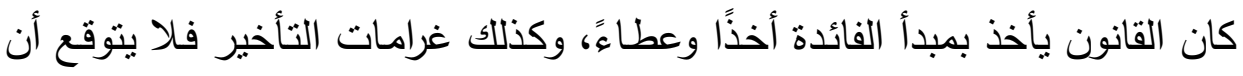
يلتزم القاضي بشرط تطبيق الشريعة الإسلامية المنصوص عليها في العقد(م0). وفيما يتعلق بالمستقبل فإن الحكومة ذكرت أنها:

ستواصـل مراقبـة التطـور فـي قطاعـات التكافـل (التـأمين الإســلامي)، والصـكوك؛ وفيمـا يتعلـق بالتكافـل فـإن الوثيقـة الصـادرة في نهايـة عـام ^ . . بام ذكرت أن قوانين التأمين التبادلي (Mutual Insurance) المطبقة كافية لتقنين نشاطات التأمين الإسلامي. مواصــلة العمـلـل مــن خــلال الجهــات الاستشــارية الرسـمية مثتـل لإزالـــة بعـض العراقيــل المتعلقـــة (Tax Technical Working Group) Capital) بالمنتجـات الأخرى، مثل ضـريبة أربـاح رأس مـال الصـكوك بلإك

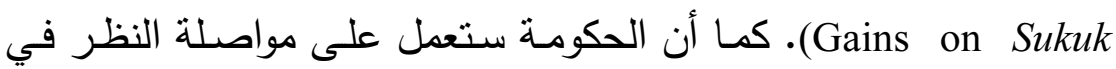
إمكانيـة إصـدار صـكوك سيادية مـن قبـل مكتب إدارة الدَّين العـام لتتويع مصادر الاقتراض والتقليل من تكاليفها، وستعيد النظر في تقديم خدمات التجزئة في السوق البربطانية متى ما قامت بإصدار الصكوك السيادية أو

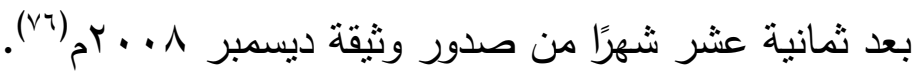

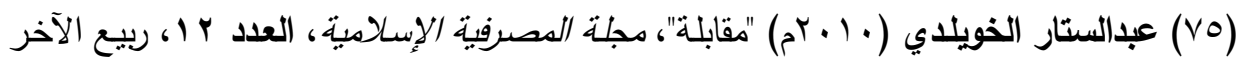

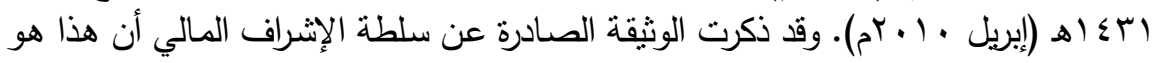

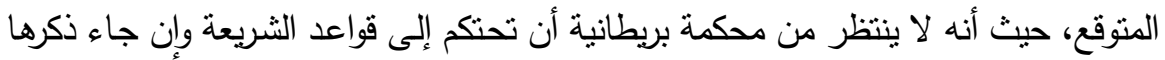

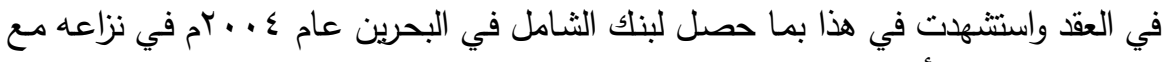
شركة بيكسيمكو للأدوية: في في في Ainley, M., et al., (2007) "Islamic Finance in the UK: Regulation and Challenges", p. 17. HM Treasury (2008) "The Development of Islamic Finance in the UK: the (V7) Government's Perspective", p. 12. 


\section{7-r - غياب المعايير الموحدة (Lack of Standardization)}

إن غياب معايير عامة مقبولة فيما يتعلق بالمنتجات والتطبيقات العملية لأيـة صـاعة من شـأنه أن بعـوق تطورهـا، وذلك بتأثنيره على قدرتها النتافسية وزيـادة

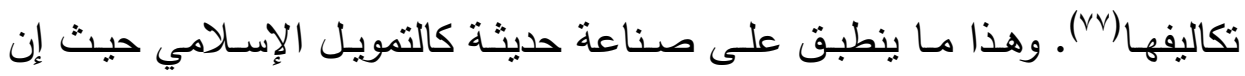
غياب المعايير الثرعية والمحاسبية العامـة والمتفق عليها من جميع الجهات، أي العالميـة، كما هو الثـأن في التمويـل التقليدي يؤثز من غير شـك على انتشـارها

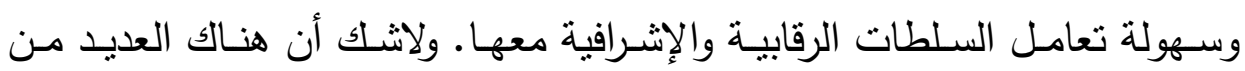

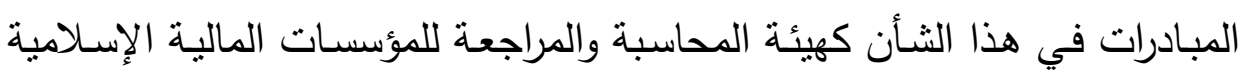
في البحرين، أو مجلس الخدمات الإسلامية (AAOIFI)

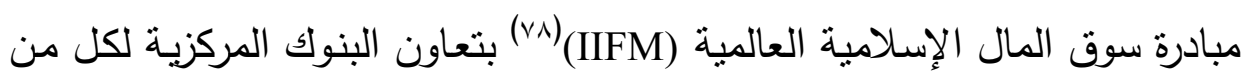

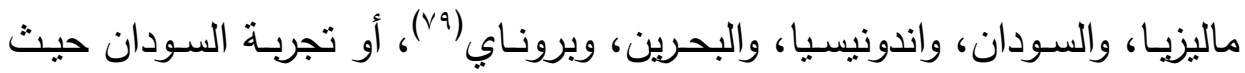

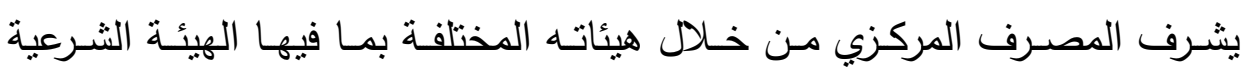
الموحدة مما يحقق قدرًا من الانسجام. إلا أن الإشكالية في هذه المبادرات هي أنها

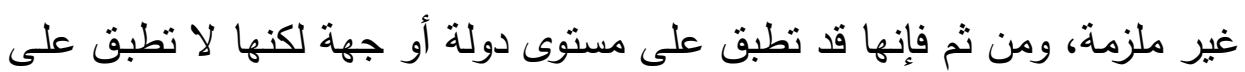

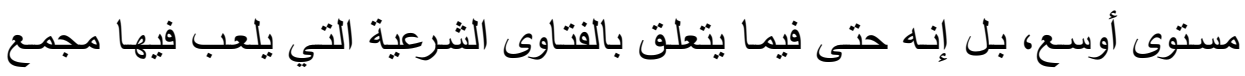

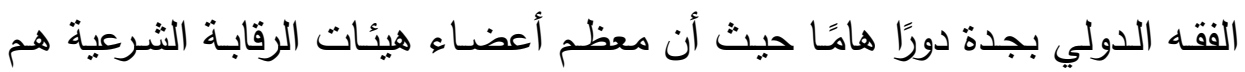

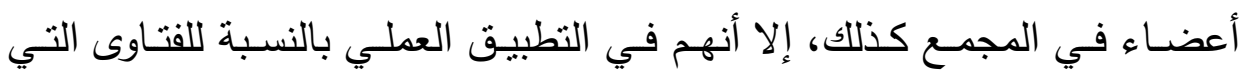

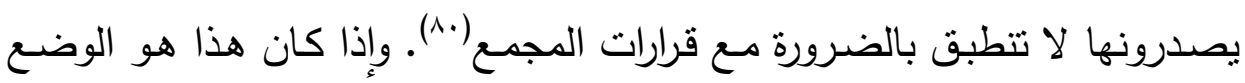

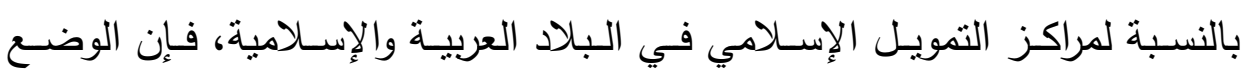
بالنسبة للبلاد غير الإسلامية قد يكون أعقد.

$$
\begin{aligned}
& \text { Ibid, p. 19. ( } \mathrm{VV}) \\
& \text { International Islamic Financial Markets (IIFM). ( } \mathrm{N} \text { ) }
\end{aligned}
$$

HM Treasury (2008) "The Development of Islamic Finance in the UK: the (V9) Government's Perspective", p. 20.

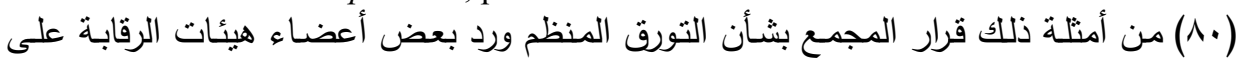

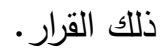




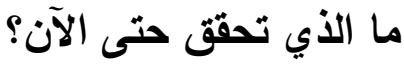

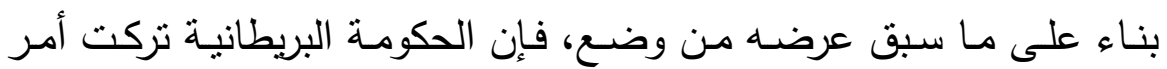
الأخذ بالمعايير الشرعبة والمحاسبية الصادرة عن هذه الجهة أو تلك منوطًا بشكل

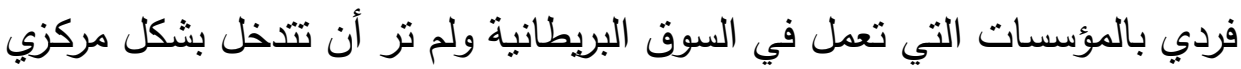

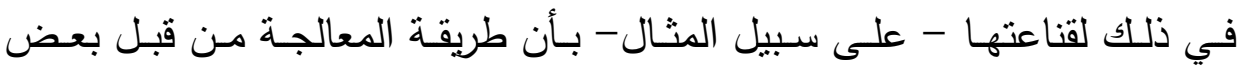
الجهات منل ماليزيا حيث تدخلت الحكومة في إلزام جميع العاملين بمعايير موحدة

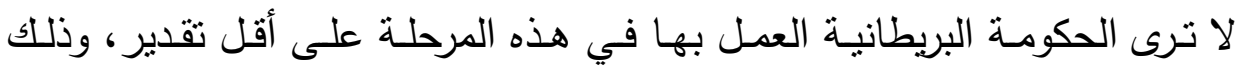

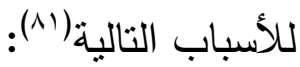

\section{(1) الهيئات القانونية في بريطانيا علمانية وليست دينية.}

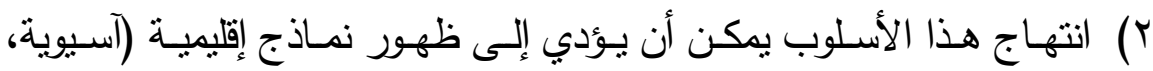

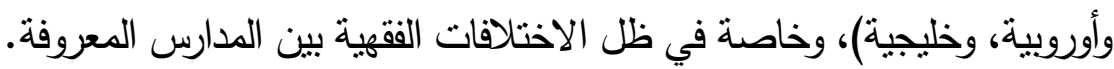
r) إتباع نظام معايير صارم، والقطاع لا يزال في طور النمو يمكن أن يحد

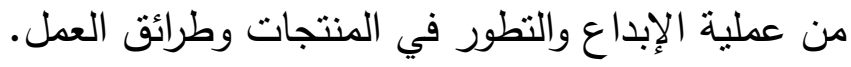

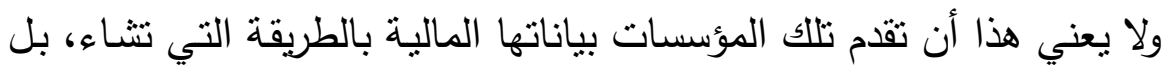
لابد من نوفر قدر معين من الوضوح والثفافية التي تسمح بالقراءة الصحيحة

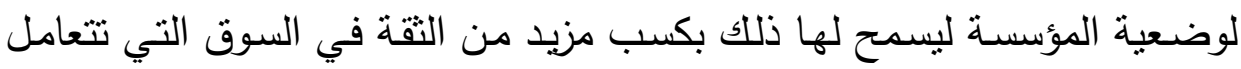

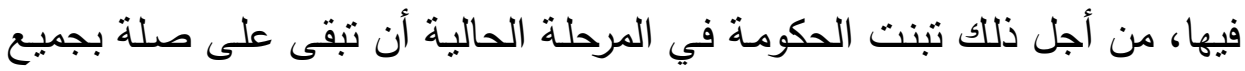

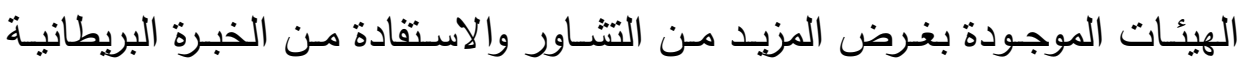

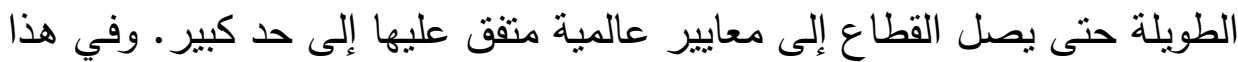

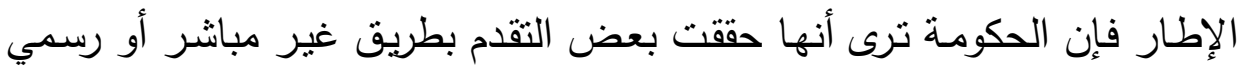

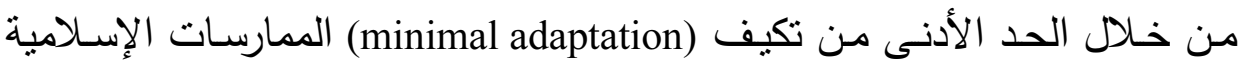

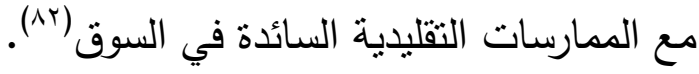

HM Treasury (2008) "The Development of Islamic Finance in the UK: the (^1) Government's Perspective", pp. 19-20. 
وفيما يتعلق بالمستقبل فإن المعطيات تتشير إلى استمرار الحكومة والأطراف

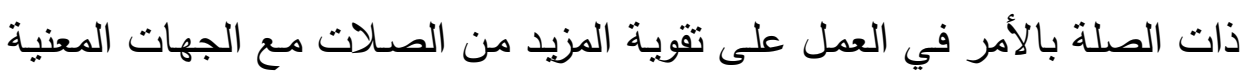

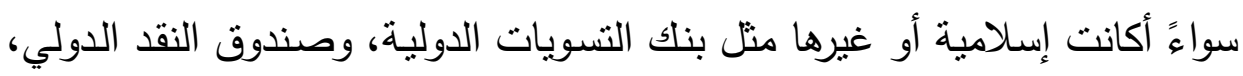

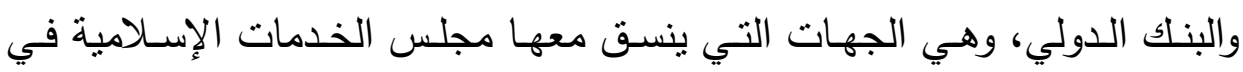

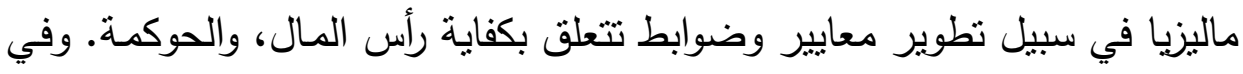

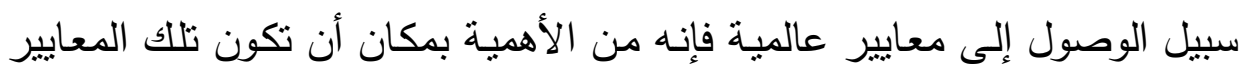

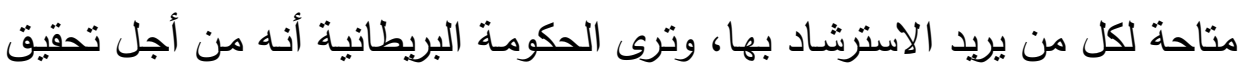
ذلك، فإنه يستحسن تصميم بطاقة الثروط (Term sheet) التي تتضمن الخطوات

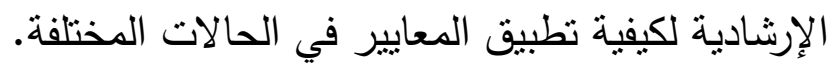

4- ؛ قلة الوعي والتعريف بالذدمات والمنتجات (Lack of Awareness)

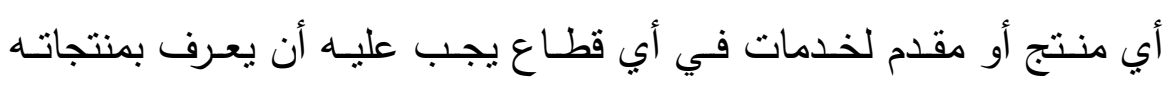

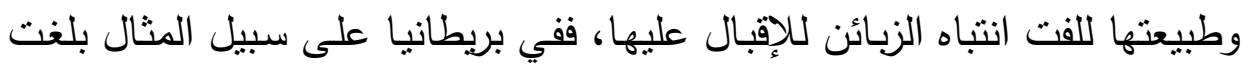

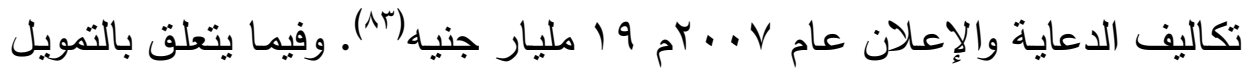

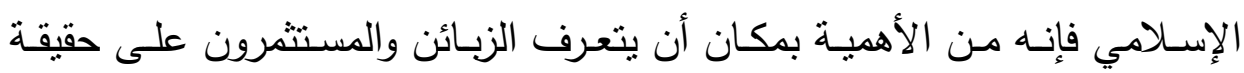

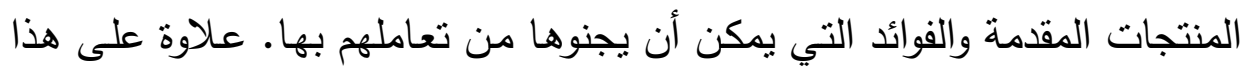

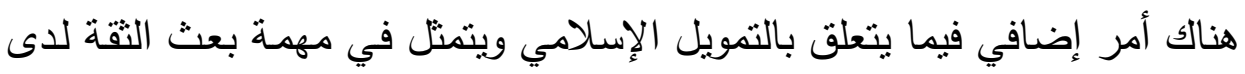

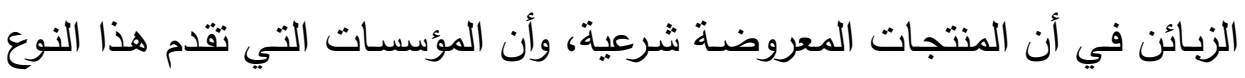
من الخدمات تتلقى نفس الدعم من الجهات الرقابية وتستقيد من الترتييات الموجودة

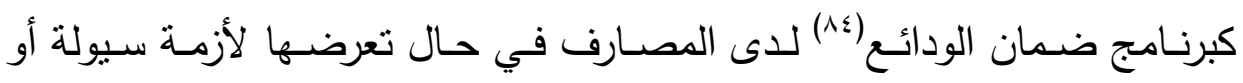
غبرها. - غيرا. 
ومـن جهـة أخـرى تؤكد الوثائق الرسـية على أهميـة الدعايـة للندن كمركز للتموبـل الإسـلامي في إطار التعربـ بالمنتجـات والخدمات التي يقدمها التمويـل الإسلامي في السوق البربطانية. ما الأي تحقق حتى الآن؟ • هنـاك مبـادرات منقدمـة جدًا قامـت بهـا بعض الجهـات الإسـلامية في بريطانيا، منثل المجلس الإسـلامي البريطاني (MCB)، ومجلس التمويل الإسـلامي في اسكتلندا (IFCUK) الذي أنشئ عام 0 . . بام بغرض التعربف والدعاية للتموبل الإسـامي. وقد نظم المجلس الأخير العديد من الأنشطة مثل تتظيم مؤتمرات أو ورش عمل موجهة لفئات مختلفة من أفراد الجاليـة المسلمة أو المجتمع كالأئمـة،

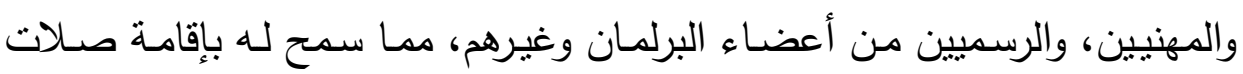

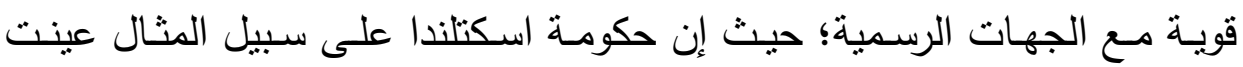
المجلس كهيئة اسنتـارية لها، وفي انجلترا تعـاون المجلس مـع مؤسسـة التجـارة وخدمات الاستثمار ببرامج منها على سبيل المثال البرنامج الثـامل لنأهيل العالم (Scholar) التقليدي في السوق البربطانية. • بـروز مزيـد مـن التعـاون والتتسيق بـين هذه الجهات والأطـراف الأخرى المعنية بالتمويل الإسلامي في المجتمع. • تمثنل دور الحكومـة في حضور العديد من الفعاليات التي تقام في لندن وغيرها، كما أنها تقوم عبر جهاز الرقابة على القطاع المالي؛ أي من خلال سلطة الخدمات المالية (FSA) بتوعيـة المواطن ببعض المنتجات من خلال موقع على (10) من الجهات الداعمة لهذا البرنامج بنك البحرين المركزي، والبنك المركزي الماليزي من

$$
\text { خلال مؤسسة إسرا البحثية (ISRA): }
$$

TheCityUK (2011) "Islamic Finance May 2011", p. 9. 


$$
\begin{aligned}
& \text { أحمد مهدي بلوافي وعبدالقادر حسين شاشي } \\
& \text { الانترنت (Money Made Clear Website) } \\
& \text { وفيما يتعلق بالمستقبل بمكن الإشارة إلى ما يلي: }
\end{aligned}
$$

• تحقيق مزيد من التعاون بين قطاع التمويل الإسـامي، والجالية المسلمة،

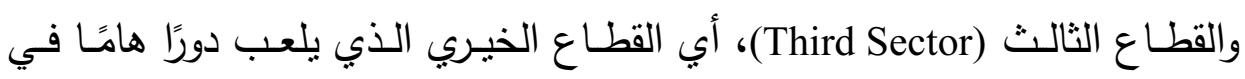
تقديم خدمات لا تستطيع مؤسسات السوق تقديمها. • التواصل مع قادة الجالية والمؤثرين فيها.

• استخدام الإعلام الثـبي مهم لأنه ليست هنالك تغطية كافية، وما يظهر في هذا النوع من الإعلام غير دقيق وسلبي، ومن الأمور التي قد يفكر في إقامتها مؤتمر خاص للإعلاميين، خاصـة المشتخلين في الإعلام الثـبي الذي لله تأثير لإنير بالغ على عوام الناس.

• أهمية الاستتاد إلى المعلومات الدقيقة والحديثة التي تعرض في المناسبات العامـة مثل المحاضـرات، والندوات وورش العمـل التي تنظم بخصـوص التعريف الته بالتموبل الإسلامي ومنتجاته. • نصائح موثوقة من قبل الجهات الرقابية لزبائن التمويل الإسلامي. • التزام الحكومـة ودعمها لتطور هذا القطاع من خـلال الأنشطة المختلفة

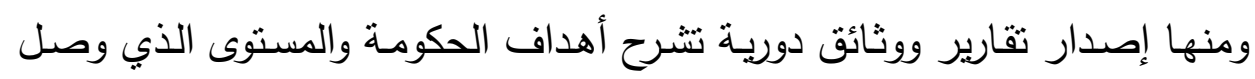
إليه تطور التمويل الإسلامي بشأن بعض القضايا.

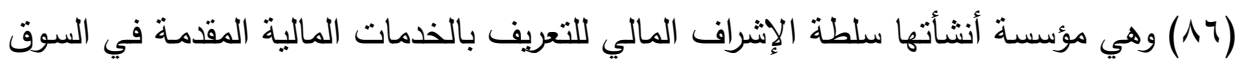

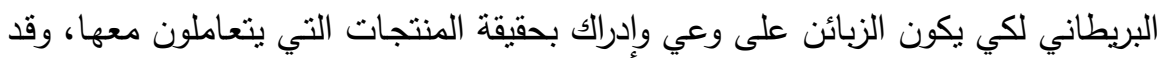

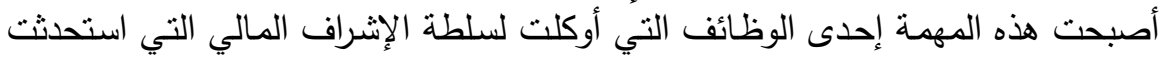

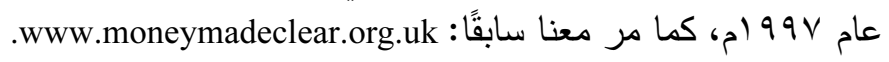


ج-ه قلـة الطاقـات البشـرية المؤهلـة بالمهـارات المناسبة والمنتجـات المتنوعـة (Lack of appropriate human skills and product diversification) هذا التحدي له ارتباط كبير بالتحدي الأول الذي نوفش في هذه الفقرة حيث إن توفر الطاقات المؤهلـة تأهيلاً مناسبًا والقادرة على خدمـة المؤسسـات التمويليـة الإسـلامية من الأهمية بمكان، وذلك أن معظم الكوادر البشرية التي تعتمد عليها

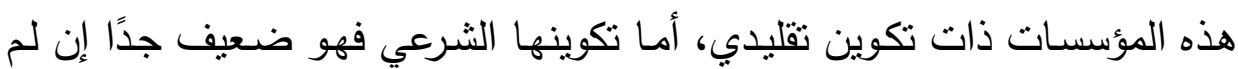

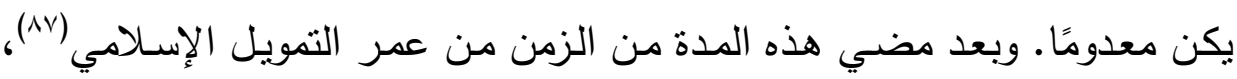
وبعد المبادرات المتعددة من خلال برامج التدربب والبرامج التعليمية على المستوى الجامعي أو على مستوى مؤسسـات مهنيـة متخصصـة فإن القضية لا تزال تؤرق أصحاب الصناعة والمهتمين بتطورها التطور الصحيح الذي يقدم الخدمات بكفاءة ويحافظ على الهوية الخاصة لهذا التمويل(^^).

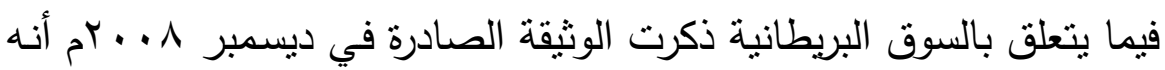
لا يبـدو أن هنـاك نقصًّا فـي الكـوادر البثـرية في الوقـت الحسالي تعـاني منــه المؤسسات التمويلية التي تقدم الخدمات المالية المتوافقة مع أحكام الثربعة، وبيدو أن الوثيقة نظرت من جانب الكم ولم تتظر من جانب النوع، فقد لا حظنا من خلال معاينة بعض الفروع التي تقدم هذا النوع من التمويل أنه عندما كنا نسأل

• (

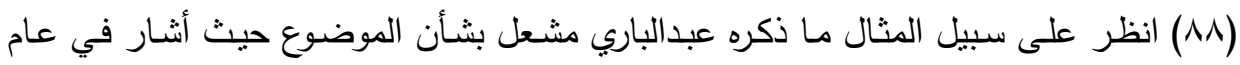

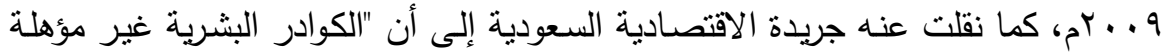

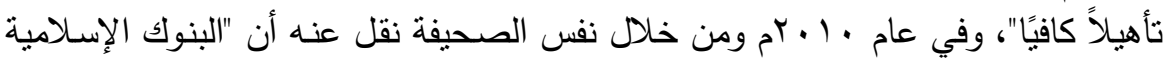

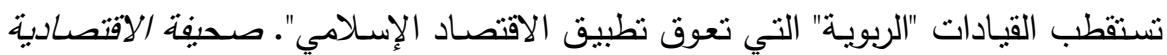

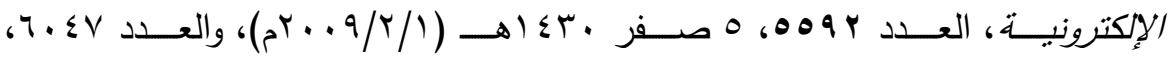

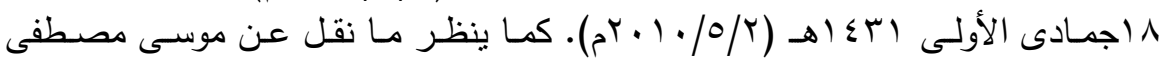

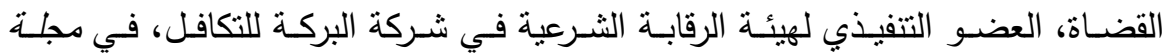

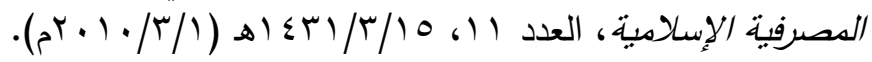


عن الجوانب الثرعية فإن أقصى ما يزودنا بـه الموظف هو أن المسؤول الفلاني

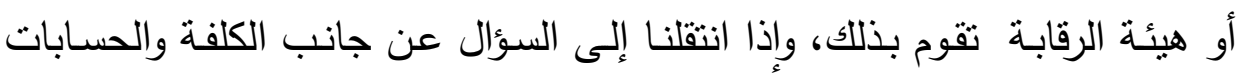

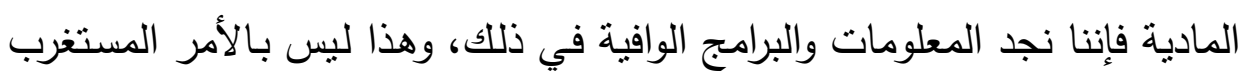
إذا نظرنا إلى الظاهرة في إطارها الكلي كما نقل اللصيقون بالصناعة من خلال المسؤوليات التي يقومون بها. وإن كان هنـاك من نقص حسب الوثائق الرسمية البربطانية فإنه واقع على مستوى علماء الثربعة الذين يجمعون بين علمي التموبل

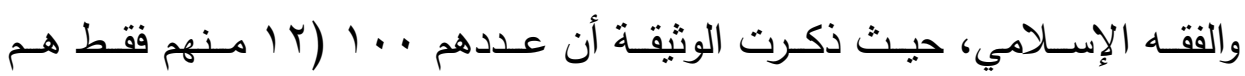
"المستخدمون بشكل مكثف؛؛ أي الذين تتكرر أسماؤهم في معظم الهيئات)(^هـ. وفي تقديم القضية واختزالها بهذا الشكل نظر حيث أثرنا في التحدي الأول إلى عدد من المسائل تتعلق بهذه الجزئية مـع محاولة البعض تقديم تقسيرات لها فكان أن أثير إلى مسألة الاحتكار ، وقانون "العملة الردئية تطرد العملة الجيدة"، وذلك

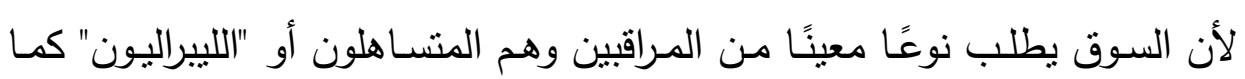

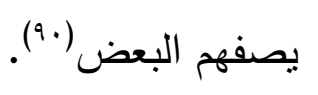
ما الأي تحقق حتى الآن؟ • هنالك برنامج من الحكومة (Leitch Review of Skills) والذي يسعى إلى الى

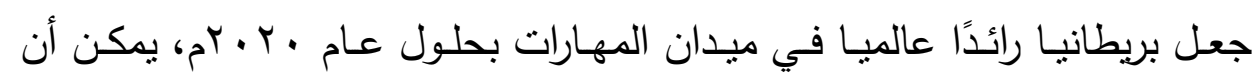
بستقيد منه التمويل الإسلامي كما تذكر الوثائق الرسمية.

HM Treasury (2008) "The Development of Islamic Finance in the UK: the

Government's Perspective", p. 26.

(9) من اللافت للنظر في هذا الثأن أن غير المسلمين يشيرون لهذا الأمر ونحن هنا لا نتكلم

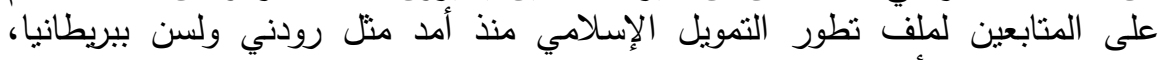

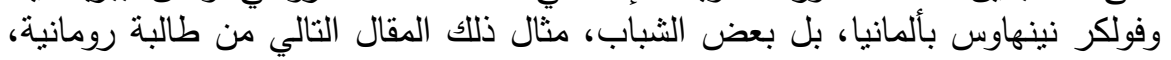

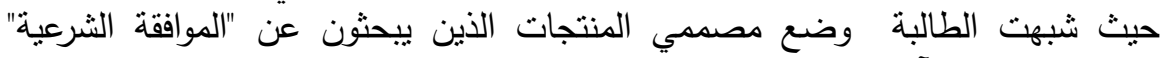

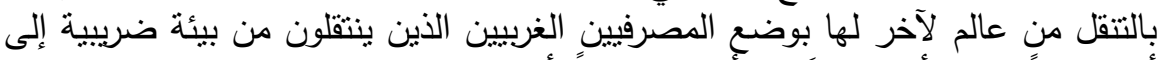

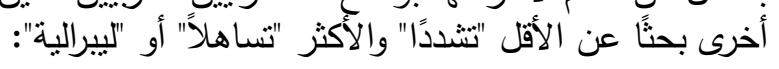

Sorina Aioanei (2007) “European Challenges for Islamic Banks”, p. 13. 


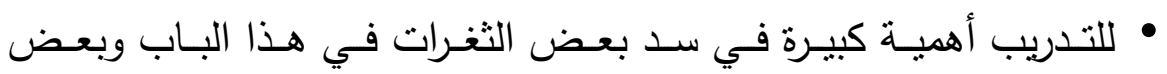
المؤسسـات البربطانيـة تقوم بـدور كبيـر في هـا. كمـا أن الحكومـة قامـت بطرح

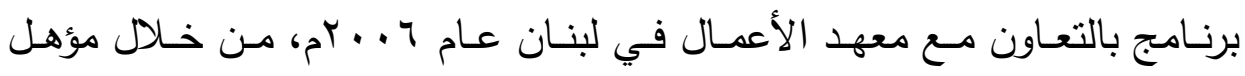
التمويل الإسـلامي (Islamic Finance Qualification)، وبعض الجهات الإسـامية تقوم بدور هام كذللك. كما أن الجهات الأكاديمية تقوم بجهود ومن خلال التتسيق

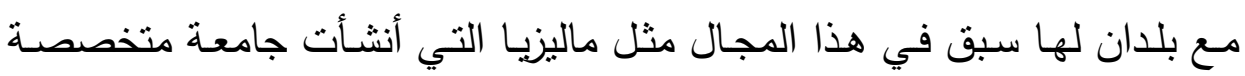
للتمويل الإسلامي برعاية البنك المركز الماليزي("9)، يمكن أن يتحقق بعض التقدم

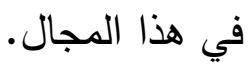

وفيما يتعلق بالمستقبل تؤكد الوثائق الرسمية أن المسؤولية الكبرى بخصوص

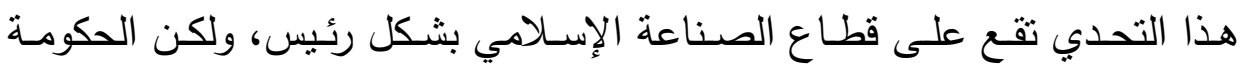
ستساعد من خلال ما لايها من برامج عامة فيما بتعلق بالتموبل، أو برامج خاصـة فيما يتعلق بالتمويل الإسلامي.

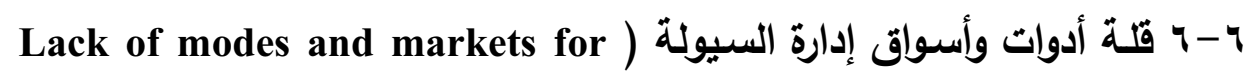

\section{.(liquidity management}

تمثل إدارة السيولة أحد أهم العناصـر التي تولى لها عنايـة خاصـة من قبل المؤسسات التمويلية بشكل عام، والمصرفية بشكل خاص، كما أن هذا الأمر يشكل

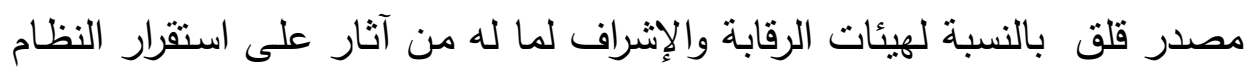

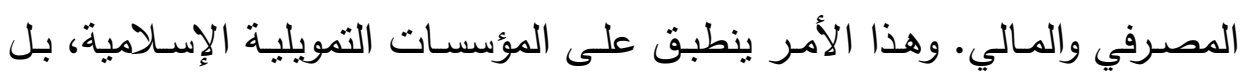
الموضوع يمثل مصدر إثنكال كبير حيث إن هذه المؤسسات لا تستطيع - بحكم المبادئ التي تقوم عليها- توظيف أموالها في الأدوات التقليدية ذات السيولة العالية كأذونات الخزانة، أو السندات قصيرة الأجل، أو الاعتماد على آليات إعادة الثراء

(9) تجسـ هذا من خـلال التعاون الذي أقامته جامعـة ريدينغ (Reading University) مـع مركز

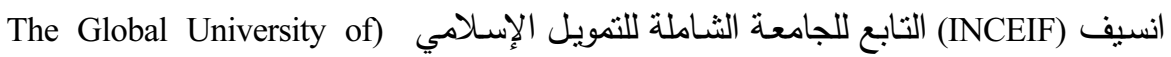

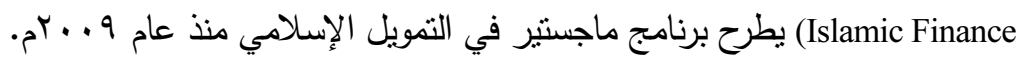


(repo) الجهاز المصرفي التقليدي يتمتع بسوق إقراض بين المصـارف غايـة في التطور والكبر من حيث الحجم والمرونة من حيث الآليات.

ولهذا فإن خيارات المصـارف الإسـلامية في هذا المجال محدودة حيث إنها تعمد إلى الاحتفـاظ بأرصـدة كبيـرة أو احتياطبـات معتبـرة، وهنـا تظهـر إثـكالية الفرصة الضائعة حيث أن إيداع هذه الأموال في المصارف التقليدية سيجعل منها

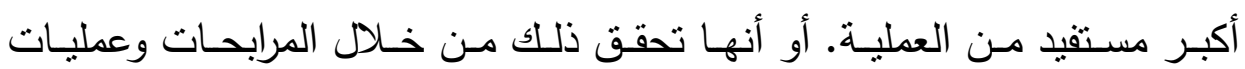
التورق(r9)، وهذه العمليات ثثور حولها الكثير من الثكوك لأنها صورية. وللتقليل

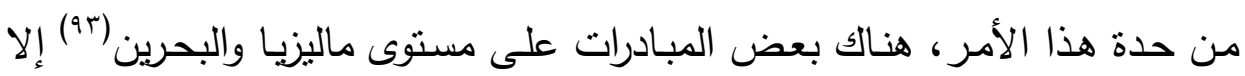

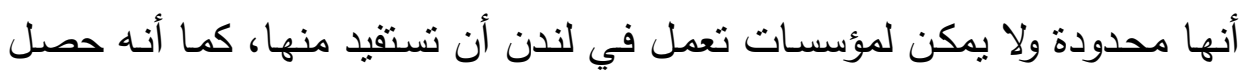
تطور في جانب الصكوك التي بلـغ عدد المتداول منها عشرون نوعًا من أنواع

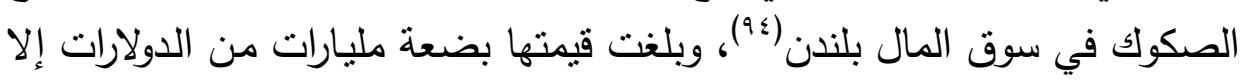

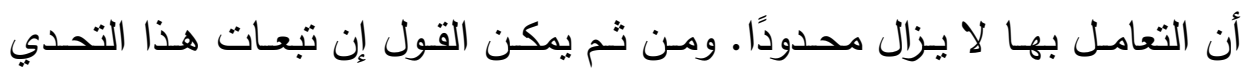
وتكاليفهـ في اللحظـة الراهنـة تقع بشـكل رئيس على كاهل المؤسسـات التمويليـة

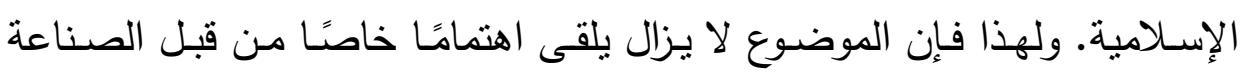

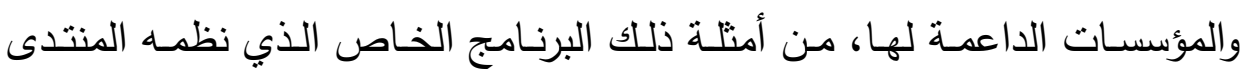
العالمي للتمويل الإسلامي في لقائه السادس بالتعاون مع المجلس العام للمؤسسات

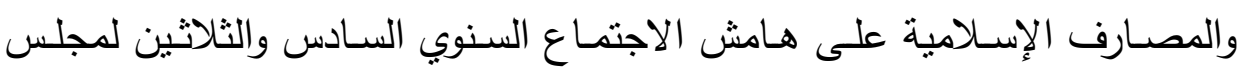

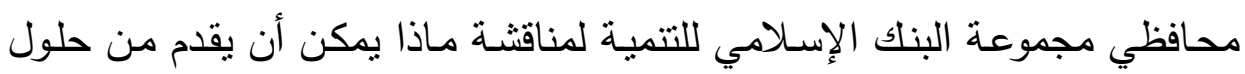
ومقترحات في هذا الصدد (90).

Ainley, M., et al., (2007) "Islamic Finance in the UK: Regulation and Challenges", p. 18. (9Y) Wilson, R. J.A. (2003) "Regulatory challenges posed by Islamic capital market (9r) products and services", p.5.

UK Trade \& Investment Services (2010) "Supportive Legislation Boosts UK's ( 9 ) World-Leading Islamic Finance Industry".

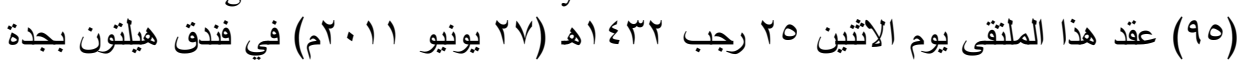
وشارك فيه مجموعة من الخبراء المحليين والعالميين. 
 Meeting the International Standards for capital adequacy requirements and risk management.

تمثل المعايير الدولية التي وضعتها لجنة بازل فيما يتعلق بكفاية رأس المال،

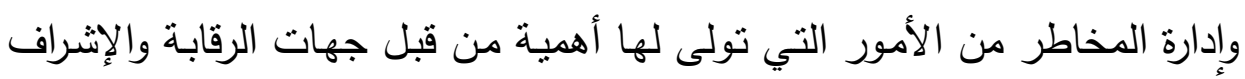

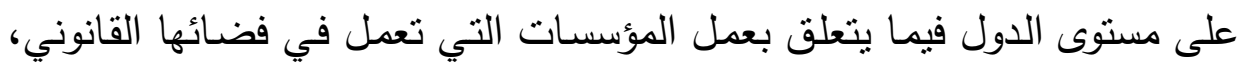

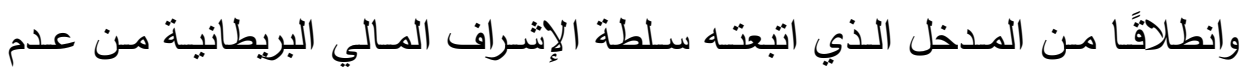

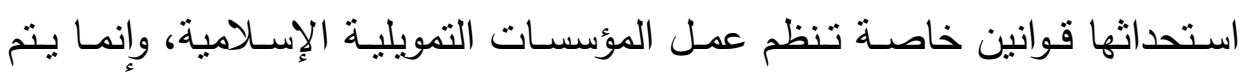

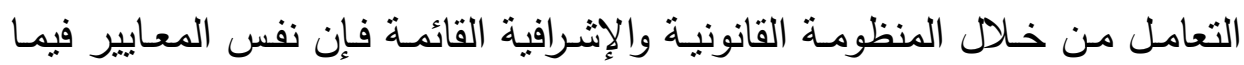
يتعلـق بكفايـة رأس المـال، وإدارة المخـاطر ســنطبق علـى المؤسسـات التموبليـة الإسـلامية، ومن ثم فإن السؤال الذي يطرح نفسه من خلاعل انتهاج هذا الأسلوب هو : هل يمثل تطبيق هذه المعايير وبنفس الطريقة السـائدة في التمويل التقليدي

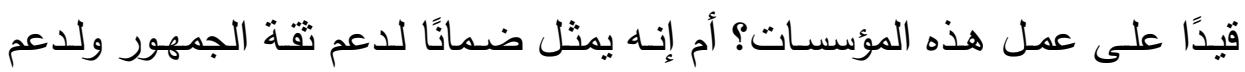
الاستقرار المالي في النظام؟ أسئلة يصعب الإجابـة عليها هاهنـا إلا أن ما يمكن تقريره هو أنـه إجراء لا يمكن تفاديـه في الوقت الحسالي، خاصـة في ظل أجواء الأزمـة الماليـة العالميـة، وما يمكن أن تعدل عليه المؤسسـات التمويليـة الإسـلامية هو محاولة إقناع سلطة الإشراف المالي بالأخذ قدر الإمكان بالمعايير التي طورها

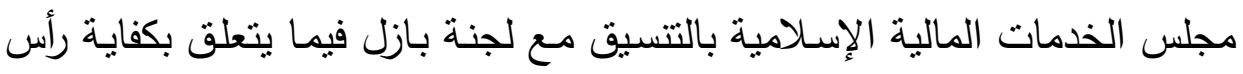
المال والتي أخذ فيها بعين الاعتبار خصوصية التمويل الإسلامي في هذا المجال.

\section{V - الخلاصة والنتائج}

سلطت الورقة الضوء في الفقرات السـابقة على أهم التطورات التي شهدها

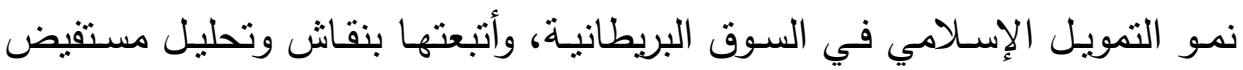
للفرض والتحديات لوجود هذا النوع من التمويل في بيئة تقليدية عربقة وعلى درجة

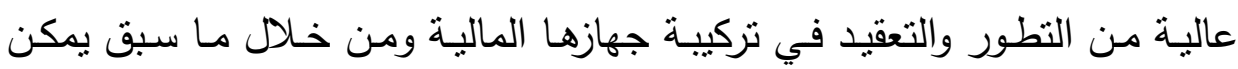

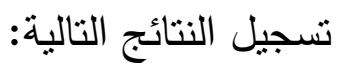


( ) اهتمام بريطانيا بالتمويل الإسـامي قديم، وهو مرتبط بأهداف إستراتيجية حددتها الحكومـة بتعزيز مكانـة لندن كمركز مالي عـالمي، وليس لهذه التطورات صلة بأثياء ظرفيـة كالأزمـة المالية، أو قناعة مبنيـة على دراسات توصلت فيها الحكومة إلى أفضلية التمويل الإسلامي على نظيره التقليدي، ومن أدلة ذلك امتتاع

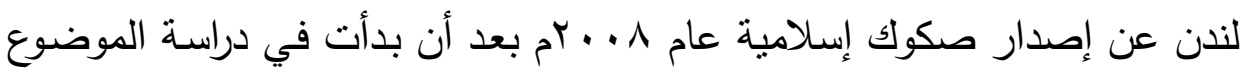

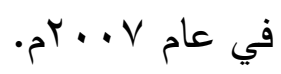

r) قطـع التمويـل الإسـلامي في بريطانيـا شـوطًا كبيـرًا، مسن حيـث الحجـم والمؤشرات الكمية الأخرى التي أثرنا إلبها، إذا ما قورن بما هو موجود ببلاد أخرى بـى

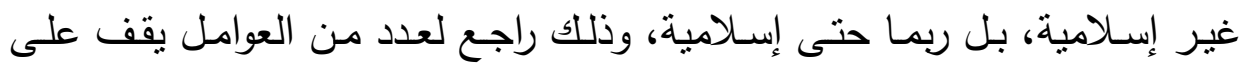

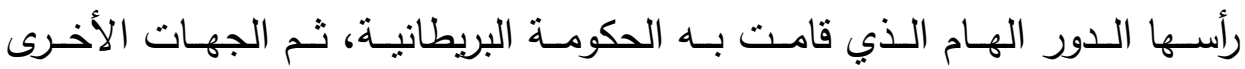
كمؤسسات الجالية المسلمة.

r) سار تطور التمويل الإسلامي في بريطانيا وفق أهداف إستراتيجية محددة،

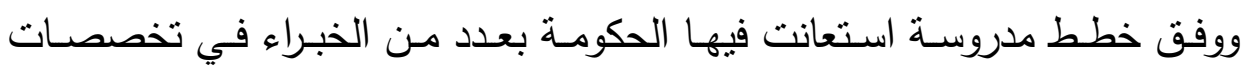
مختلفة. ومن الأساليب التي اعتمدت في هذا المجال التدرج في التعامل مع الصيغ،

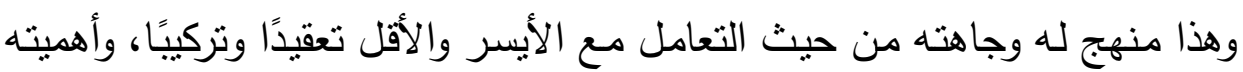
في السماح للجهات الإشرافية والرقابية بفهر كل منتج وأداة فهمًا شاملاً ودقيقًا. ع) لم تحدث تغييرات تتعلق بقانون المصارف (Banking Act) الذي يحدد هوية المؤسسـات المقدمـة للخدمات الماليـة كقبـول الودائع التي يجب أن تكـون مضـمونة بغض النظر عن استخداماتها المختلفة؛ تحت الطلب أم للاستثمار، الذي مسه التغيير هو قانون المالية (Finance Act) الذي أزال بعض العقبات الضربيية التي كانت تجعل من منتجات التمويل الإسلامي أكثر كلفة من نظيرتها التقليدية. 0) مفتاحسان رئيسـيان لتعامـل سـلطة الإشـراف البريطانيـة مـع ملـف إدراج التموبـل الإسـلامي في النظـام القائم وهمـا: الأول ويتمثنل في مـا اصـطلح عليـه 
وهو مفهوم يقصد به توفير الأرضية المناسبة للاعبين في (Level playing field) حقل معين لضمان تكافؤ الفرص في مجال التتافس، وفيما يتعلق بموضوعنا فإنه يراد به الخضوع لنفس القوانين من حيث وجوب الحصول على الترخيص لمزاولة

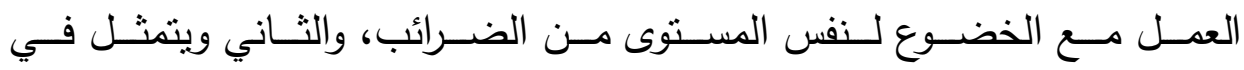
(as if it were interest) تقليدية مبنية على الفائدة، أي إن العائد الذي تدره أدوات التمويل الإسـلامي يعامل معاملة الفائدة من الناحية الضربيية.

7) التحدي الأكبر الذي يواجه انتشار التمويل الإسـلامي في البيئات التقليدية بشكل عام، والمتطورة منها بشكل أخص كالبيئة البربطانية، يتمثل في الحفاظ على يلى الهوبـة الخاصـة والمميزة لهذا التموبـل، بحيث بتطور التموبـل الإسـلامي بالطريقـة الصحيحة السليمة المرتبطة بأصول الاقتصاد الإسلامي، بدل التطور المبني على المعاملات الصورية والحيل التي تجعل منه مرتبطًا بالتموبل القائم ومقلدًا له في بلهي هندسة بعض منتجاته وأدواته.

V على الـرغم مـن أن السـلطات البريطانيـة أوضـحت أنهـا لا تتـدخل في المسائل الثرعة إلا أنها أكدت على مسألة الثفافية والوضوح في جميع المعاملات والمعلومات المقدمة من قبل المؤسسـات المالية لكي يكون الزبون على بينـة من أمره ولاعم التقة في الجهاز المالي.

^) التعامل مـع التمويل الإسـامي من قبل الجهات المسؤولة كتمويل ”بديل" وليس إسلاميًا، بديل هنا بمعنى إضـافة خيارات وفرص أخرى للمواطن البربطاني، وليس بديلا بمعنى أنه سيحل محل التمويل التقليدي.

9) من خـلال الوثائق الرسمية يلاحظ أن الحكومـة البريطانية تبعث برسائل تطمين للمواطن البربطاني العادي بأن الحكومة لن تعمد إلى استحداث تشربعات 
خاصة فيما يتعلق بالمسلمين سواءً أكان ذلك متصلاً بالمعاملات المالية موضوع دراستتا بشكل خاص، أو الأحوال الثخصية بشكل أعم. وهي لا تلام في ذلك لما لهذا الملف من حساسية ثقافية وسياسية تظهر بعض معالمها من خـلال بروز تيارات اليمين التي تتاهض وجود الأجانب بشكل عام والمسلمين بشكل خاص. كما أن استحداث قوانين من خلال الجهاز التشربعي، أي البرلمان والجهات المعنية الأخرى كمجس اللوردات، طريق شـاق وطويـل وقد يكون محفوفًا بمخاطر عدم المرور والتجربة الفرنسية مثال على ذلك.

\section{المراجع}

أولاً: المراجع العربية

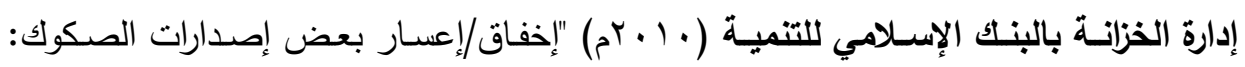

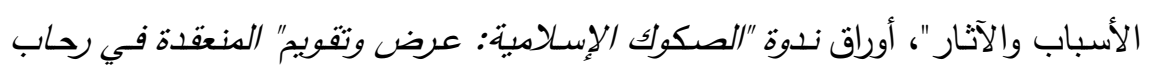

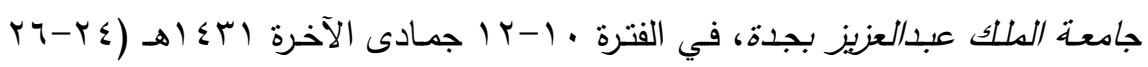

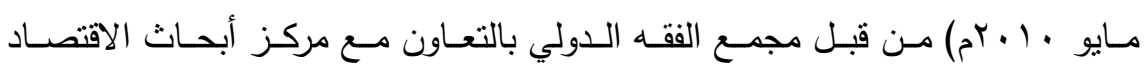

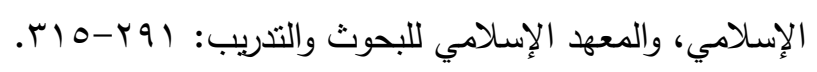

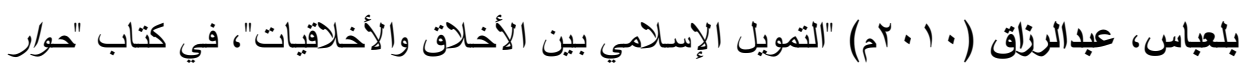

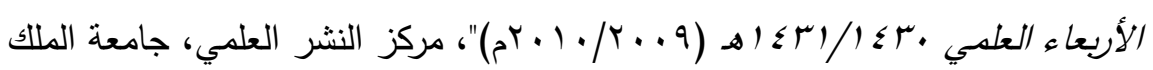

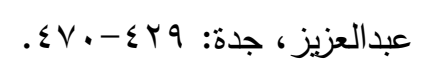

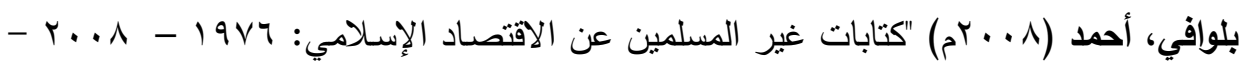

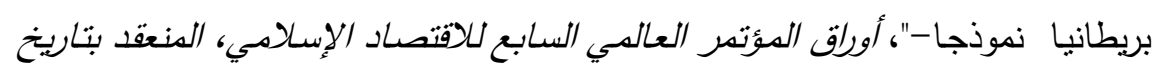

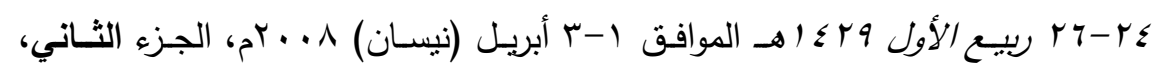
جامعة الملك عبدالعزيز :

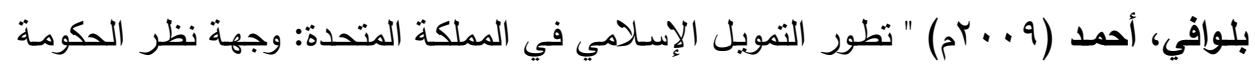

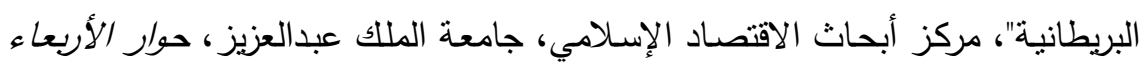

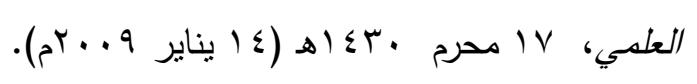


بلوافي، أحمد (• ( • rم) "لماذا تطور التمويل الإسـامي في بريطانيا أكثر من غيرها؟"، موقع

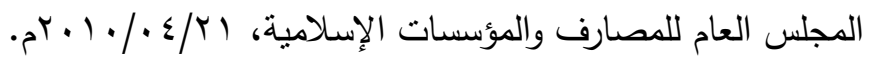

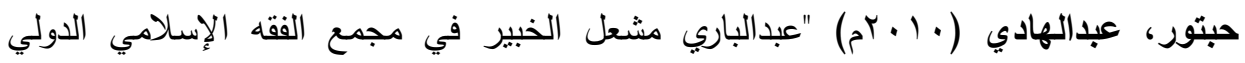
لـ"الاقتصادية": البنوك الإسلامية متهمة باستقطاب القيادات هالربويةه وإعاقة تطبيق

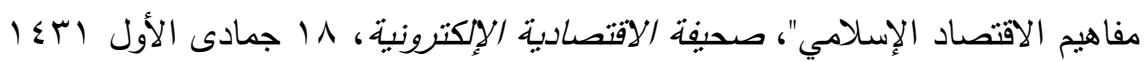

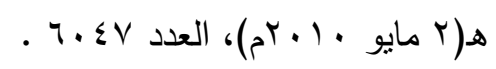

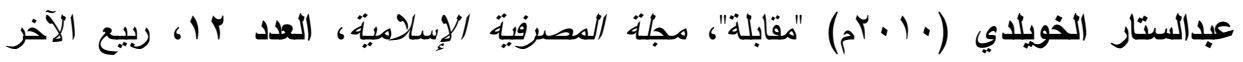

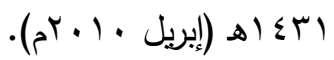

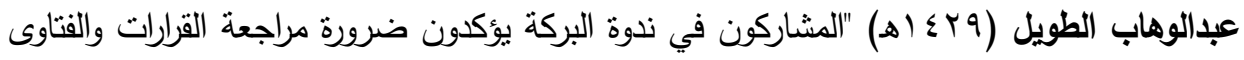

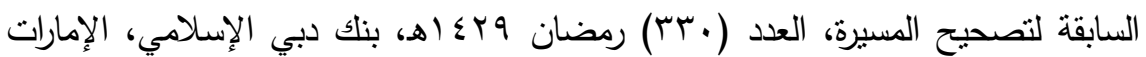
العربية المتحدة.

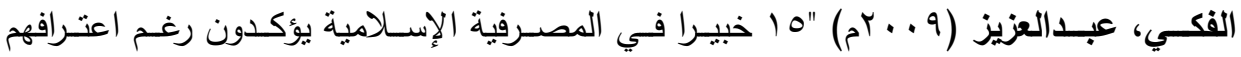

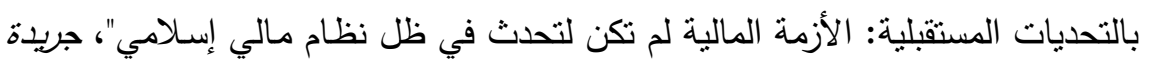

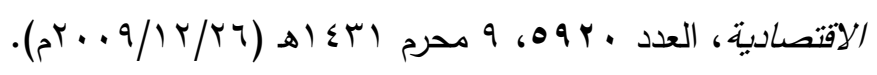

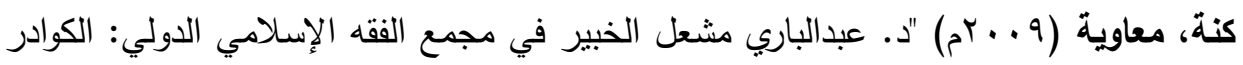

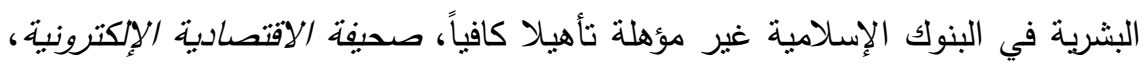

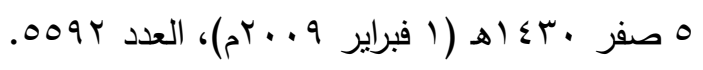

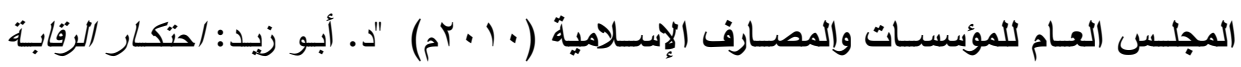

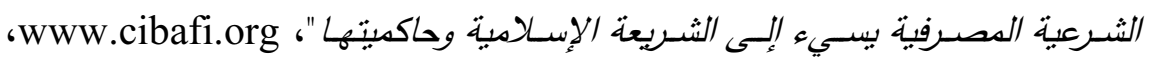
24/03/2010

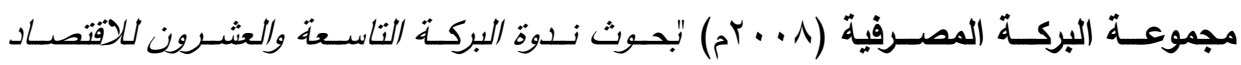

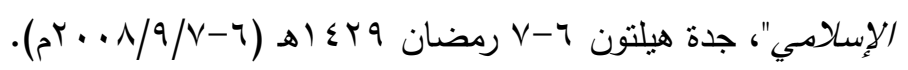

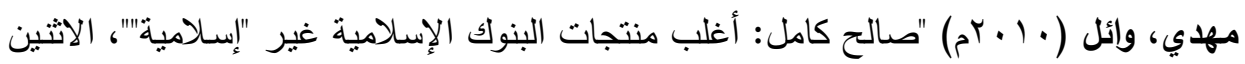

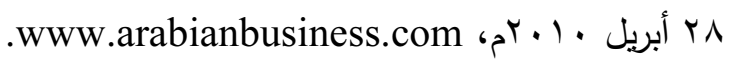




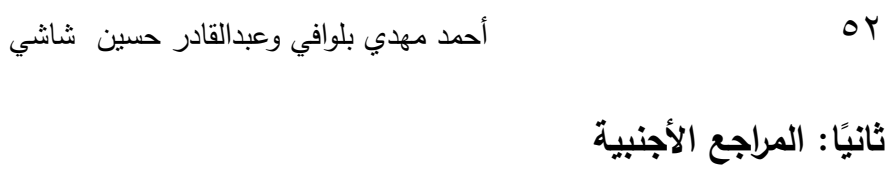

Ainley M.L; Mashayekhi A.; Hicks R.; Rahman A. and Ravalia A. (2007) Islamic Finance in the UK: Regulation and Challenges, Financial Services Authority.

Aioanei, S. (2007) "European Challenges for Islamic Banks", The Romanian Economic Journal, Year X, No. 25, bis, 7-20.

Arab Banker (2007) "Islamic Finance Opportunities and prospects in Europe", Arab Banker Autumn 2007, :51-52.

Asia Times (2008) "Halal insurance company launches in the UK", www.theasiannews.co.uk, July 30, 2008, accessed May 3, 2010.

Belouafi A. and Belabes, A. (2011) "Islamic Finance and the Regulatory Challenge: The European Case", forthcoming, in "Islamic Economics and Finance: A European Perspective", Jonathan Langton and Cristina Trullols (Ed), IE Business Publishing, Palgrave Macmillan, UK.

Belouafi, A. (2011) "Islamic Finance outside the Muslim World: The United Kingdom Experiment", forthcoming, "Les Cahiers De la Finance Islamique", Strasbourg Business School, No. 3, Strasbourg University, France.

Birch, T. (2010) "Islamic Finance Offshore: Present and Past", Islamic Finance News, March 3, 2010.

BMB Islamic (2011) “Global Islamic Financial Report (GIFR 2011)”, BMB Islamic publication, London, UK.

Buiter, W. (2009a) "Should you be able to sell what you do not own?", blogs.ft.com/maverecon, March 16, 2009.

Buiter, W. (2009b) "Islamic finance principles to restore policy effectiveness", blogs.ft.com/maverecon, July 22, 2009.

Dar, H.A. (2002) "Islamic Housing Financing in the United Kingdom: Problems, Challenges and Prospects", Review of Islamic Economics, No. 12, :47-71.

Gavin, J. (2010) "Islamic Insurers Eye Global Market", The Banker, 31 March, 2010.

Hesse, H., Jobst, A. A. and Solé, J. (2008) "Trends and Challenges in Islamic Finance", World Economics, 9(2): 175-193, April-June 2008.

HM Treasury (2008) "The Development of Islamic Finance in the UK: the Government's Perspective", HM Treasury, December 2008.

IFSL Research (2008) "Islamic Finance 2008", in Partnership with UK Trade \& Industry and the City of London, January 2008.

IFSL Research (2009) "Islamic Finance 2009", in Partnership with UK Trade \& Industry and the City of London, January 2009.

IFSL Research (2010) "Islamic Finance 2010", in Partnership with UK Trade \& Industry and the City of London, January 2010

Januja, N. (2010) "Is the Islamic Mortgage market dying a slow death?", www.islamicmortgages.co.uk, accessed May 9, 2010.

Langah, W.A. (2008) "Islamic Banking in the United Kingdom: Opportunities and Challenges", Msc Dissertation, Kingston Business school, Kingston University, October 2008. 
Leach, K. (2009) "Islamic Banking Developments in the Domestic UK Market", presentation made at: "Islamic Business: The Way Forward", a conference organized by Elshaarani Centre for Islamic Business and Finance (EIBF), Aston University, Birmingham, UK, June 2nd, 2009.

Masood, Omar, Chichti Jamel E., Mansour Walid, Amin and Qazi Awais (2009) "Role of Islamic mortgage in UK", International Journal of Monetary Economics and Finance, 2(3-4): 366-383.

Mathews, R., Tlemsani, I. and Siddiqui, A. (2003) "Recent Developments in the Market for Islamic Mortgages: Theory and Practice", Review of Islamic Economics, No. 14, : 49-68.

Open Society Institute (2009) "Muslims in Europe: A Report on 11 EU Cities", December 2009, Open Society Institute.

Parker, M. (2009) "UK Islamic Finance gets foothold in France", Arab News, 19 October 2009.

Ramkumer, K.S. (2010) "London remains centre for education, Finance: Lord Mayor", Arab News, 21/02/2010.

Raza, M.F. (2008) "The European Opportunity", Islamic Finance in Practice, Issue Two Autumn 2008, : 44-45.

Shaikh, O. (2010) "Development of Islamic Finance in the UK \& Europe", presentation made at the Inaugural event of El Shaarani Centre for Islamic Finance and Business, Aston Business School, January 11, 2010.

The Australian Trade Commission (Austrade) (2010) "Islamic Finance", The Australian Trade Commission, January 2010, Australia.

TheCityUK (2011) “Islamic Finance May 2011", TheCityUK's Islamic Finance Report, London, UK.

The Financial Services Authority (2007) "Speech by Clive Briault, Managing director, Retail Markets, FSA", Industry Forum, 17 October 2007, London, www.fsa.gov.uk, accessed 3 May 2010.

The Muslim Council of Britain (2009) "London and Islamic Finance: Briefing Paper for Mayor of London", February 2009.

Thomas, R. (2010) "Islamic finance may "return to roots"', Reuters, February 9, 2010.

UK Trade and Investment Services (2007) "The City- UK Excellence in Islamic Finance", November 2007, UK Trade \& Investment Services.

UK Trade and Investment Services (2010) "Supportive Legislation Boosts UK's World-Leading Islamic Finance Industry", www.ukinvest.gov.uk, accessed 03/05/2010.

Ünal, M. (2010) "Shariah Scholars- A Network Analytical Perspective", Funds@Work, April 2010.

Wilson R.J.A. (1999) "Challenges and Opportunities for Islamic Banking and Finance in the West: The United Kingdom experience", Thunderbird International Business Review, 41, Issue 4-5, : 421-444.

Wilson, R.J.A. (2003) "Regulatory challenges posed by Islamic capital market products and services", International Organization of Securities Commissions Organizations (IOSCO), Melbourne, February. 


$$
\text { أحمد مهدي بلوافي وعبدالقادر حسين شاشي }
$$

Wilson, R.J.A., (2007) "Islamic Finance in Europe", European University Institute For Muslim Minority in Europe (MUSMINE), Florance, Robert Schumann Centre for Advanced Studies, RSCAS Policy Papers 2007/02.

Wilson, R.J.A, (2007) "Islamic banking - opportunity or threat?", Common Ground News Service (CGNews), 23 January 2007, www.commongroundnews.org, accessed May 11, 2010.

Wilson, R.J.A. (2007) "Regulatory Challenges Facing the Islamic Finance Industry", Journal of financial transformation, The Capco Institute, : 140-143.

Wilson, R.J.A. (2009a) "Islamic Finance in Europe", Banca d'Italia, Seminar on Islamic Finance, November 2009, Rome.

Wilson, R.J.A. (2009b) "Why Islamic Banking Is successful?", www.islamonline.net, February 15, 2009. 


\section{ملحق رقم (1)}

لمحة عن المؤسسات التمويلية الإسلامية التي منحت ترخيصًا للعمل في بريطانيا.

\begin{tabular}{|c|c|c|c|c|c|}
\hline طبيعة العمل & المساهمون & الزيائن & الفروع عدد & النشأرة & اسم المصرف \\
\hline 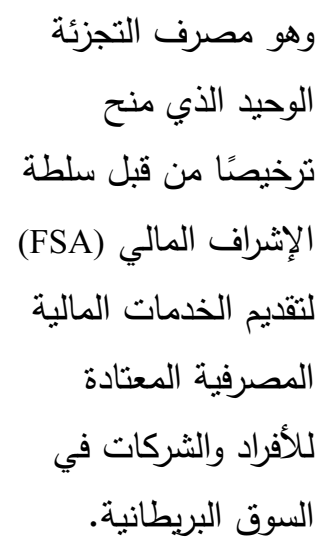 & رن المساهمين & • ه ألف & $\wedge$ & ع · & $\begin{array}{c}\text { البنك الإسلامي } \\
\text { البريطاني } \\
\text { Islamic ) } \\
\text { Bank of } \\
\text { (Britain }\end{array}$ \\
\hline مصرف استثماري & & -- & -- & Tr. T & $\begin{array}{r}\text { الإسبلك الاستثمار } \\
\text { الأوروبي (Bank } \\
\text { European } \\
\text { Islamic } \\
\text { Investment } \\
\text { (Bane }\end{array}$ \\
\hline 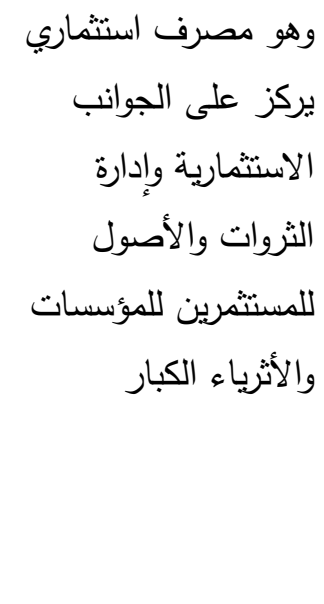 & 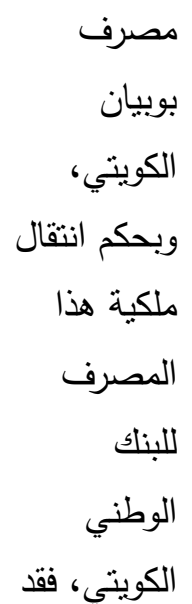 & -- & -- & $b^{r \cdots v}$ & $\begin{array}{c}\text { بنك لندن } \\
\text { والثرق الأوسط } \\
\text { Bank of ) } \\
\text { London and } \\
\text { (Middle East }\end{array}$ \\
\hline
\end{tabular}


أحمد مهدي بلوافي وعبدالقادر حسين شاشي

\begin{tabular}{|c|c|c|c|c|c|}
\hline & لهبح لهرف & & & & \\
\hline متخصرف استثمار في إلثارة & & -- & -- & 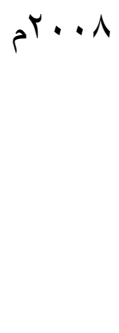 & $\begin{array}{c}\text { هنك غيت } \\
\text { Gatehouse ) } \\
\text { (Bank }\end{array}$ \\
\hline مصرف استثماري & فرع تابع & -- & -- & $r . \wedge$ & $\begin{array}{c}\text { بيت التموبل } \\
\text { European ) } \\
\text { Finance } \\
\text { (House }\end{array}$ \\
\hline توفير خدمة التأمين & $\begin{array}{c}\text { فرع من بركة } \\
\text { برنسبيل } \\
\text { (Insurance } \\
\text { Principle ) }\end{array}$ & -- & -- & A • • & $\begin{array}{c}\text { شركة السلام } \\
\text { Salaam ) } \\
\text { Halal } \\
\text { (insurance }\end{array}$ \\
\hline
\end{tabular}

IFSL, Islamic Finance 2010, p. 3; Wilson 2009a, IBB, Website. :

Asia Times (2008) "Halal insurance company launches in the UK", (97) www.theasiannews.co.uk July 30 (2008) accessed May 3, 2010. 


\section{ملحق رقم (r)}

\section{تعريف ببعض المنتجات المالية الإسلامية المقدمة في السوق البريطانية.}

\begin{tabular}{|c|c|c|}
\hline المؤسسة المقدمة للمنتج & الاستخدام & اسم المنتج \\
\hline البريطاني الإسلامي & لجذب مدخرات الأفراد لغرض & $\begin{array}{l}\text { الأجل ( مساب وديعة محدد } \\
\text { Fixed Term } \\
\text { (Deposit Account }\end{array}$ \\
\hline البريطاني الإسلامي & 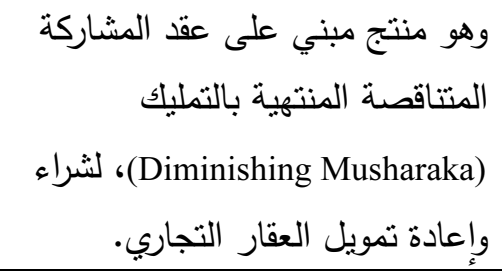 & $\begin{array}{r}\text { تمويل العقار } \\
\text { Commercial ) } \\
\text { (Property Finance }\end{array}$ \\
\hline البريطاني الإسـالمي & كالحساب الجاري في المصارف & (Current Account) \\
\hline 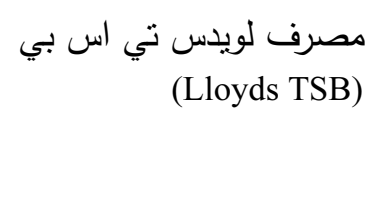 & لجذب القيئة الثراعد الثرعية كما وافقت الأفراد واستخدامها عليها & $\begin{array}{r}\text { الحساب الإسلامي } \\
\text { (Islamic Account) }\end{array}$ \\
\hline مصرف لويدس تي اس بي & قي قيل في الحساب المذكور أعلاه إلا أنه & $\begin{array}{l}\text { الحساب الإسلامي } \\
\text { Islamic للطالب } \\
\text { Student Account }\end{array}$ \\
\hline بريطانيا وبأموال محلية المستشرين في & بطاقة ائتمان مسبقة الدفع & $\begin{array}{r}\text { قرطبة ماسنز كارد } \\
\text { (Master Card) }\end{array}$ \\
\hline 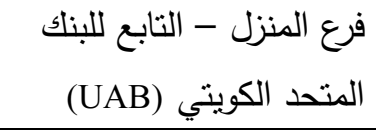 & لشراء المنازل & $\begin{array}{r}\text { برنامج المرابحة } \\
\text { (Murabaha Plan) }\end{array}$ \\
\hline 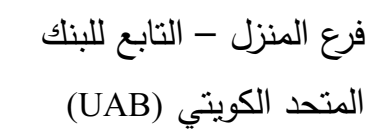 & لشراء المنازل & $\begin{aligned} \text { برنامج الإجارة } \\
\text { (Ijara Plan) }\end{aligned}$ \\
\hline مؤسسة البراق التابعة & لجذب مدخرات الأفراد بما لا يقل عن & برنامج البراق لحساب \\
\hline
\end{tabular}




\begin{tabular}{|c|c|c|}
\hline $\begin{array}{r}\text { للمؤسسة العربية المصرفية } \\
\text { (ABC Bank plc) }\end{array}$ & خمسمائة جنيه لمدة خمس سنوات & $\begin{array}{r}\text { الادخار المتوافق مع } \\
\text { (The } \\
\text { alburaq Shariah } \\
\text { Compliant Savings } \\
\text { Plan) } \\
\end{array}$ \\
\hline 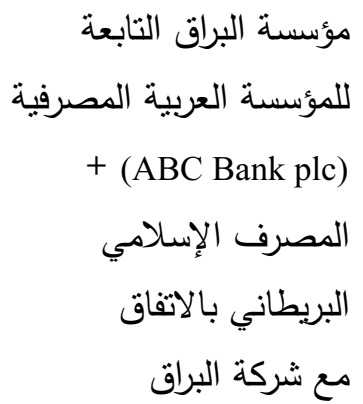 & وهو منتج مبني على عقد المشاركة & $\begin{array}{r}\text { منتج البراق المتوافق أحكام الثربعة } \\
\text { لشراء المنازل } \\
\text { (alburaq Shariah } \\
\text { compliant home } \\
\text { finance) }\end{array}$ \\
\hline
\end{tabular}

المصــدر: المواقـع الإلكترونيــة للمؤسســات المشــار إلبهــا فــي الجـدول، تـاريخ الزيــارة، $\cdot r^{r} \cdot 1 \cdot 1 \cdot 0 / 1$ 
ملحق رقم (r)

مؤسسات تعليمية بريطانية عليا تقدم برامج في التمويل الإسلامي

\begin{tabular}{|c|c|c|}
\hline $\begin{array}{c}\text { (بالتعاون مع أو توقف) } \\
\text { ملحوظات }\end{array}$ & اسم البرنامج الذي تقدمه & التم المؤسسة \\
\hline في التسععينيات لكنه توقف. المؤسسة الإسلامية & ماجستير في التمويل الإسلامي، & $\begin{array}{r}\text { جامعة لفبرة } \\
\text { Loughborough ) } \\
\text { (University }\end{array}$ \\
\hline 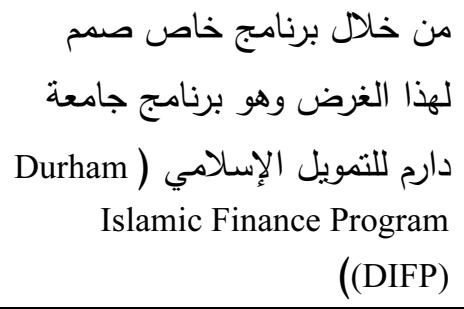 & 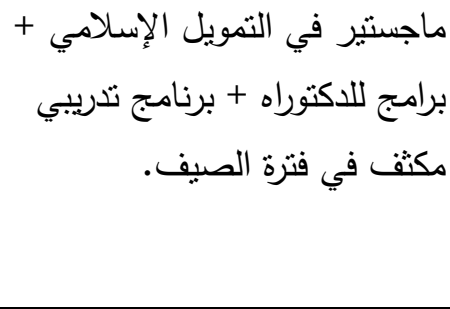 & $\begin{array}{r}\text { جامعة دارم } \\
\text { Durham ) } \\
\text { (University }\end{array}$ \\
\hline & 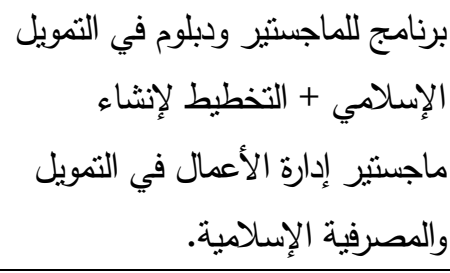 & $\begin{array}{r}\text { جامعة بانجور } \\
\text { Bangor ) } \\
\text { (University }\end{array}$ \\
\hline للجامعة البرنامج في الفرع التابع & التمويل والمصنير إدارة الأعمال في الإسلادية & $\begin{array}{l}\text { جامعة حي المال } \\
\text { (City Univesity) }\end{array}$ \\
\hline 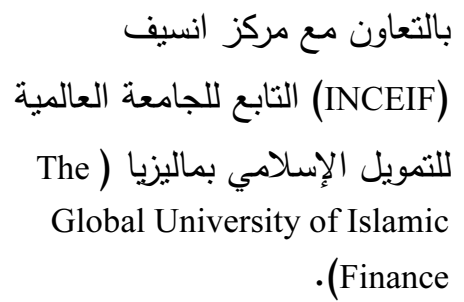 & والتمويل الإسلامير في الاستثمار المصرفي & $\begin{array}{r}\text { جامeة ريدينغ } \\
\text { Reading ) } \\
\text { (University }\end{array}$ \\
\hline $\begin{array}{l}\text { معهد تابع للمؤسسة الإسلامية } \\
\text { (The Islamic Foundation) }\end{array}$ & 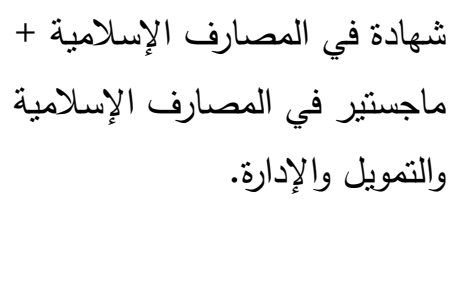 & $\begin{array}{r}\text { معهد ماركفيليد } \\
\text { للتعليم العاليي } \\
\text { Markfield ) } \\
\text { Institute for } \\
\text { Higher }\end{array}$ \\
\hline
\end{tabular}




\begin{tabular}{|c|c|c|}
\hline & & (Education \\
\hline & ماجستير إدارة الأعمال في & $\begin{array}{r}\text { جامعة أبردين في } \\
\text { Aberdeen ) } \\
\text { (University }\end{array}$ \\
\hline & ماجستير في التمويل والقانون & $\begin{array}{r}\text { جامعة نيوكاسل } \\
\text { Newcastle ) } \\
\text { (University }\end{array}$ \\
\hline النشاء مركز خاص تلابع لكلية إدارة & 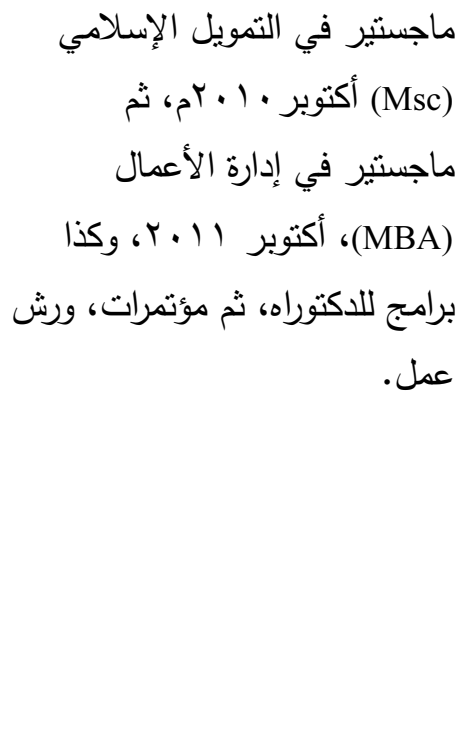 & 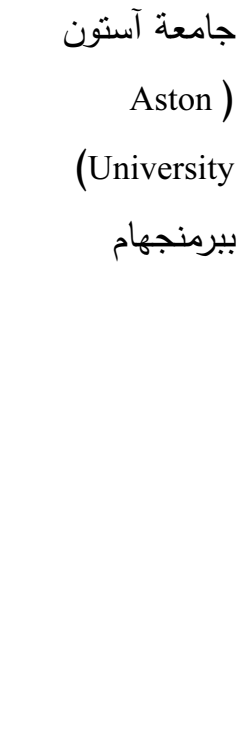 \\
\hline
\end{tabular}

وفيما يتعلق بالكراسي العلمية فإن جامعة دارم أنثأت واحدًا عام ^ . . بم، أما كلية الأعمال

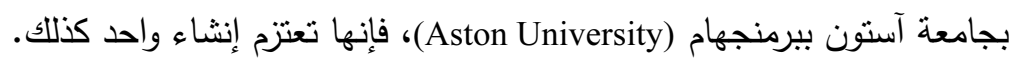




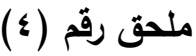

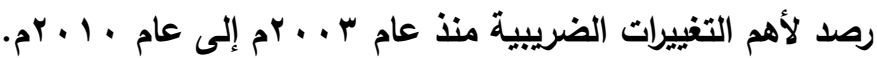

\begin{tabular}{|c|c|}
\hline التغيير الذي أدخل & 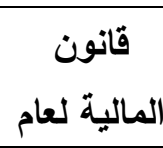 \\
\hline 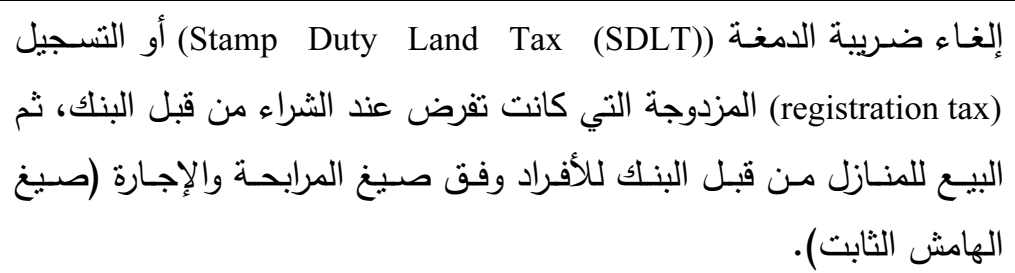 & r..r \\
\hline لونيع نطاق الصيخ ليشمل تلك القائمة على المشاركة مثل المشاركة المتتاقصة & o . o \\
\hline توسيع نطـاق الفئات المستقيدة وتمثل في الثـركات التـي ترغب في شـراء & 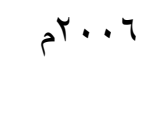 \\
\hline 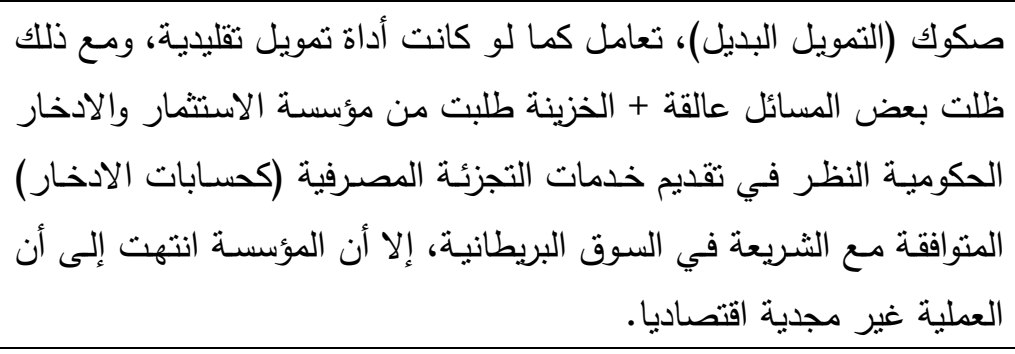 & $a^{r \cdots v}$ \\
\hline بعدم إصدارها في الوقت الرسائل المتعلقة بعملية إصدار الصكوك، والتوصل إلى قرار & م \\
\hline 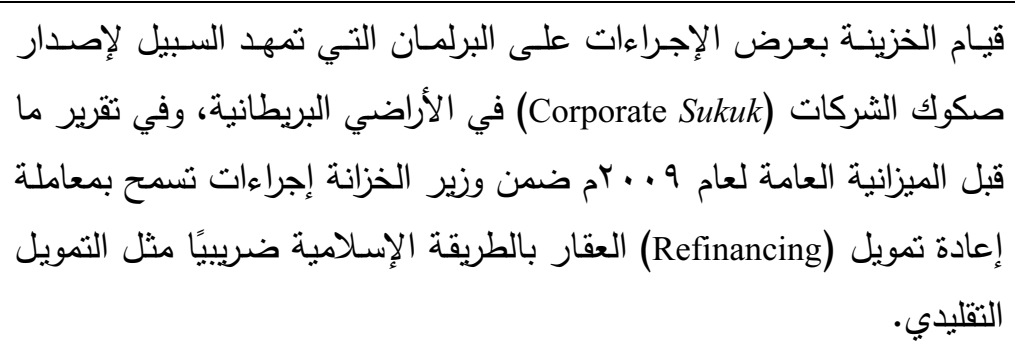 & $b^{r \cdots a}$ \\
\hline
\end{tabular}




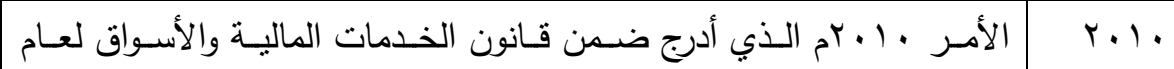

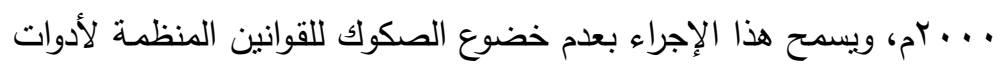
الاستثمار الجماعية (Collective Investment Scheme)، ومعاملتها كما لو كانـت أدوات ديـن تقليديـة تحــت مظلــة ســدات الاســثمار الماليـة البديلـة .(Alternative finance investment bonds (AFIBs) المصدر : www.ukinvest.gov.uk \& www.hm-treasury.gov.uk

يالاحظ مـن التغبيـرات السـابقة أنها مسـت قانون المالبة (Finance Act)، ولـم تطل قـانون المصـارف (Banking Act)، حيـث إن عملبـة ضـمان القبمـة الاسـمية للودائع (Deposits) بغض النظر عن استخداماتها سبسري مفعولها على المؤسسات التمويليـة التي تقدم هذا النوع من الخدمات. كما أن قانون المالبة ابتداء من عام

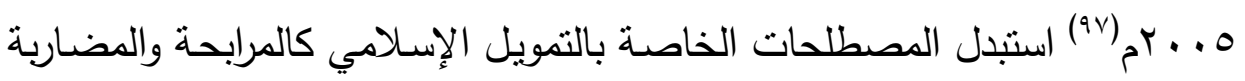
والصـكوك بمصـطلح التموبـل البـديل (Alternative financing)، وذلك لتلافي أبـة حساسية قد تتجم عن الموضوع؛ وللتحوط ربما من مطالبة اتباع الديانات الأخرى لمعاملة شبيمهة.

The Muslim Council of Britain (2009) "London and Islamic Finance: Briefing (9v) Paper for Mayor of London", p. 7. 


\title{
Islamic Finance in Britain: Opportunities and Challenges
}

\author{
Ahmed Belouafi $^{(1)}$ \& Abdelkader Chachi ${ }^{(2)}$ \\ ${ }^{1}$ Researcher, Islamic Economics Institute \\ King Abdul Aziz University, ${ }^{2}$ Economist Researcher \\ Islamic Research and Training Institute \\ IsDB group, Jeddah, Saudi Arabia \\ ambelouafi@kau.edu.sa achachi@isdb.org
}

Abstract. This article examines the opportunities and challenges of Islamic finance in the UK through official documents, reports from consultancy firms such as the International Financial Services London (IFSL), and academic studies which have focused on this matter. The article listed the most important obstacles that may impede the growth and development of Islamic finance in this country and enlisted some of the achievements attained by the authorities concerned to overcome these obstacles. On the other hand, the article identifies a number of opportunities that may be offered by the British market for Islamic finance.

The article concluded with a number of results which may benefit different entities; regulatory authorities in other countries, Islamic finance industry, as well as academia and research institutions whose programmes are enriched by the provision of practical examples of the reality of Islamic finance in different regions.

Keywords: Islamic Finance, Financial Supervision, Britain. 